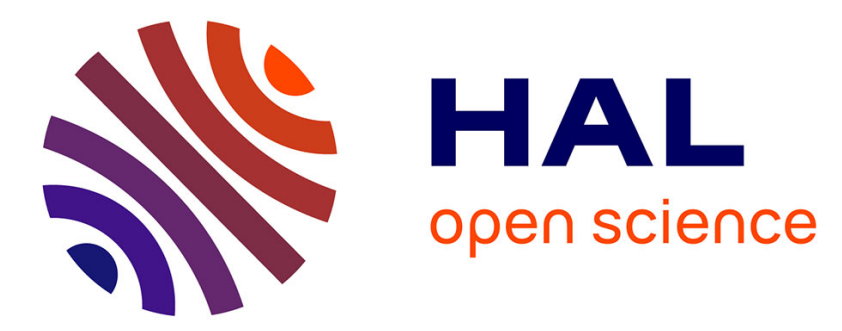

\title{
The Composition of the Lower Oceanic Crust in the Wadi Khafifah Section of the Southern Samail (Oman) Ophiolite
}

Jill A Vantongeren, P. B Kelemen, C. J Garrido, M. Godard, K. Hanghoj, M. Braun, J. A Pearce

\section{To cite this version:}

Jill A Vantongeren, P. B Kelemen, C. J Garrido, M. Godard, K. Hanghoj, et al.. The Composition of the Lower Oceanic Crust in the Wadi Khafifah Section of the Southern Samail (Oman) Ophiolite. Journal of Geophysical Research: Solid Earth, 2021, 126 (11), pp.e2021JB021986. 10.1029/2021JB021986 . hal-03452621

\section{HAL Id: hal-03452621 \\ https://hal.science/hal-03452621}

Submitted on 27 Nov 2021

HAL is a multi-disciplinary open access archive for the deposit and dissemination of scientific research documents, whether they are published or not. The documents may come from teaching and research institutions in France or abroad, or from public or private research centers.
L'archive ouverte pluridisciplinaire $\mathbf{H A L}$, est destinée au dépôt et à la diffusion de documents scientifiques de niveau recherche, publiés ou non, émanant des établissements d'enseignement et de recherche français ou étrangers, des laboratoires publics ou privés. 
${ }^{1}$ Department of Earth and Ocean Sciences, Tufts University

${ }^{2}$ Department of Earth and Environmental Sciences, Columbia University

$8{ }^{3}$ Instituto Andaluz de Ciencias de la Tierra, CSIC-UGR, Armilla, Granada, Spain

${ }^{4}$ Géosciences Montpellier, CNRS, Université de Montpellier, Montpellier, France

$10{ }^{5}$ British Geological Survey, UK

$11{ }^{6}$ Houston, TX

${ }^{7}$ School of Earth and Environmental Sciences, Cardiff University, Cardiff CF10 3AT

13

\section{The composition of the lower oceanic crust in the Wadi Khafifah section of the southern Samail (Oman) ophiolite}

\author{
J. A. VanTongeren ${ }^{1}$, P. B. Kelemen ${ }^{2}$, C. J. Garrido ${ }^{3,}$ M. Godard ${ }^{4,}$ K. Hanghoj ${ }^{5,}$ M. Braun ${ }^{6,}$ J.
} A. Pearce ${ }^{7}$ UK

Corresponding author: Jill VanTongeren (jill.vantongeren@tufts.edu)

\section{Key Points:}

- The intrusive oceanic crust is divided into lower gabbros and upper gabbros on the basis of incompatible trace element concentrations and mineral compositional variability

- The lower oceanic crust is accreted throughout in small sills of primitive melt

- The upper gabbros additionally receive the fractionated melts from the crystallization of the lower gabbros via melt migration.

\section{Plain Language Summary:}

The composition and structure of the oceanic crust is traditionally difficult to estimate u te to lack of exposure. Using rocks that crystallized from magmas at a submarine spreading center, we present major and trace element geochemical data for the entire lower oceanic crust. Our data shows how the lowermost sections of the oceanic crust are related to the uppermost intrusive and extrusive by crystallization and melt migration before and after eruptions. The bulk composition of our crustal section is in chemical equilibrium with the mantle and therefore represents a plausible primary mantle melt.

This article has been accepted for publication and undergone full peer review but has not been through the copyediting, typesetting, pagination and proofreading process, which may lead to differences between this version and the Version of Record. Please cite this article as doi: 10.1029/2021JB021986. 


\section{Abstract}

34 The composition of the intrusive gabbroic lower oceanic crust remains poorly characterized in

35 comparison to the extrusive portion of the oceanic crust, especially for intermediate-fast spreading mid-

36 ocean ridges. This is a consequence of limited exposures of extant lower oceanic crust or ophiolites

37 similar to mid-ocean ridge crust. One of the best analogues for mid-ocean ridge crust is the southern

38 Samail ophiolite that formed during a period of rapid seafloor spreading above a nascent subduction zone.

39 Here, we focus on the geochemical stratigraphy (whole rock and mineral major and trace element

40 compositions) of the 5200 m-thick, lower crustal, Wadi Khafifah section of the Wadin Tayin massif in the

41 southern Samail (Oman) ophiolite. Gabbros from the lowermost $3700 \mathrm{~m}$ of this section (the 'lower

42 gabbros') show no systematic changes in composition with height above the Mantle Transition Zone. In

43 contrast, gabbros from the uppermost $1500 \mathrm{~m}$ (the 'upper gabbros') display marked increases in

44 incompatible trace element concentration with increasing height. Liquids in equilibrium with the lower

45 gabbros have major and trace element compositions that overlap with those measured in the upper

46 gabbros and sheeted dikes. Upper gabbros preserve mineral cores with primitive major element

47 compositions that overlap with the range of lower gabbros; however, upper gabbro whole rock

48 compositions are significantly more enriched in incompatible trace elements relative to the lower gabbros.

49 Our data reveal that the upper gabbros are a composite of accumulated minerals derived from primitive

50 melts and a large fraction of evolved melts derived from the fractionation of the lower gabbros. We

51 propose a new "Full Sheeted Sills" model for the lower oceanic crust in which primitive magmas from the

52 mantle are emplaced throughout the lower crust and crystallized in situ. After diking events, evolved

53 magmas leave the lower gabbros and replenish the upper gabbros, thereby contributing to the higher

54 incompatible trace element budget in the upper gabbros relative to the lower gabbros. Our reconstructed

55 bulk compositions of the lower plutonic crust and the bulk oceanic crust from the Wadi Khafifah section

56 yield a plausible primary mantle-derived magma composition in equilibrium with depleted MORB

57 mantle.

This article is protected by copyright. All rights reserved. 


\section{Introduction}

59 It has long been known that mid-ocean ridge basalts (MORB) are not the direct result of mantle

60 melting, but rather have experienced crystal fractionation and magma mixing prior to eruption (see review

61 by Thompson, 1987 and references therein). Yet fundamental questions remain to be answered, notably

62 on where this fractionation occurs within the lower oceanic crust and upper mantle, what degree of

63 fractionation melts undergo, and how melt is extracted to feed the overlying dikes and lavas.

64 Crust generated at intermediate to fast-spreading mid-ocean ridges, is typically between 5-7 km

65 thick (> $5 \mathrm{~cm}$ per year, half-rate); only when spreading rates become ultra-slow (e.g. $<2 \mathrm{~cm}$ per year,

66 half-rate) do crustal thicknesses become significantly smaller (White and McKenzie, 1992; Chen, 1992;

67 Forsyth, 1993; Dick et al., 2003). The igneous stratigraphy of oceanic crust formed at intermediate - fast

68 spreading ridges is commonly subdivided into three distinct layers: a $\sim 4 \mathrm{~km}$ thick gabbroic lower section,

69 overlain by an $\sim 1 \mathrm{~km}$ thick sheeted dike complex, and then by a $\sim 1 \mathrm{~km}$ thick section of basaltic lava

70 erupted to the seafloor as pillow basalts and flows (Fig. 1). This type of 'layer-cake' stratigraphy is

71 commonly termed the "Penrose Structure" (Anonymous, 1972).

$72 \quad$ Although drilling into intact oceanic crust has provided innumerable insights into some portions

73 of the oceanic crust and upper mantle, no stratigraphically continuous core has so-far been recovered from

74 the seafloor to the mantle at an extant, intermediate- to fast-spreading mid-ocean ridge. In order to

75 address questions related to the compositional structure of the entire 5-7 km thick oceanic crust, we must

76 turn to ophiolites, where paleo-oceanic lithosphere has been obducted onto the continental crust. In some

77 cases, such as in the Samail (Oman) ophiolite, continuous exposure of the entire stratigraphic column

78 from the depleted mantle peridotite at the base of the crust to the basalts and marine sediments at the

79 paleo-seafloor is accessible.

80 Here we document the vertical stratigraphic variation in the composition of the gabbroic portion

81 of the Wadi Khafifah section in the Wadi Tayin massif of the southern Samail (Oman) ophiolite (Pallister

82 \& Hopson, 1981; Garrido et al., 2001; VanTongeren et al., 2008; VanTongeren et al., 2015). We present

83 bulk rock major element and trace element compositions together with in situ mineral major and trace

This article is protected by copyright. All rights reserved. 
84 element compositions throughout this $\sim 7.2 \mathrm{~km}$ thick section. The lower oceanic crust can be divided into

85 'lower gabbro' and 'upper gabbro' sections based on major and trace element geochemistry. The 'lower

86 gabbros' are characterized by cumulate gabbros with low incompatible trace element concentrations,

87 whereas the 'upper gabbros' contain a large proportion of zone crystals and interstitial material with high

88 incompatible trace element concentrations.

\section{Background}

90

912.1 Ophiolites and mid-ocean ridge crust

92 Few, if any, well-preserved ophiolites represent oceanic lithosphere formed at typical mid ocean

93 ridges. Typically, they have geochemical and geological features characteristic of magmas from supra-

94 subduction zone (SSZ) settings (Pearce et al., 1984) formed during the initial stages of subduction when

95 slab rollback creates an extensional tectonic environment inboard of the embryonic ocean trench (Stern

96 and Bloomer, 1992). Recent dredging and drilling in the Western Pacific have provided clues to how

97 rapidly spreading oceanic crust could still form in a subduction initiation setting. There, glasses recovered

98 via drilling and dredging close to a nascent trench have MORB-like compositions, some with no obvious

99 enrichment in fluid-mobile trace elements and their isotopes (Coulthard et a., 2021). With time, and

100 distance from the nascent trench, compositions evolve from MORB to depleted arc tholeiites and

101 boninites, producing oceanic crust and then a protoarc edifice. Dating has revealed that subduction

102 initiation in the Western Pacific was followed by c. 2 Myr. of intermediate-rate sea-floor spreading with

103 the earliest oceanic crust having MORB-like compositions (Reagan et al., 2019). Although the cause of

104 extension is different (local slab rollback rather than distal slab pull), the process of crustal accretion is

105 similar at normal mid-ocean ridges and nascent subduction settings.

106 Many subduction initiation features are locally present in the Samail ophiolite, notably the

107 boninite and depleted tholeiite magmas that intruded into, and erupted upon, the main 'Penrose'

108 stratigraphy in the northern part of the Samail ophiolite (e.g. Alabaster et al., 1982; Ishikawa et al., 2002).

This article is protected by copyright. All rights reserved. 
109 However, most of these complicating factors are of minor significance in the southern part of the

110 ophiolite, the site of this study. Indeed, the "Penrose model" crustal section is based largely on the

111 equivalence between seismic observations of Pacific crust and geological observations of lithological

112 layering in the Samail ophiolite (e.g., Christensen \& Smewing, 1981).

113 Two tectonically exposed sections of the fast-spreading East Pacific Rise (EPR) gabbroic crust

114 have been studied in detail: Hess Deep and Pito Deep. Pito Deep exposes 300-700 m of upper gabbro

115 (Perk et al., 2007; Brown et al., 2019) and is not directly comparable to the Khafifah section presented

116 here. Hess Deep exposes an extensive section of layered and isotropic gabbro comparable to the Khafifah

117 section, though there are uncertainties associated with the structural integrity of the section that has been

118 drilled (e.g. Ferrini et al., 2013).

119 At Hess Deep, Natland and Dick (1996), Lissenberg et al. (2013) and Gillis et al. (2014)

120 document the presence of primitive gabbro with similar clinopyroxene Mg\# and An content to that

121 observed in the lower gabbros in our samples (Fig. 3). Though Khafifah plagioclase falls among the

122 highest An contents at a given clinopyroxene Mg\# in gabbroic samples from Hess Deep (Fig. 3), the

123 broad overlap in range gives further evidence that processes forming the lower crust of the Oman

124 ophiolite were similar to those at modern-day, fast-spreading ridges. Note that both the Khafifah and Hess

125 Deep mineral compositions have higher plagioclase An at a given clinopyroxene Mg\# than samples from

126 other mid-ocean ridge sections, including Pito Deep from the EPR. Thus, while all ophiolites (including

127 the Samail) have mineral and lava compositions that differ systematically from mid-ocean ridge samples,

128 with some geochemical characteristics of volcanic arc or supra-subduction zone magmas (Miyashiro,

129 1975; Pearce et al., 1984; Dilek and Furnes, 2014), samples from the southern massifs of the Samail

130 ophiolite (the Samail Massif and the Wadi Tayin massif; Fig. 2) are more similar to mid-ocean ridge

131 lithologies than samples from any other well-studied ophiolite worldwide (e.g., Macleod et al., 2013).

132

133

\section{$134 \quad 2.2$ The Oman Ophiolite}

This article is protected by copyright. All rights reserved. 
136 preserved ophiolite on Earth, formed at a fast-spreading submarine spreading center (Tilton et al., 1981;

137 Rioux et al., 2012; Coleman, 2012; Coleman \& Hopson, 1981). The ophiolite is divided into three

138 distinct domains, the northern, central and southern (Nicolas et al., 2000; Fig. 2). Each domain displays a

139 more-or-less continuous Penrose-type stratigraphy of harzburgitic mantle, overlain by gabbros, sheeted

140 dikes, and pillow basalts (Anonymous, 1972). The thicknesses of each unit, however, vary considerably

141 from north to south (Nicolas et al., 2000).

142 Basalt compositions from the two southernmost massifs of the ophiolite, the Samail and Wadi

143 Tayin blocks (Fig. 2), are from the Geotimes lava unit (Alabaster et al., 1982), also termed V1 (Ernewein

144 et al., 1988), which has major and trace element characteristics that reveal a near MORB-like composition

145 with a minor subduction zone signature (Pearce \& Peate, 1995; McLeod et al., 2013). As noted in the

146 previous section, its nearest analogues are the fore-arc basalts (FAB) of the Western Pacific that mark

147 spreading following subduction initiation (Reagan et al., 2010; Shervais et al., 1999). It is more similar to

148 MORB than the Lasail and Alley (V2) lava units that overlie the Geotimes/V1 lavas in the northern

149 ophiolite massifs and include boninites (Alabaster et al., 1982; Pallister \& Knight 1981; Godard et al.,

150 2006; Ishikawa et al., 2002). Similarly, lower crustal gabbros in the Wadi Tayin and Samail massifs

151 mostly record crystallization of olivine (ol), plagioclase (plag) and clinopyroxene (cpx), typical of

152 cumulates derived from fractional crystallization of tholeiitic basalts such as MORB magmas, followed

153 by extraction of the remaining evolved melt. These gabbros are unlike abundant low calcium pyroxene

154 (orthopyroxene, opx) bearing cumulates - websterites and gabbronorites - that form significant

155 proportions of the igneous crust in the northern massifs, although small intrusions of primitive (Mg\#, or

156 molar $\mathrm{Mg} /(\mathrm{Mg}+\mathrm{Fe})>0.8)$, opx-bearing cumulates are present in the Samail and Wadi Tayin mantle

157 sections (e.g., Kelemen et al., 1997; Kelemen et al., 2020; and our unpublished mapping). Primitive opx-

158 bearing cumulates record the initial stages of crystallization of mantle-derived magnesian andesites, such

159 as boninites, which are found within some forearcs, volcanic arcs and upper lavas in the northern massifs,

160 but are not found in the southern massifs. Nonetheless, the higher plagioclase anorthite content at a given

This article is protected by copyright. All rights reserved. 
161 clinopyroxene Mg\# in Samail and Wadi Tayin massif gabbros relative to mid-ocean ridges (Fig. 3) may

162 be indicative of stabilization of An-rich felspar in magmas with water contents at the upper end of the

163 MORB spectrum. Hornblende gabbros are present just below the sheeted dikes in some Wadi Tayin

164 crustal sections (Pallister \& Hopson, 1981; Garrido et al., 2001), similar to gabbros from the sheeted dike-

165 gabbro transition in other mid-ocean ridge samples (Alt et al., 2007 ; Koepke et al., 2011; Gillis et al., 166 1996).

167 The mantle section of the Samail and Wadi Tayin massifs records major and trace element

168 mineral compositions (Godard et al., 2000; Monnier et al., 2006; Hanghøj et al., 2010) similar to those of

169 peridotites dredged and drilled at mid-ocean ridges (Johnson et al. 1990; Bodinier \& Godard, 2003; Niu,

170 2004). Spinel $\mathrm{Cr} \#($ molar $\mathrm{Cr} /(\mathrm{Cr}+\mathrm{Al}))$ spans a range from 35 to 70 , extending to values that are just

171 slightly higher values than spinels from mid-ocean ridges (10 to 65 , with one of $\sim 1100$ values at $\mathrm{Cr} \# 70$;

172 e.g., Urann et al., 2020). Again, these are unlike spinels from the northern massifs of the Samail

173 ophiolite, which extend to Cr\#'s as high as 81 (e.g., Rollinson, 2005), as do chromites from many supra-

174 subudction zone settings, and from many ophiolites worldwide.

175

$176 \quad 2.3$ Field work and sampling

177 All lower crust samples analyzed for this study were collected from the Wadi Khafifah section,

178 first described in detail by Pallister and Hopson (1981), in the Wadi Tayin massif (Fig. 2). The Wadi

179 Khafifah section was selected based on the lack of high-offset faulting or shear zones within the lower

180 crustal section. It is located approximately $10 \mathrm{~km}$ to the west of Wadi Gideah, which has been

181 extensively studied by Müller (2016) and is the site of gabbro holes GT1 and GT2 of the Oman Drilling

182 Project (Fig. 2).

183 Stratigraphic depths for gabbroic samples were determined according to the strike and dip of the

184 rock with the paleo-mantle-crust transition zone (MTZ) as $0 \mathrm{~m}$ (see Garrido et al., 2000). The preserved

185 crustal section in this area is $6 \mathrm{~km}$ thick, made up of gabbros and sheeted dikes, but excluding the upper

186 pillow basalt layer, which is not preserved. A total crustal thickness of $7.2 \mathrm{~km}$ is estimated for the Wadi

This article is protected by copyright. All rights reserved. 
187 Khafifah section, which includes an estimated $1.5 \mathrm{~km}$ of sheeted dikes $(0.8 \mathrm{~km}$ of which is preserved), an 188 estimated $0.5 \mathrm{~km}$ of pillow basalt, and $5.2 \mathrm{~km}$ of gabbroic lower crust. The $5.2 \mathrm{~km}$ gabbroic portion is 189 further subdivided into an $\sim 4.2 \mathrm{~km}$-thick "layered gabbro" section (see Fig. 4a for photos), a $\sim 0.5 \mathrm{~km}$ 190 hick "transitional gabbro" section, and finally a $\sim 0.5$ km-thick "high-level gabbro" section (Fig. 1; e.g.

191 Pallister and Hopson, 1981; Pallister and Gregory, 1983). The "transitional gabbro" and "high-level

192 gabbros" are referred to as 'foliated gabbros' and 'varitextured gabbros' by Macleod and Yaouancq (2000)

193 in other sections of the ophiolite (see also Koepke et al., 2011, France et al., 2009; France et al., 2013;

194 Nicolas et al., 2008).

195 In the terminology of Pallister and Hopson (1981), the 'transitional gabbros' are defined as

196 planar-laminated, but not macroscopically layered, cpx-gabbro and ol-cpx gabbro; whereas the 'high-

197 level gabbros' are defined as isotropic hornblende-clinopyroxene-gabbros with minor olivine-hornblende-

198 clinopyroxene-gabbro. The two units commonly grade into one another, and in some cases the

199 transitional gabbro section is absent entirely. For the Khafifah section, Pallister and Hopson (1981) place

200 the base of the transitional gabbro section at $4200 \mathrm{~m}$ above the Mantle Transition Zone and the base of the 201 high-level gabbro section at $\sim 4700 \mathrm{~m}$.

202 Our whole rock and mineral incompatible trace element data (see Results below) from Wadi 203 Khafifah show that there is a distinct compositional break at $3700 \mathrm{~m}$ above the MTZ, approximately 500 $204 \mathrm{~m}$ below the base of the 'transitional gabbro' section of Pallister and Hopson (1981). Furthermore, the 205 location of this compositional boundary is nearly coincident with a distinctive change in plagioclase 206 lattice preferred orientation (e.g. VanTongeren et al., 2015). At approximately 3300m-3600 m above the 207 MTZ, plagioclase b-axis maxima transition from Moho perpendicular in the lower gabbros to nearly 208 parallel in the upper gabbros (e.g. elongate plagioclase grains align horizontally with long-axis (a-axis) 209 parallel to the Moho in the lower gabbros vs. vertically in the upper gabbros; VanTongeren et al., 2015). 210 The stratigraphic coincidence of the major change in the mineral-scale orientiation (e.g., VanTongeren et 211 al., 2015) with the major change in whole rock incompatible trace element concentration (this study), 
212 gives confidence that there is a fundamental shift in the nature of the magmatic system occuring in the 213 lower crust at approximately $3700 \mathrm{~m}$ above the MTZ in the Wadi Khafiah section.

214 We therefore designate two distinct layers in the gabbroic lower crust: (1) the 'lower Gabbros'

215 corresponding to stratigraphic heights from 0-3700 m above the MTZ, and (2) the 'upper gabbros',

216 corresponding to stratigraphic heights from $3700-5200 \mathrm{~m}$ above the MTZ. Grouping the uppermost

$2171500 \mathrm{~m}$ of the gabbroic section into a single 'upper gabbro' unit is preferable to avoid confusion based on

218 gradual, or sometimes absent, field-based distinctions.

219

\section{Materials and Methods}

223 outcrops of the 'upper gabbros' in this section suffer from pervasive weathering making detailed sampling

224 of these sections impossible. We sampled only exceptionally fresh outcrops, which reduces the total 225 number of samples for the upper gabbros, but allows us to truly evaluate igneous processes from whole 226 rock and mineral compositions. All gabbro samples measured here are exceptionally fresh and largely 227 free of low temperature alteration or metasomatism (Fig. 4).

228 Sheeted dike samples were collected from a similar location to those studied by Pallister and 229 Hopson (1981)(Table 1b). All 33 sheeted dike samples reported here are slightly to moderately altered at 230 greenschist facies, but preserve chilled margin contacts and provide reliable compositions for comparision 231 here for all but the more fluid-mobile elements.

\section{3. 1 Compositional Analyses}

234 We report data from 33 lower crustal samples spaced on average every 50-100 m through the 235 lower crust stratigraphy, except for a stratigraphic sampling gap occurring between $2369 \mathrm{~m}$ and $2999 \mathrm{~m}$. 236 Whole rock major element compositions for gabbro and sheeted dikes lithologies were determined by 
237 XRF at the Washington State Geoanalytical Laboratory (Table 2). Trace element concentrations were

238 determined by Inductively Coupled Plasma Mass Spectrometry (ICPMS) at the Université de Montpellier

239 (the gabbros) and Cardiff University (the dikes).

240 Compositions of the major rock forming minerals were determined by electron microprobe

241 analysis (EPMA) at the Massachusetts Institute of Technology JEOL EPMA facility and the American

242 Museum of Natural History Cameca EPMA facility. Major and minor elements in pyroxenes (Table 3)

243 and olivines (Table 4) were analyzed with $20 \mathrm{nA}, 15 \mathrm{KeV}$ beam, and $30 \mathrm{sec}$ on peak and $15 \mathrm{sec}$ on

244 background. Major and minor elements in plagioclase (Table 5) were analyzed with a 10nA, $15 \mathrm{keV}$

245 beam with $30 \mathrm{sec}$ on peak and $15 \mathrm{sec}$ on background. Modal abundances of minerals were determined by

246 the least squares method using the major element compositions of the whole rock and its consituent

247 minerals. This method does not distinguish between cumulus and intercumulus mineral abundances.

248 Trace element concentrations of plagioclase (Table 6) and clinopyroxene (Table 7) were

249 measured by Laser Ablation ICPMS (LA-ICPMS) at Rutgers University. For plagioclase, we used a spot

250 size of 65 microns and a fluence of $5.32 \mathrm{~J} / \mathrm{cm}^{2}$. For pyroxene, we used a spot size of 40 microns and

251 fluence of $2.95 \mathrm{~J} / \mathrm{cm}^{2}$. Standards NIST 610, 612, and 614 were used to construct calibration curves, and

252 basalt glasses BCR and BIR were regularly analyzed as unknowns to ensure accuracy. All data presented

253 represent averages of mineral cores. No mineral rims were measured in this study.

\section{Results}

255

256 4. 1 Bulk rock compositions

257 The modal mineralogy for each sample from the Wadi Khafifah lower crustal section is provided

258 in Table 1. In the lowermost portion of the gabbroic section (0-3700 m above the Mantle Transition

259 Zone), hereafter referred to as the 'lower gabbros', there are small-scale changes in modal proportions of

260 minerals due to magmatic layering. However, the typical gabbroic modal abundance of 50-55\%

261 plagioclase, 35-40\% clinopyroxene, and 5-10\% olivine is roughly constant throughout the lower gabbro

This article is protected by copyright. All rights reserved. 
262 section (Table 1). In contrast, the uppermost $1500 \mathrm{~m}$ of the gabbro section (3700-5200 m), the 'upper 263 gabbros', lack olivine and instead Fe-Ti oxides and amphibole become more common phases (Table 1). 264 Whole rock major and trace element compositions for each sample are provided in Table 2. In 265 the lower gabbros, whole rock $\mathrm{Mg} \#$ is in the range of $80.2 \pm 3$ and $\mathrm{MgO}$ wt $\%$ has an average of $11.6 \pm 2.3$

266 wt\% with no systematic variation with increasing height above the mantle-crust transition zone (MTZ).

267 Above $3700 \mathrm{~m}$, in the upper gabbros, whole rock Mg\# decreases from 82 to 46; and the whole rock

$268 \mathrm{MgO}$ content decreases from $\sim 12 \mathrm{wt} \%$ to $5 \mathrm{wt} \%$ at the top of the section (Fig. 5).

269 Incompatible (bulk partition coefficient $\mathrm{D}<1$ ) trace elements show a similar change in character

270 at the lower gabbro-upper gabbro transition, i.e., at $3700 \mathrm{~m}$ above the MTZ (Fig. 6). Whole rock Sr, Zr,

271 Y and middle to heavy rare earth element (REE) contents are low and approximately constant through the

272 stratigraphy in the lower gabbros, whereas the upper gabbros show systematic increases in these trace

273 element contents with increasing height above the MTZ. Whole rock P and light REE concentrations

274 show a scattered but significant increase with height in the lower gabbros, followed by a much more

275 marked increase with height in the upper gabbros.

276 In contrast to the whole rock major elements and incompatible trace elements, compatible (bulk

277 D > 1) trace elements show no systematic change with increasing stratigraphic height throughout the

278 entire lower crustal section, including in the upper gabbros (Fig. 6).

279 The paucity of fresh, unaltered outcrops of pillow lava from the Wadi Tayin massif limits our

280 ability to compare the lower crustal gabbros to the lavas in this section. Lava samples from the massifs

281 further to the north and west have been analyzed by Godard et al. (2003), Godard et al. (2006), and

282 Macleod et al. (2013), but these have experienced extensive prehnite-pumpellyite facies metamorphism

283 and their compositions, particularly of fluid-mobile elements, cannot be reliably related to the gabbro

284 stratigraphy. Sheeted dike samples from Wadi Khafifah, while subject to some greenschist facies

285 metamorphism, have preserved chilled margins and compositions that are less altered. Additionally,

286 Kelemen et al. (2020) showed that the sheeted dikes and V1 lavas from throughout the ophiolite have

287 indistinguishable compositional ranges for fluid immobile elements. Results from IODP drill cores along

This article is protected by copyright. All rights reserved. 
288 the East Pacific Rise also show indistinguishable compositions for the sheeted dikes and pillow lavas (see

289 data from Teagle et al., 2006 and Umino et al., 2008). For this reason, we consider the compositions of

290 sheeted dike samples from Wadi Khafifah presented here to best represent extrusive volcanism for

291 comparison with the lower crustal gabbro section.

292 The major and trace element compositions of sheeted dikes (and V1 lavas) range from those

293 similar to the upper gabbros to others that are distinctly more evolved. The continuous nature of the

294 compositional evolution from upper gabbros to sheeted dikes suggests that these units are likely related

295 by crystal fractionation (Fig. 5, 6).

\section{2 Mineral major and trace elements}

Average major element concentrations for plagioclase, clinopyroxene, and olivine throughout the

300 gabbroic section (Tables 3 - 5) show no systematic trends with stratigraphic height in the gabbros (Fig.

301 7). Clinopyroxene Mg\# varies unsystematically from 88 to 78; plagioclase An content varies from An88

302 to 72; and olivine varies from Fo85 to 75. Only one sample, near the top of the upper gabbro section, has

303 mineral core compositions significantly more evolved than the majority of the lower crust. Sample

304 OM97-209, approximately $4468 \mathrm{~m}$ above the MTZ, has average plagioclase An47 and clinopyroxene

$305 \mathrm{Mg} \#$ of 73. This sample also contains a large portion of magmatic amphibole (Table 1).

306 Despite the lack of systematic variation with height, olivine Fo content and clinopyroxene Mg\# in

307 the Khafifah data are strongly correlated, while plagioclase An is weakly but significantly correlated with

$308 \mathrm{Mg} / \mathrm{Fe}$ in both olivine and clinopyroxene.

309 In situ trace element concentrations for plagioclase and clinopyroxene in the gabbroic samples are

310 presented in Tables 6 and 7, respectively. Average concentrations of compatible trace elements, such as

$311 \mathrm{Cr}$ and Sc in clinopyroxene and $\mathrm{Sr}$ in plagioclase, do not change systematically with height above the

312 MTZ in the lower gabbros, and do not change appreciably between the lower gabbros and upper gabbros

313 (Fig. 8). Average incompatible trace elements, however, do show systematic increases in concentration

This article is protected by copyright. All rights reserved. 
314 from the lower to the upper gabbros. $\mathrm{Zr}$ in clinopyroxene increases from 4-6 ppm near the base of the

315 crust to $\sim 10 \mathrm{ppm}$ at the lower gabbro-upper gabbro transition, with one outlier at $14 \mathrm{ppm}$ just below this

316 level (Fig. 8), but return to lower values of $\sim 6 \mathrm{ppm}$ in the upper gabbros. In clinopyroxene, $\mathrm{Zr}$

317 concentrations correlate strongly with other highly incompatible elements (including light REE) but not

318 with less incompatible trace elements such as the middle to heavy REE. Clinopyroxene Mg\# is weakly

319 but significantly, negatively correlated with clinopyroxene $\mathrm{Zr}$ and LREE contents, but not with more

320 mobile trace element concentrations, e.g., Sr and Ba.

321 Similarly to $\mathrm{Zr}$ in clinopyroxene, Ce in plagioclase (chosen due to its relatively high

322 concentration compared with other REE and incompatible trace elements) exhibits a systematic increase

323 with height above the MTZ. Plagioclase in samples from near the base of the crust contains

324 approximately $0.3 \mathrm{ppm}$ Ce. Ce concentration in plagioclase gradually increases to $\sim 0.65 \mathrm{ppm}$ at the top

325 of the lower gabbro section (Fig. 8), before returning to lower values of $\sim 0.38 \mathrm{ppm}$ in the uppermost

326 gabbro sample. Plagioclase and clinopyroxene REE are well-correlated.

327 These observations for the Wadi Khafifah section are similar to those made by Korenaga and

328 Kelemen (1998) in the Wadi Al Abyad section of the Nakhl massif, about $100 \mathrm{~km}$ northeast of the

329 Khafifah section. Using the data of Browning (1982), Korenaga and Kelemen a noted a similar lack of

330 correlation between stratigraphic height and olivine Fo or clinopyroxene Mg\#. Additionally, despite

331 well-correlated elemental compositions within and between minerals, they did not observe any systematic

332 variation with stratigraphic height in compatible trace element concentrations or elemental ratios.

333

\section{Discussion}

\section{5}

\section{5. 1 Compositional stratigraphy in the lower oceanic crust}

337 In the lower gabbros, there is a lack of systematic compositional variation with stratigraphic

338 height for most elements and element ratios (Figs. 5-8). While mineral compositions are variable, they

This article is protected by copyright. All rights reserved. 
339 remain in a narrow range throughout the entire $3700 \mathrm{~m}$ of the lower gabbroic crust (Fig. 7, 8). Above

$340 \sim 3700 \mathrm{~m}$ in our section, a major compositional break marks the geochemical transition to the upper

341 gabbroic section. Olivine no longer appears as a cumulus mineral phase, and instead Fe-Ti oxides and

342 amphibole become more common phases. Whole rock incompatible trace element concentrations

343 increase dramatically above this level (Fig. 6). In the whole rocks, the concentration of trace elements

344 typically compatible in clinopyroxene and olivine (e.g., $\mathrm{Cr}$ and Ni) decrease markedly, while

345 concentrations of elements typically compatible in plagioclase (e.g. Sr) increase (Fig. 6). Despite this

346 change in whole rock compositions, mineral cores have major element and compatible trace element

347 compositions that do not appear to change at this level (Fig. 7, 8). The Mg\# of clinopyroxene and An

348 content of plagioclase cores stay within the range of the layered gabbros until the uppermost two samples

349 in our section, starting at $\sim 4500 \mathrm{~m}$. This observation is similar to that made by Pallister and Hopson

350 (1981), who showed that the mineral cores stayed the same through the transitional gabbros, but the rims

351 became highly evolved.

352 The compositional break at approximately $3700 \mathrm{~m}$ can be explained by the transition from rocks

353 dominated by cumulate minerals in the lower gabbros, from which melt was efficiently extracted in an

354 open system, to rocks that may have undergone closed system crystallization in the upper gabbros,

355 including solidification of some proportion of low temperature, evolved melt that was never extracted.

356 Closed system crystallization is often described in terms of "trapped melt" (Barnes et al., 1986; Ross and

357 Elthon, 1997; Borghini and Rampone, 2007), however, this concept is somewhat fraught given that there

358 is no melt remaining in the rocks today. Instead, geochemical enrichment likely manifests in the

359 formation of evolved rims in zoned crystals (e.g. Pallister and Hopson, 1981; Lissenberg et al., 2013), or

360 grain boundary material rich in incompatible elements.

361 To quantify the difference in incompatible element enrichment between the lower gabbros and

362 upper gabbros, we can turn to highly incompatible trace elements (e.g., bulk partition coefficient $=\mathrm{D}<<$

363 1) such as $\mathrm{Zr}$ in the whole rock. An enrichment factor, $E$, is calculated as:

This article is protected by copyright. All rights reserved. 
367 Because the magma originally in equilibrium with the cumulate assemblage is now gone, we must assume 368 a parent magma composition appropriate for a mid-ocean ridge setting. A regression of $\mathrm{Mg \#}$ vs ppm $\mathrm{Zr}$ in 369 MORB glasses from the EPR (from PetDB; https://search.earthchem.org/) yields $40 \mathrm{ppm} \mathrm{Zr}$ at an Mg\# 370 of 70, appropriate for a primitive, mantle-derived, low $\mathrm{fO}_{2}$ basalt (for samples from the Mid-Atlantic 371 Ridge, MAR, a simple regression yields slightly higher, $48 \mathrm{ppm}, \mathrm{Zr}$ at $\mathrm{Mg \#} \mathrm{70).} \mathrm{Following} \mathrm{equation} 1$,

372 the lower gabbros in our section have an enrichment factor of 5-10; whereas the upper gabbros have 373 significantly higher E, up to 80 (Fig. 9a; Table 2). There is a slight increase in E in the lower gabbros just 374 prior to the transition to the upper gabbros, with some samples reaching 15-20 (Fig. 9a).

375 While it is impossible to know the precise $\mathrm{Zr}$ concentrations in the original Khafifah parent 376 magmas, adjusting this value will not change the observed distinction between the lower gabbros and 377 upper gabbros in our study. For example, slightly higher enrichment factors (10-20 in the lower gabbros 378 and 40-70 in the upper gabbros) are calculated using $\mathrm{P}_{2} \mathrm{O}_{5}$ as the highly incompatible element in the 379 calculations (regression of $\mathrm{Mg} \#$ vs wt $\% \mathrm{P}_{2} \mathrm{O}_{5}$ for EPR MORB glasses yields $\sim 0.085 \mathrm{wt} \% \mathrm{P}_{2} \mathrm{O}_{5}$ at an $\mathrm{Mg \#}$ 38070 [MAR, $1.0 \mathrm{wt} \% \mathrm{P}_{2} \mathrm{O}_{5}$ at $\mathrm{Mg} \#$ 70] (Fig. 9b). Another way to estimate the proportion of incompatible trace element enrichment present along 382 grain boundaries or as thin, evolved rims of crystals is to compare the measured whole rock composition 383 to a reconstructed whole rock composition calculated from modal abundances of minerals and in situ 384 mineral compositions (not including rims within 50 microns of grain boundaries, which we did not 385 analyze):

387 Whole Rock calculated $=\left[\left(X_{i}^{c p x} \times\right.\right.$ Mode $\left.\left.^{c p x}\right)+\left(X_{i}^{\text {plag }} \times M o d e^{\text {plag }}\right)\right] / 100 \quad$ eqn. 2

388 Enrichment $=$ Whole Rock calculated - Whole Rock $_{\text {measured }} /$ Whole Rock measured $_{\text {eqn. } 3}$ 
389 For our calculations, we assume that the incompatible trace element contents of olivine are negligible.

390 Due to the low incompatible trace element abundances typically measured in olivine and the low modal

391 abundance of olivine in our section, these assumptions do not affect the results for most elements

392 considered here.

393 The enrichment between measured and calculated whole rock compositions (eqn. 3; Suppl. Table

394 1) increases from the lower gabbros to the upper gabbros for all incompatible trace elements (Fig. 10).

395 This is consistent with previous observations that mineral core compositions are similar in upper and

396 lower gabbros, while mineral rims are significantly more evolved and compositional zoning becomes

397 more pronounced in the upper gabbros from W. Khafifah (Pallister and Hopson, 1981), Wadi Al Abyad

398 (MacLeod and Yaouancq, 2000; Lissenberg and MacLeod, 2016) and Hess Deep (Lissenberg et al.,

399 2013).

400

4015.2 Formation of the Upper Gabbros

402 The lack of systematic variation in major and compatible trace element compositions of minerals

403 and whole rocks (Figs. 5-8) and low extents of core-rim zoning (Fig. 10) over $3700 \mathrm{~m}$ of stratigraphy in

404 the lower gabbros from W. Khafifah, provide evidence that the evolved melt was efficiently extracted

405 following initial crystallization of the lower gabbros. To estimate the composition of this extracted liquid,

406 we calculate the REE concentration of liquids in equilibrium with clinopyroxene from the lower gabbros

407 using the mineral-melt partition coefficients of Wood and Blundy (1997)(Table 8) and the Fe/Mg ratio of

408 liquids in equilibrium with lower gabbro olivine using the $\mathrm{Fe} / \mathrm{Mg} \mathrm{K} \mathrm{D}_{\mathrm{D}}=0.3$ from Roeder and Emslie

409 (1970). Figure 11 shows that the compositions of calculated liquids in equilibrium with the lower

410 gabbros overlap the whole rock compositions of the upper gabbros and the most depleted sheeted dike

411 compositions in our section. Thus, it is likely that upper gabbros and overlying extrusive upper crust

412 contain the expelled liquid fraction from the lower gabbros.

413 On the basis of compiled data on whole rock REE concentrations, Kelemen et al. (1997b),

414 proposed that the upper gabbros represent the liquids expelled from the lower gabbros, and represent their

This article is protected by copyright. All rights reserved. 
415 so-called 'compositional conjugate'. Our new dataset, however, shows that this interpretation cannot be

416 entirely correct. The whole rock compositions of the upper gabbros have prominent Eu anomalies (Fig.

417 12), indicating that they are not themselves "frozen liquids", but instead contain a component of cumulate

418 plagioclase (and clinopyroxene) that crystallized from an evolving melt, some of which was later

419 extracted. Mineral cores in the upper gabbros have major and compatible trace element concentrations

420 similar to their counterparts in the lower gabbros (Fig. 7-8), and requires that they initially crystallized

421 from similar, primitive parent magmas to the lower gabbros. However, four lines of evidence show that,

422 in addition to accumulated plagioclase and clinopyroxene, the upper gabbros host a significant fraction of

423 the evolved melt component expelled after crystallization of the lower gabbros: (1) clear evidence of

424 mineral zoning and grain boundary enrichment in the upper gabbros (Fig. 10), (2) a change in the textural

425 character of the lower gabbros compared with the upper gabbros (e.g., Fig. 4), (2) markedly higher whole

426 rock incompatible trace element concentrations in upper gabbros relative to lower gabbros (Fig. 5, 6), and

427 (3) the similarity in whole rock composition of the upper gabbros to equilibrium liquids from the lower

428 gabbros (Fig. 11, and Kelemen et al. 1997b).

429

$430 \quad 5.3$ How is melt extracted from the lower crust?

431 With regards to the mechanism of melt extraction from the lower gabbros to the upper gabbros, 432 three end-member possibilities exist: (1) periodic fracturing and extraction in dikes (e.g. Kelemen and 433 Aharanov, 1998), (2) compaction and porous flow (Quick and Denlinger, 1993; Coogan et al., 2000), or

434 (3) focused, reactive flow in anorthosite channels (Kelemen \& Aharonov, 1998; Morales et al., 2011).

435 Variations in, and combinations of, these options are also possible (e.g. Macleod et al., 2007; Lissenberg 436 and Dick, 2008; Lissenberg et al., 2009).

437 Periodic fracturing and tapping of magma from crustal melt lenses was proposed by Korenaga 438 and Kelemen (1997) and Kelemen et al. (1997) in their studies of gabbro lenses in the Mantle Transition 439 Zone in the Samail ophiolite. These studies showed that MTZ gabbros had similar compositions, 440 layering, and textures to those found in the overlying lower gabbros. They noted that the MTZ gabbros

This article is protected by copyright. All rights reserved. 
441 were near-perfect adcumulates that had lost a significant fraction of evolved melt (e.g. Fig. 4). Moreover,

442 Korenaga \& Kelemen (1998) showed that the nature of compositional layering in lower crustal gabbros -

443 poorly correlated with depth in the crust, but with strong element-element and mineral-mineral

444 compositional correlations - is inconsistent with reactive porous flow of the bulk of the crust-forming

445 magma through the crystal matrix near the base of the crust. Thus, most of the melt must be extracted

446 from lower gabbros in focused conduits, rather than by diffuse porous flow. A mechanism of magmatic

447 fracturing and extraction was quantified by Kelemen and Aharonov (1998), who also proposed that

448 periodic pressure changes associated with fracturing might be responsible for some of the characteristic

449 modal layering observed throughout the lower crust and MTZ sills. Nevertheless, melt extraction could

450 also take place in conduits of focused porous flow, possibly represented by cross-cutting anorthosite veins

451 and (transposed?) anorthosite bands (Kelemen \& Aharonov 1998; Morales et al., 2011).

452 In contrast, Lissenberg et al. (2013) examined a suite of samples dredged from the $\sim 4.5 \mathrm{~km}$ thick

453 lower crustal section at Hess Deep on the East Pacific Rise and concluded that the major and trace

454 element characteristics of the cumulate minerals require pervasive dissolution-reprecipitation of the

455 minerals upsection in Hess Deep. Lissenberg et al. (2013) made several fundamental observations that are

456 important to list here in order to compare with our Khafifah data:

457 (1) Similar to the Khafifah gabbros, $\mathrm{Mg \#}$ in the cores of clinopyroxene from Hess Deep remains 458 within a narrow range (average of all analyses $\mathrm{Mg \#}=79 \pm 6$ at Hess Deep compared with $\mathrm{Mg \#}=$ 460 the lower $3 \mathrm{~km}$ of the crust.

461 (2) However, in contrast to the Khafifah gabbros, there is systematic variation in the An content of 462 plagioclase cores from Hess Deep from 77 at the base of the crust to 52 at the top (Fig. 13).

463 Plagioclase An contents in the first 1000 meters above the MTZ from Khafifah overlap with the 464 range measured in Hess Deep lower gabbros, though the Khafifah compositions fall within the 465 higher end of the Hess Deep range (Fig. 13). From $\sim 1000$ meters to the top of the gabbro section, 466 Khafifah plagioclase is systematically more An rich than at Hess Deep. Above a height of 2500

This article is protected by copyright. All rights reserved. 
m, plagioclase An from Hess Deep shows more variability, and is nearly 10 An units lower than in Khafifah at the same structural level (Fig. 13).

(3) in situ trace element concentrations in clinopyroxene and plagioclase in Hess Deep are generally not in equilibrium with one another at magmatic temperatures. Lissenberg et al. (2013) demonstrated that highly incompatible trace elements measured in plagioclase are depleted with respect to theoretical plagioclase in equilibrium with a MORB parental melt, whereas moderately incompatible trace elements are less depleted. We do not observe this relationship in the Khafifah section.

(4) In Hess Deep and Khafifah, there is an overall increase in incompatible trace element abundance in clinopyroxene and plagioclase from the base of crustal section to the top. Clinopyroxenes in Hess Deep samples have nearly constant $\mathrm{Zr}$ contents in the lower $2.5 \mathrm{~km}$ of gabbros, and increase 9-fold in the uppermost $1.8 \mathrm{~km}$. In Khafifah, clinopyroxene $\mathrm{Zr}$ contents increase systematically with decreasing depth (Fig. 8), but only double in concentration from the base to the top of the crust. Plagioclase Ce concentrations double from base to top in Khafifah (Fig. 8), but increase 7-

On the basis of their observations in Hess Deep samples, Lissenberg et al. (2013) argued for melt 484 transport dominated by reactive porous flow throughout an integrated permeable mush zone on the scale 485 of the entire lower crust. It is not clear how this scenario can explain the remaining, large variations in 486 clinopyroxene Mg\#, since Korenaga and Kelemen (1998) demonstrated that such variation would be 487 reduced or eliminated by large amounts of reactive porous flow of melt, which characteristically buffers 488 compatible element concentrstions and ratios to high, nearly constant values, while incompatible trace 489 element concentrations vary widely (Collier and Kelemen, 2010; Kelemen, 1986).

$490 \quad$ In any case, the upper gabbros at Hess Deep appear to be significantly more evolved, and/or have 491 experienced more modification by reactive porous flow of melt, and/or contain a larger proportion of melt 492 crystallized in a closed system than those measured in our study. In Khafifah, the lack of major element

This article is protected by copyright. All rights reserved. 
493 and compatible trace element compositional change in the lower gabbros, together with the preservation

494 of $\mathrm{cm}$ and m-scale cryptic variability in the lower gabbros (Browning, 1984; Browning et al., 1989;

495 Korenaga \& Kelemen 1997, 1998) demonstrate that large-scale porous melt flow was not the dominant

496 mechanism for melt extraction from the lower crust in the Samail ophiolite.

\subsection{Proportion of lower gabbro to upper gabbro in the oceanic lower crust}

499 In Wadi Khafifah in the southern Samail ophiolite, the lower gabbro comprises $71 \%$ of the total 500 gabbroic section $(3700 \mathrm{~m} / 5200 \mathrm{~m})$. In Wadi Gideah, just $15 \mathrm{~km}$ to the east of Wadi Khafifah, Mock et

501 al. (2021) documented a major change in plagioclase lattice preferred orientations at $3500 \mathrm{~m}$ depth in a

502 crustal section of $5010 \mathrm{~m}(\sim 69 \%)$. In Wadi Abyad, further to the north and west, in the Nakhl-Rustaq

503 block of the Samail ophiolite (Fig. 2), the gabbroic crustal section is $2600 \mathrm{~m}$ thick, containing $1800 \mathrm{~m}$ of

504 lower gabbro; approximately 69\% (Macleod and Yaouancq, 2000). In Hess Deep layered gabbro with

505 low incompatible trace element abundances comprise approximately $2550 \mathrm{~m}$ of the total $4350 \mathrm{~m}$ of

506 gabbroic crust (Lissenberg et al., 2013), a total of 59\% (though Gillis et al. (2014) subsequently estimated

507 that the layered gabbro comprises approximately $67.5 \%$ of the plutonic section). Thus, it appears that the

508 proportions of lower layered gabbro and upper gabbro are consistent, between c. $60-70 \%$, regardless of

509 the total lower crustal thickness.

510

5115.6 A Full Sheeted Sills model for lower crustal accretion

512 A long-standing debate exists over the on-axis magmatic architecture and style of lower crustal

513 accretion at mid-ocean ridges. Two end-member models and several hybrid models have been envisioned

514 to account for where magmas are primarily crystallized within the lower oceanic crust (Fig. 14). The

515 original Sheeted Sills model (Kelemen et al., 1997) postulates that the majority of the lower crust is

516 emplaced as a series of small melt lenses at a variety of depths, and crystallized near the crustal depth

517 where we now find them, in keeping with observations of ultramafic sills in the Bay of Islands ophiolite

518 (e.g., Bedard, 1991; Bedard \& Hebert, 1996, 1998; Bedard et al., 1988), the Rum intrusion (Emeleus and

This article is protected by copyright. All rights reserved. 
519 Troll, 2014; Hepworth et al., 2018), and the Kap Edvard Holm intrusion (Bernstein et al., 1996). In

520 contrast, the 'Gabbro Glacier' model (Sleep, 1975; Nicolas et al., 1989; Quick and Denlinger, 1993;

521 Phipps Morgan and Chen, 1993; Henstock et al., 1993) requires that all lower crustal gabbros are

522 crystallized in a shallow melt lens at the base of the sheeted dikes and flow downward and outward away

523 from the ridge axis to form the lower crust. Two additional 'hybrid' models intermediate to the Sheeted

524 Sills and Gabbro Glacier models have been proposed: Boudier et al. (1996) envisioned a crustal-scale

525 'Gabbro Glacier' into which small sills are periodically emplaced at a variety of depths. Maclennan et al.

526 (2004) modeled a hybrid section with a 1-1.5 km thick Gabbro Glacier just beneath the sheeted dikes, a

$527 \sim 1-1.5 \mathrm{~km}$ thick "mixed" section, and a $\sim 1-1.5 \mathrm{~km}$ thick Sheeted Sills section at the base of the crust. In

528 fact, the 'hybrid' model of Maclennan et al. (2004) is similar to the original Sheeted Sills model in Figure

5296 of Kelemen et al. (1997), which included a thin gabbro glacier layer between the sheeted dikes and the

530 layered gabbros. Mock et al. (2021) argued for a Hybrid-style model similar to Maclennan et al. (2004)

531 and Kelemen et al. (1997) on the basis of plagioclase LPO. No one has actually illustrated or advocated a

532 true, end-member Sheeted Sill model.

533 Our major and trace element data for the Khafifah lower crust in the Oman ophiolite, combined

534 with previous work on the cooling rate and magmatic fabrics in the same section, allows us to place new

535 constraints on melt dynamics and magmatic plumbing in the lower crust at the ridge axis. Our previous

536 studies documenting fast cooling rates throughout the lower crust (Garrido et al., 2001; VanTongeren et

537 al., 2008) and a lack of increasing strain with depth from plagioclase lattice preferred orientation

538 (VanTongeren et al., 2015) are not consistent with the Gabbro Glacier or either variety of the Hybrid

539 models for this section. Moreover, as noted above, the non-systematic but significant variation in mineral

540 compositions in the lower gabbros rules out pervasive, reactive melt transport of the upper crustal

541 magmas through the lower crustal gabbros. Because the large ductile strains required by the Gabbro

542 Glacier model necessitate melt porosities of 10 to $20 \%$ to facilitate melt-lubricated, pressure-solution

543 accomodated, grain boundary sliding (e.g., Nicolas and Ildefonse, 1996; Chenevez et al., 1998), and

544 because the lower gabbro compositions do not contain such large proportions of melt crystallized in a

This article is protected by copyright. All rights reserved. 
545 closed system (Fig. 9), the Gabbro Glacier models require large amounts of melt extraction via porous

546 flow. Thus, the Gabbro Glacier models are not consistent with observed variation in the minerals and

547 whole rock samples of the Khafifah lower gabbros. The similarity of mineral cores in the upper and

548 lower gabbros in the Khafifah section is also inconsistent with prior illustrations of the Sheeted Sills

549 model, in which a shallow melt lens and a small Gabbro Glacier is fed entirely by evolved melt from

550 deeper lenses (e.g. Kelemen et al., 1997b; Korenaga and Kelemen, 1998; Kelemen and Aharanov, 1998).

551 Instead, we propose a Full Sheeted Sills model, in which the entire lower crust forms via

552 crystallization from primary mafic magmas in lenses distributed at depths from the MTZ to the base of

553 the sheeted dikes. The observation of mineral cores with primitive compositions in the upper gabbros

554 suggests that primary melts from the mantle are not only restricted to the lower gabbros, but are also

555 periodically emplaced in the upper gabbros and AMC. Indeed, in erupted basalts from the East Pacific

556 Rise, Wanless and Shaw (2012) showed that between 60-100\% of crystal cargos were crystallized at

557 shallow crustal levels corresponding to the AMC, despite having very primitive major element basaltic

558 compositions.

559 In the Full Sheeted Sills model, there is no initial distinction between upper and lower gabbro on-

560 axis beneath an axial magma chamber (AMC) at the base of the sheeted dikes. After initial

561 crystallization, evolved melt is efficiently extracted from the lower 60-70\% of the gabbroic crust (the

562 lower gabbros). Some of this evolved melt, together with earlier formed cumulate minerals, crystallizes

563 to form the upper 30-40\% of the gabbroic crust (the upper gabbros), while the remainder mixes with

564 residual melt in the AMC and upper gabbros and erupts to form the overlying sheeted dikes and lavas.

565 Our Full Sheeted Sills model places tighter constraints on which crustal levels contribute magma

566 during melt extraction events. Our model implies that periodic fracturing induced by magma recharge into

567 the lower crust allows fractionated melt to quickly leave the lower crustal cumulates. While trapping

568 pressures calculated from melt inclusions erupted to the seafloor show that some lavas are derived

569 directly from the lower crust (Wanless and Shaw, 2012), the majority of evolved melts may stall and

570 crystallize in situ when they encounter the axial magma chamber (AMC), or another high porosity region

This article is protected by copyright. All rights reserved. 
571 below the AMC, as suggested by Kelemen and Aharonov (1998). The liquids calculated to be in

572 equilibrium with the lower gabbro mineral compositions (Fig. 11) overlap with the upper gabbro whole

573 rock compositions and the more primitive sheeted dike compositions in our section. It is therefore likely

574 that much of the expelled melt from the lower gabbros accumulated within the upper gabbros in the

575 Khafifah section prior to eruption to form the sheeted dikes and lavas.

576 Crystallization of hot primitive magmas at all levels within the lower crust requires the removal

577 of a signficiant amount of latent heat. Using the same set of samples as this study, VanTongeren et al.

578 (2008) showed that the lower crust in Wadi Khafifah experienced very rapid and uniform cooling rates,

579 likely due to penetration of hydrothermal fluids from the seafloor all the way to the MTZ. Hydrothermal

580 circulation of seawater through the oceanic crust is a highly efficient way to remove the latent heat of

581 crystallization thoughout the lower crust at mid-ocean ridges and allow for on-axis crystallization at all

582 crustal levels (e.g. Cherkaoui et al., 2000; Hasenclever et al., 2014).

\section{3}

\section{$584 \quad 5.7$ Influence of structure and emplacement on compositional variability}

585 As mentioned above, the geochemical transition between upper and lower gabbro lies

586 stratigraphically below the outcrop-scale distinction between 'layered gabbro' and 'transitional gabbro' of

587 Pallister and Hopson (1981). The geochemical transition, however, is roughly coincident with a change

588 in plagioclase fabrics at the grain-scale. Working with the same set of samples, VanTongeren et al.

589 (2015) showed that there is a clear transition in plagioclase lattice preferred orientations (LPO) at $\sim 3500$

$590 \mathrm{~m}$ in the $\mathrm{W}$. Khafifah section, i.e. approximately $700 \mathrm{~m}$ below the layered gabbro - transitional gabbro

591 contact based on outcrop foliations (e.g. Pallister and Hopson, 1981).

592 Below $3500 \mathrm{~m}$, the lower layered gabbros have plagioclase LPOs defined by (010) axes aligned

593 perpendicular to the MTZ, so that the long axes of plagioclase crystals are parallel to the paleo-seafloor

594 (VanTongeren et al., 2015). In contrast, the gabbros above $3500 \mathrm{~m}$ have plagioclase (010) aligned

595 parallel to the MTZ, resulting in near-vertical foliation with respect to the paleo-seafloor. A single

This article is protected by copyright. All rights reserved. 
596 transitional sample, OM97-106 from $3260 \mathrm{~m}$, records a sub-vertical fabric with respect to the seafloor;

597 interestingly this sample also has more evolved mineral compositions.

598 The fact that the transition in the outcrop-scale textures is stratigraphically distinct from the

599 coincident geochemical and plagioclase fabric transition is critical to understanding melt dynamics in the

600 upper gabbros. We propose that the upper gabbros initially form in the same way as the lower gabbros,

601 by crystallization in small sills of primitive melt, and that the change in outcrop-scale layering and

602 plagioclase-defined foliation direction is a result of either (1) melt migration upwards during diking

603 events (e.g. Macleod and Rothery, 1992; Macleod and Yauoancq, 2000; VanTongeren et al., 2015; Mock

604 et al., 2021) or (2) compaction and shearing (e.g. Nicolas et al., 2009) in the presence of larger interstitial

605 melt fractions in the upper gabbros as compared with the lower gabbros. This is distinct from a 'Gabbro

606 Glacier' model sensu strictu, in that the upper gabbros in our model do not crystallize solely from a single

607 thin axial melt lens and then flow downward and outward to form a thicker gabbroic layer. Instead, we

608 infer that they are emplaced and crystallized in situ but are more susceptible to large-scale rotations

609 because they contain larger melt fractions during on-axis deformation. Geochemical data from this study

610 support the idea that the plagioclase fabric and outcrop-scale foliation are influenced by the proportion of

611 interstitial melt on-axis (Fig. 15), as the stratigraphic change in plagioclase fabric coincides almost

612 exactly with the geochemical transition to more evolved gabbros in the crust.

613

614 5.9 An estimated major element bulk composition for the crust

615 An estimated major and trace element bulk lower crust composition was calculated by weighting

616 each whole rock analysis according to its position within the stratigraphy (Table 2), a method similar to

617 that applied by VanTongeren et al. (2010) for the Upper Zone of the Bushveld Complex layered intrusion.

618 A previous estimate for the bulk composition of the lower crust in the Wadi Tayin massif was made by

619 simple averaging of $<20$ "representative" whole rock compositions for each unit (<5 for the "high-level"

620 gabbros) in the gabbroic stratigraphy (Pallister and Gregory, 1983; composition shown in Table 9). The

621 method employed here for obtaining the bulk composition is an improvement over that of Pallister and

This article is protected by copyright. All rights reserved. 
622 Gregory (1983) because it accounts for stratigraphic variation in the gabbro column due to crystal

623 fractionation and evolving geochemistry.

$624 \quad$ The Lower Gabbros

625 Our estimated bulk composition for the lower gabbros is listed in Table 9. Root mean square

626 errors on the estimate are determined by omitting a quarter of the samples (7 of 28) and repeatedly

627 recalculating the bulk composition a total of four times (see Suppl. Table 2 for details). This jack-knife

628 statistical resampling technique shows that our bulk composition estimate for the lower gabbros is highly

629 robust and is unlikely to change with additional sampling.

630 Only gabbros with typical modal proportions ( 50-60 plag: $35-40 \mathrm{cpx}$ : 5-10 ol) were included in

631 our compilation. While wehrlite and anorthosite layers are present in the Khafifah section, we do not

632 include any analyses of these lithologies in our bulk composition. Wehrlites (also referred to as

633 'melanogabbro'), composed of olivine, clinopyroxene and minor plagioclase, intrude and are interlayered

634 with gabbros throughout the Samail ophiolite (e.g., Koga et al., 2001; Benn et al., 1988). In general, these

635 seem to have formed by crystallization of magmas with the same major and trace element composition as

636 the gabbros, with the addition of enough water - perhaps seawater - to shift the crystallization sequence

637 from ol-plag-cpx to ol-cpx-plag (Benoit et al., 1996; Koepke et al, 2009; Koepke et al., 2014; Feig et al.,

638 2006). In the Khafifah section, wehrlites comprise less than $10 \%$, probably less than 5\%, and do not

639 significantly affect the results presented here. That said, few if any wehrlites have been recovered from

640 the mid-ocean ridges, so their presence in the Samail ophiolite may indicate some differences in the

641 mechanism of crustal formation for the ophiolite compared to mid-ocean ridge crust. In the case of

642 anorthosites, plagioclase-only layers are small $(<\mathrm{m}$-scale) in the crustal section. They may form by

643 typical magma chamber dynamics and crystal sorting, and/or as a result of decompression due to

644 magmatic fracturing (Kelemen \& Aharonov 1998, their Figure 9 and related text; Morales et al. 2011;

645 Boudier and Nicolas, 2011).

646 The newly calculated bulk composition for the Khafifah lower gabbros is more primitive than that

647 previously estimated for lower gabbros in the Samail ophiolite by Pallister and Gregory (1983) (Table 9).

This article is protected by copyright. All rights reserved. 
648 Their lower gabbro composition has signifiantly higher $\mathrm{SiO}_{2}$ (49.9 vs. $48 \%$ in this study) and higher $\mathrm{FeO}$

649 (6\% vs. 5.5\%); whereas, our estimate for Khafifah has significantly more $\mathrm{Al}_{2} \mathrm{O}_{3}, \mathrm{MgO}$, and $\mathrm{CaO}$ (Table

650 9). Pallister and Gregory (1983) included the transitional gabbro section (4200 -4700 m) in their

651 compilation of lower gabbros, which is likely the cause of their more evolved composition relative to this 652 study.

653 The nearby Wadi Gideah $(\sim 10 \mathrm{~km}$ to the east; Fig. 2$)$ is the site of the recent ICDP Oman Drilling

654 Project, which intersected the lower gabbros in core GT1. An average of 56 gabbro compositions

655 measured over $400 \mathrm{~m}$ (Chikyu curated depth) of core (Kelemen et al., 2020a) yields a bulk composition

656 remarkably similar to our calculated Khafifah lower gabbro section (Table 9).

\section{The Upper Gabbros}

659 Due to a paucity of fresh outcrop for sampling in the upper gabbro section, our dataset includes

660 only four exceptionally fresh samples from $3700 \mathrm{~m}-4700 \mathrm{~m}$, three of which correspond to the

661 'transitional gabbros' in the stratigraphic column of Pallister and Hopson (1981). We do not have any

662 samples representing the $500 \mathrm{~m}$ thick 'high-level' gabbro section of Pallister and Hopson (1981), from

$6634700-5200 \mathrm{~m}$. We therefore incorporate the 'high-level' gabbro composition from Pallister and Gregory

664 (1983) for this section, including their estimate of $0.1 \%$ plagiogranite $(\sim 5.2 \mathrm{~m})$, into our upper gabbro

665 bulk composition. The resulting upper gabbro bulk composition (Table 9) is distinct from that reported

666 by Pallister and Gregory (1983) in that it includes the interval from 3700-4700 m, which was previously

667 incorporated into their lower gabbro estimate.

668 Employing the same jack-knife statistical resampling strategy as was use in the lower gabbros

669 above, we calculate RMSE uncertainties for the upper gabbro bulk composition shown in Table 9 (see full

670 calculation in Suppl. Table 2 for details). While the uncertainties are higher than those reported for the

671 lower gabbros, they are still very small $(<0.5 \mathrm{wt} \%$ for most elements), giving us good confidence in the

672 compositions estimated here.

This article is protected by copyright. All rights reserved. 
674 through the upper gabbros in Wadi Gideah. Core GT2 drilled through 'foliated' gabbros into 'layered'

675 gabbros, intersecting approximately $50 \mathrm{~m}$ of evolved, but olivine-bearing, gabbro at the top (Kelemen et

676 al., 2020b). Core GT3 drilled through the sheeted dike to gabbro transition, intersecting evolved, olivine-

677 free gabbro, diorite, and diabase in the lowermost $180 \mathrm{~m}$ (Kelemen et al., 2020c). The compositions of

678 samples from the Khafifah upper gabbros measured here overlap with those in cores from GT2 and GT3

679 (Fig. 16). A very rough estimate of the bulk upper gabbro section of Wadi Gideah can be made by

680 assuming a stratigraphic equivalent of $1000 \mathrm{~m}$ for the GT2 'foliated gabbros' of Wadi Gideah, and a 500

$681 \mathrm{~m}$ stratigraphic equivalent for the GT3 gabbros and diorites (similar to the 'high-level' gabbro distinction

682 of Pallister and Hopson, 1981). While it is not our intent to provide a detailed comparison of Wadi

683 Gideah and Khafifah, this rough estimate of the upper gabbro section of Wadi Gideah is similar in most

684 respects to our Khafifah estimate (Table 9), providing additional confidence in the results and

685 interpretations presented here.

686 The complete bulk lower crust composition for the Khafifah section is calculated by

687 stratigraphically weighted summation of the compositions of lower gabbro (3700 m) and the upper gabbro

688 (1500 m). The bulk Khafifah gabbroic lower crust has very similar composition to that estimated for

689 Hess Deep lower crust from Gillis et al. (2014)(Table 9), except that the Khafifah gabbro section has

690 higher $\mathrm{CaO}$ and lower $\mathrm{MgO}$. This difference could be caused by a higher An content of plagioclase in the

691 Khafifah section as compared to Hess Deep (Figs. 3, 13), and/or the slightly less evolved upper gabbros

692 in Khafifah (Mg\# 63.7) compared to those reported by Gillis et al. (2014) and Lissenberg et al. (2013) for

693 Hess Deep $(\mathrm{Mg} \#=62)$.

694 The bulk crustal composition of W. Khafifah (Table 9) includes the entire $5.2 \mathrm{~km}$ plutonic

695 section, plus an additional $2 \mathrm{~km}$ (previously estimated for this section by Pallister and Gregory, 1983) of

696 extrusive material represented by the average of the sheeted dike compositions reported in Table 2b. This

697 new estimate of bulk crustal composition contains $49.91 \mathrm{wt} \% \mathrm{SiO}_{2}, 8.97 \mathrm{wt} \% \mathrm{MgO}$, and has an $\mathrm{Mg} \#$ of

698 68.7. Assuming that the primitive mantle melt that formed the Khafifah crust had molar $\mathrm{Fe}^{3+} / \mathrm{Fe}_{\text {total }}$ of 14-

This article is protected by copyright. All rights reserved. 
$69916 \%$ (Cottrell and Kelley, 2011), this yields a composition with molar $\mathrm{Mg} /\left(\mathrm{Mg}+\mathrm{Fe}^{2+}\right)$ of $72.9-73.5$, in

700 equilibrium with Fo89-90 olivine typical of residual mantle harzburgites in ophiolites and mid-ocean

701 ridge peridotites.

702 The bulk rock gabbro major element compositions from the Khafifah section appear to define a

703 continuum in $\mathrm{SiO}_{2}-\mathrm{MgO}$ with the sheeted dikes and lavas in the southern massifs of the Samail ophiolite

704 (Fig. 16). This continuum stretches from the depleted MORB mantle (from Workman and Hart, 2005)

705 and encompasses the compositions of average MORB from Gale et al. (2013). The Khafifah bulk

706 composition is similar to primitive MORB melts that have undergone little to no olivine fractionation

707 after mantle melting. We infer that mantle-derived melts are directly transported from the melting region

708 to the lower crust. In this view, most of the olivine in dunite in the Mantle Transition Zone is original

709 mantle olivine, modified by reaction with primitive melt.

710

\section{Conclusions}

712

713 We present major and trace element compositions for whole rock and minerals from the lower crust of the

714 Wadi Khafifah section of the Wadi Tayin massif of the Samail ophiolite. We also present geochemical

715 data on sheeted dikes in the Samail and Wadi Tayin massifs, the two southern massifs of the Samail

716 ophiolite. These two massifs have whole rock and mineral compositions that are more similar to samples

717 from fast-spreading mid-ocean ridges than in any other ophiolite worldwide. Though the rock and mineral

718 compositions are slightly but systematically different from mid-ocean ridge samples, our data shed light

719 on the general processes of crustal genesis at oceanic spreading ridges.

720

721 Our data show a geochemical distinction between lower gabbros (0-3700 m above MTZ) and upper

722 gabbros $(3700-5200 \mathrm{~m})$, which is approximately coincident with a change in plagioclase

723 crystallographic orientations. Major element mineral compositions in the lower gabbros do not change

This article is protected by copyright. All rights reserved. 
724 systematically with depth, and trace element enriched crystal rims and interstitial material forms less than

$72510 \%$ of the lower gabbros. In contrast, upper gabbros become markedly more evolved in both major and

726 trace element concentrations and contain a significant fraction of enriched crystal rims and interstitial

727 material, some of which may be melt that crystallized entirely in a closed system. We propose a new Full

728 Sheeted Sills model for magmatic accretion of oceanic crust, in which the majority of melt is extracted

729 from lower gabbros in magmatic fractures or conduits of focused porous flow, and transported into the

730 upper gabbros prior to further crystallization and eventual transport via dikes to sites of eruption on the

731 seafloor.

733 We reconstruct bulk compositional estimates for the lower gabbros, the upper gabbros, the sheeted dikes,

734 and the entire Khafifah crustal section. Our estimated composition agrees well with estimates from other

735 exposed sections in the Samail ophiolite, and from the tectonically exposed oceanic crust at Hess Deep on

736 the fast-spreading EPR. These compositions form a continuum between the mantle source region (DMM)

737 and the sheeted dikes and lavas, thus defining a likely liquid line of descent for aggregated MORB-like

738 melts. Combining gabbro, sheeted dike, and lava compositions yields a bulk composition for the

739 Khafifah crust that corresponds to a plausible mantle-derived primary MORB composition in equilibrium

740 with depleted MORB mantle and parental to fast-speading oceanic crust.

\section{Acknowledgments, Samples, and Data}

742 The authors have no conflicts of interest. The authors thank all of the many individuals who have

743 contributed data, thoughts, or stimulating intellectual discussions over the 20+ years of work represented

744 here on the Wadi Khafifah crustal section and the southern Samail ophiolite.

Full datasets for this research are available from:

Prior to publication, datasets are available from:

https://datadryad.org/stash/share/OIFsyNfyLLlrK4gA4NsiITQFwaIPE3b9TvfrAcHQyuM.

After publication, the following DOI will be active:

750 VanTongeren, Jill et al. (2021), The composition of the lower oceanic crust in the Wadi Khafifah section

751 of the southern Samail (Oman) ophiolite, Dryad, Dataset, https://doi.org/10.5061/dryad.c59zw3r6v 


\section{References}

754 Alabaster, T., Pearce, J.A. and Malpas, J., 1982. The volcanic stratigraphy and petrogenesis of 755 the Oman ophiolite complex. Contributions to Mineralogy and Petrology 81, 168-183.

757 Alt, J. C., Teagle, D. A. H., Umino, S., Miyashita, S., Banerjee, N. R., Wilson, D. S., and the 758 IODP Expeditions 309 and 312 Scientists, and the ODP Leg 206 Scientific Party: IODP 759 Expeditions 309 and 312 Drill an Intact Section of Upper Oceanic Basement into Gabbros, Sci. 760 Dril., 4, 4-10, https://doi.org/10.2204/iodp.sd.4.01.2007, 2007.

761 Anonymous, 1972, Penrose Field Conference on ophiolites: Geotimes, v. 17, p. 24-25.

762 Barnes, S.J., 1986. The effect of trapped liquid crystallization on cumulus mineral compositions

763 in layered intrusions. Contributions to Mineralogy and Petrology, 93(4), pp.524-531.

764 Bédard, J.H. and Hébert, R., 1996. The lower crust of the Bay of Islands ophiolite, Canada: 765 petrology, mineralogy, and the importance of syntexis in magmatic differentiation in ophiolites 766 and at ocean ridges. Journal of Geophysical Research: Solid Earth, 101(B11), pp.25105-25124.

767 Bédard, J.H. and Hébert, R., 1998. Formation of chromitites by assimilation of crustal 768 pyroxenites and gabbros into peridotitic intrusions: North Arm Mountain massif, Bay of Islands 769 ophiolite, Newfoundland, Canada. Journal of Geophysical Research: Solid Earth, 103(B3), 770 pp.5165-5184.

771 Bédard, J.H., 1991. Cumulate recycling and crustal evolution in the Bay of Islands ophiolite. The 772 Journal of Geology, 99(2), pp.225-249.

773 Bedard, J.H., Hebert, R., Berclaz, A. and Varfalvy, V., 2000. Syntexis and the genesis of lower 774 oceanic crust. SPECIAL PAPERS-GEOLOGICAL SOCIETY OF AMERICA, pp.105-120.

775 Benn, K., Nicolas, A. and Reuber, I., 1988. Mantle — crust transition zone and origin of wehrlitic 776 magmas: Evidence from the Oman ophiolite. Tectonophysics, 151(1-4), pp.75-85.

777 Benoit, M., Polvé, M. and Ceuleneer, G., 1996. Trace element and isotopic characterization of 778 mafic cumulates in a fossil mantle diapir (Oman ophiolite). Chemical Geology, 134(1-3), pp.199779214.

780 Bernstein, S., Kelemen, P.B. and Brooks, C.K., 1996. Evolution of the Kap Edvard Holm 781 Complex: a mafic intrusion at a rifted continental margin. Journal of Petrology, 37(3), pp.497782519.

783 Bodinier, J.L. and Godard, M., 2003. Orogenic, ophiolitic, and abyssal peridotites. Treatise on 784 geochemistry, 2, p.568. 
786 Borghini, G. and Rampone, E., 2007. Postcumulus processes in oceanic-type olivine-rich 787 cumulates: the role of trapped melt crystallization versus melt/rock interaction. Contributions to 788 Mineralogy and Petrology, 154(6), pp.619-633.

789 Boudier, F. and Nicolas, A., 2011. Axial melt lenses at oceanic ridges-A case study in the 790 Oman ophiolite. Earth and Planetary Science Letters, 304(3-4), pp.313-325.

791 Boudier, F., Nicolas, A. and Ildefonse, B., 1996. Magma chambers in the Oman ophiolite: fed 792 from the top and the bottom. Earth and Planetary Science Letters, 144(1-2), pp.239-250.

793 Bown, J.W. and White, R.S., 1994. Variation with spreading rate of oceanic crustal thickness and 794 geochemistry. Earth and Planetary Science Letters, 121(3-4), pp.435-449.

795 Brown, T.C., Cheadle, M.J., John, B.E., Coogan, L.A., Gee, J.S., Karson, J.A. and Swapp, S.M., 796 2019. Textural Character of Gabbroic Rocks from Pito Deep: a Record of Magmatic Processes 797 and the Genesis of the Upper Plutonic Crust at Fast-Spreading Mid-Ocean Ridges. Journal of 798 Petrology, 60(5), pp.997-1026.

799 Browning, P., S. Roberts, and T. Alabaster, Fine-scale modal layering and cyclic units in 800 ultramafic cumulates from the CY-4 Borehole, Troodos Ophiolite; evidence for an open system 801 magma chamber, Cyprus Crustal Study Project, hole CY-4 initial report, pp. 193-220. Geol.

802 Surv. of Can., Ottawa, 1989.

803 Cann, J.R., 1974. A model for oceanic crystal structure developed. Geophysical Journal 804 International, 39(1), pp.169-187.

805 Cannat, M., 1996. How thick is the magmatic crust at slow spreading oceanic ridges?. Journal of 806 Geophysical Research: Solid Earth, 101(B2), pp.2847-2857.

807 Chen, Y.J., 1992. Oceanic crustal thickness versus spreading rate. Geophysical Research Letters, 808 19(8), pp.753-756.

809 Chenevez, J., Machetel, P. and Nicolas, A., 1998. Numerical models of magma chambers in the 810 Oman ophiolite. Journal of Geophysical Research: Solid Earth, 103(B7), pp.15443-15455.

811 Cherkaoui, A.S., Wilcock, W.S., Dunn, R.A. and Toomey, D.R., 2003. A numerical model of 812 hydrothermal cooling and crustal accretion at a fast spreading mid-ocean ridge. Geochemistry, 813 Geophysics, Geosystems, 4(9).

814 Christensen, N.I. and Smewing, J.D., 1981. Geology and seismic structure of the northern 815 section of the Oman ophiolite. Journal of Geophysical Research: Solid Earth, 86(B4), pp.25458162555.

817

818 Coleman, R.G., 2012. Ophiolites: ancient oceanic lithosphere? (Vol. 12). Springer Science \& 819 Business Media.

820 Collier, M.L. and Kelemen, P.B., 2010. The case for reactive crystallization at mid-ocean ridges. 821 Journal of Petrology, 51(9), pp.1913-1940. 
823 Coulthard, D. A., Reagan, M. K., Shimizu, K., Bindeman, I. N., Brounce, M., Almeev, R. R., et 824 al. (2021). Magma source evolution following subduction initiation: Evidence from the element 825 concentrations, stable isotope ratios, and water contents of volcanic glasses from the Bonin 826 forearc (IODP expedition 352). Geochemistry, Geophysics, Geosystems 22, e2020GC009054.

827 Dewey, J.F. and Kidd, W.S.F., 1977. Geometry of plate accretion. Geological Society of America 828 Bulletin, 88(7), pp.960-968.

829 Dick, H.J. and Bullen, T., 1984. Chromian spinel as a petrogenetic indicator in abyssal and 830 alpine-type peridotites and spatially associated lavas. Contributions to mineralogy and petrology, $831 \quad 86(1)$, pp.54-76.

832 Dick, H.J., Lin, J. and Schouten, H., 2003. An ultraslow-spreading class of ocean ridge. Nature, 833 426(6965), pp.405-412.

834 Dick, H.J., Natland, J.H. and Ildefonse, B., 2006. Past and future impact of deep drilling in the oceanic crust and mantle. Oceanography, 19(4), pp.72-80.

836 Emeleus, C.H. and Troll, V.R., 2014. The Rum Igneous Centre, Scotland. Mineralogical 837 Magazine, 78(4), pp.805-839.

838 Feig, S.T., Koepke, J. and Snow, J.E., 2006. Effect of water on tholeiitic basalt phase equilibria: 839 an experimental study under oxidizing conditions. Contributions to Mineralogy and Petrology, $840 \quad 152(5)$, pp.611-638.

841 Ferrini, V.L., Shillington, D.J., Gillis, K., MacLeod, C.J., Teagle, D.A., Morris, A., Cazenave, 842 P.W., Hurst, S. and Tominaga, M., 2013. Evidence of mass failure in the Hess Deep Rift from 843 multi-resolutional bathymetry data. Marine Geology, 339, pp.13-21.

844 Forsyth, D.W., 1993. Crustal thickness and the average depth and degree of melting in fractional 845 melting models of passive flow beneath mid-ocean ridges. Journal of Geophysical Research: 846 Solid Earth, 98(B9), pp.16073-16079.

847 France, L., Ildefonse, B. and Koepke, J., 2009. Interactions between magma and hydrothermal 848 system in Oman ophiolite and in IODP Hole 1256D: Fossilization of a dynamic melt lens at fast 849 spreading ridges. Geochemistry, Geophysics, Geosystems, 10(10).

850 France, L., Ildefonse, B. and Koepke, J., 2013. Hydrous magmatism triggered by assimilation of 851 hydrothermally altered rocks in fossil oceanic crust (northern Oman ophiolite). Geochemistry, 852 Geophysics, Geosystems, 14(8), pp.2598-2614.

853 France, L., Koepke, J., MacLeod, C.J., Ildefonse, B., Godard, M. and Deloule, E., 2014. 854 Contamination of MORB by anatexis of magma chamber roof rocks: Constraints from a 855 geochemical study of experimental melts and associated residues. Lithos, 202, pp.120-137.

856 Gale, A., Dalton, C.A., Langmuir, C.H., Su, Y. and Schilling, J.G., 2013. The mean composition 857 of ocean ridge basalts. Geochemistry, Geophysics, Geosystems, 14(3), pp.489-518. 
858 Garrido, C.J., Kelemen, P.B. and Hirth, G., 2001. Variation of cooling rate with depth in lower 859 crust formed at an oceanic spreading ridge: Plagioclase crystal size distributions in gabbros from 860 the Oman ophiolite. Geochemistry, Geophysics, Geosystems, 2(10). Gillis, K.M., Snow, J.E., Klaus, A., Abe, N., Adriao, A.B., Akizawa, N., Ceuleneer, G., Cheadle, M.J., Faak, K., Falloon, T.J. and Friedman, S.A., 2014. Primitive layered gabbros from fast-

863 spreading lower oceanic crust. Nature, 505(7482), pp.204-207.

864 Gillis, K.M., Snow, J.E., Klaus, A., Guerin, G., Abe, N., Akizawa, N., Ceuleneer, G., Cheadle, 865 M.J., Adrião, Á., Faak, K. and Falloon, T.J., 2012. Geochemistry summary. In Proc. IODP 866 Volume (Vol. 345, p. 2).

867 Godard, M., Awaji, S., Hansen, H., Hellebrand, E., Brunelli, D., Johnson, K., Yamasaki, T., 868 Maeda, J., Abratis, M., Christie, D. and Kato, Y., 2009. Geochemistry of a long in-situ section of 869 intrusive slow-spread oceanic lithosphere: Results from IODP Site U1309 (Atlantis Massif, $30 \mathrm{~N}$ 870 Mid-Atlantic-Ridge). Earth and Planetary Science Letters, 279(1-2), pp.110-122.

871 Godard, M., Bosch, D. and Einaudi, F., 2006. A MORB source for low-Ti magmatism in the 872 Semail ophiolite. Chemical Geology, 234(1-2), pp.58-78.

873 Godard, M., Dautria, J.M. and Perrin, M., 2003. Geochemical variability of the Oman ophiolite 874 lavas: Relationship with spatial distribution and paleomagnetic directions. Geochemistry,

875 Geophysics, Geosystems, 4(6).

876 Godard, M., Jousselin, D. and Bodinier, J.L., 2000. Relationships between geochemistry and 877 structure beneath a palaeo-spreading centre: a study of the mantle section in the Oman ophiolite. 878 Earth and Planetary Science Letters, 180(1-2), pp.133-148.

879 Hanghøj, K., Kelemen, P.B., Hassler, D. and Godard, M., 2010. Composition and genesis of 880 depleted mantle peridotites from the Wadi Tayin Massif, Oman Ophiolite; major and trace 881 element geochemistry, and Os isotope and PGE systematics. Journal of Petrology, 51(1-2), 882 pp.201-227.

883 Hasenclever, J., Theissen-Krah, S., Rüpke, L.H., Morgan, J.P., Iyer, K., Petersen, S. and Devey, 884 C.W., 2014. Hybrid shallow on-axis and deep off-axis hydrothermal circulation at fast-spreading 885 ridges. Nature, 508(7497), pp.508-512.

886 Hart, S.R., Blusztajn, J., Dick, H.J., Meyer, P.S. and Muehlenbachs, K., 1999. The fingerprint of 887 seawater circulation in a 500-meter section of ocean crust gabbros. Geochimica et Cosmochimica 888 Acta, 63(23-24), pp.4059-4080.

889 Henstock, T.J., Woods, A.W. and White, R.S., 1993. The accretion of oceanic crust by episodic 890 sill intrusion. Journal of Geophysical Research: Solid Earth, 98(B3), pp.4143-4161.

891

892

893

894
Hepworth, L.N., O’Driscoll, B., Gertisser, R., Daly, J.S. and Emeleus, C.H., 2018. Linking in situ crystallization and magma replenishment via sill intrusion in the Rum Western Layered Intrusion, NW Scotland. Journal of Petrology, 59(8), pp.1605-1642. 
Ishikawa, T., Nagaishi, K. and Umino, S., 2002, Boninitic volcanism in the Oman ophiolite: Implications for thermal condition during transition from spreading ridge to arc: Geology 30, 899-902.

Johnson, K.T., Dick, H.J. and Shimizu, N., 1990. Melting in the oceanic upper mantle: an ion microprobe study of diopsides in abyssal peridotites. Journal of Geophysical Research: Solid Earth, 95(B3), pp.2661-2678.

901 Karson, J.A., Klein, E.M., Hurst, S.D., Lee, C.E., Rivizzigno, P.A., Curewitz, D., Morris, A.R., 902 Miller, D.J., Varga, R.G., Christeson, G.L. and Cushman, B., 2002. Structure of uppermost fast903 spread oceanic crust exposed at the Hess Deep Rift: Implications for subaxial processes at the 904 East Pacific Rise. Geochemistry, Geophysics, Geosystems, 3(1).

905 Kelemen, P.B., 1986. Assimilation of ultramafic rock in subduction-related magmatic arcs. The 906 Journal of Geology, 94(6), pp.829-843.

907 Kelemen, P.B. and Aharanov, E., 1998. Periodic formation of magma fractures and generation of 908 layered gabbros in the lower crust beneath oceanic spreading ridges. GEOPHYSICAL

909 MONOGRAPH-AMERICAN GEOPHYSICAL UNION, 106, pp.267-290.

910 Kelemen, P.B., Hirth, G., Shimizu, N., Spiegelman, M. and Dick, H.J., 1997a. A review of melt 911 migration processes in the adiabatically upwelling mantle beneath oceanic spreading ridges.

912 Philosophical Transactions of the Royal Society of London. Series A: Mathematical, Physical 913 and Engineering Sciences, 355(1723), pp.283-318.

914 Kelemen, P.B., Koga, K. and Shimizu, N., 1997b. Geochemistry of gabbro sills in the crust915 mantle transition zone of the Oman ophiolite: Implications for the origin of the oceanic lower 916 crust. Earth and Planetary Science Letters, 146(3-4), pp.475-488.

917 Kelemen, P.B., Matter, J.M., Teagle, D.A.H., Coggon, J.A., and the Oman Drilling Project 918 Team, 2020a. Site GT1: layered cumulate gabbros and deep fault zones. In: Kelemen, P.B., 919 Matter, J.M., Teagle, D.A.H., Coggon, J.A., and the Oman Drilling Project Team, Proceedings 920 of the Oman Drilling Project: College Station, TX (International Ocean Discovery Program). 921 https://doi.org/10.14379/OmanDP.proc.2020

922 Kelemen, P.B., Matter, J.M., Teagle, D.A.H., Coggon, J.A., and the Oman Drilling Project 923 Team, 2020b. Site GT2: foliated to layered gabbro transition. In: Kelemen, P.B., Matter, J.M., 924 Teagle, D.A.H., Coggon, J.A., and the Oman Drilling Project Team, Proceedings of the Oman 925 Drilling Project: College Station, TX (International Ocean Discovery Program).

926 https://doi.org/10.14379/OmanDP.proc.2020

927 Kelemen, P.B., Matter, J.M., Teagle, D.A.H., Coggon, J.A., and the Oman Drilling Project 928 Team, 2020c. Site GT3: sheeted dike to gabbro transition. In: Kelemen, P.B., Matter, J.M., 929 Teagle, D.A.H., Coggon, J.A., and the Oman Drilling Project Team, Proceedings of the Oman 930 Drilling Project: College Station, TX (International Ocean Discovery Program).

931 https://doi.org/10.14379/OmanDP.proc.2020 
932 Koepke, J., Berndt, J., Horn, I., Fahle, J. and Wolff, P.E., 2014. Partial melting of oceanic gabbro 933 triggered by migrating water-rich fluids: a prime example from the Oman Ophiolite. Geological

934 Society, London, Special Publications, 392(1), pp.195-212.

935 Koepke, J., France, L., Müller, T., Faure, F., Goetze, N., Dziony, W. and Ildefonse, B., 2011.

936 Gabbros from IODP Site 1256, equatorial Pacific: Insight into axial magma chamber processes at

937 fast spreading ocean ridges. Geochemistry, Geophysics, Geosystems, 12(9).

938 Koepke, J., Schoenborn, S., Oelze, M., Wittmann, H., Feig, S.T., Hellebrand, E., Boudier, F. and 939 Schoenberg, R., 2009. Petrogenesis of crustal wehrlites in the Oman ophiolite: Experiments and

940 natural rocks. Geochemistry, Geophysics, Geosystems, 10(10).

941 Koga, K.T., Kelemen, P.B. and Shimizu, N., 2001. Petrogenesis of the crust-mantle transition

942 zone and the origin of lower crustal wehrlite in the Oman ophiolite. Geochemistry, Geophysics,

943 Geosystems, 2(9).

944 Korenaga, J. and Kelemen, P.B., 1997. Origin of gabbro sills in the Moho transition zone of the 945 Oman ophiolite: Implications for magma transport in the oceanic lower crust. Journal of

946 Geophysical Research: Solid Earth, 102(B12), pp.27729-27749.

947 Korenaga, J. and Kelemen, P.B., 1998. Melt migration through the oceanic lower crust: a 948 constraint from melt percolation modeling with finite solid diffusion. Earth and Planetary 949 Science Letters, 156(1-2), pp.1-11.

950 Lissenberg, C.J. and Dick, H.J., 2008. Melt-rock reaction in the lower oceanic crust and its 951 implications for the genesis of mid-ocean ridge basalt. Earth and Planetary Science Letters, 952 271(1-4), pp.311-325.

953 Lissenberg, C.J. and MacLeod, C.J., 2016. A reactive porous flow control on mid-ocean ridge 954 magmatic evolution. Journal of Petrology, 57(11-12), pp.2195-2220.

955 Lissenberg, C.J., MacLeod, C.J., Howard, K.A. and Godard, M., 2013. Pervasive reactive melt 956 migration through fast-spreading lower oceanic crust (Hess Deep, equatorial Pacific Ocean). 957 Earth and Planetary Science Letters, 361, pp.436-447.

958 Maclennan, J., Hulme, T. and Singh, S.C., 2004. Thermal models of oceanic crustal accretion: 959 Linking geophysical, geological and petrological observations. Geochemistry, Geophysics, 960 Geosystems, 5(2).

961 MacLeod, C.J. and Rothery, D.A., 1992. Ridge axial segmentation in the Oman ophiolite: 962 evidence from along-strike variations in the sheeted dyke complex. Geological Society, London, 963 Special Publications, 60(1), pp.39-63.

964 MacLeod, C.J. and Yaouancq, G., 2000. A fossil melt lens in the Oman ophiolite: Implications 965 for magma chamber processes at fast spreading ridges. Earth and Planetary Science Letters, $966 \quad 176(3-4)$, pp.357-373. 
967 MacLeod, C.J. and Yaouancq, G., 2000. A fossil melt lens in the Oman ophiolite: Implications 968 for magma chamber processes at fast spreading ridges. Earth and Planetary Science Letters, 969 176(3-4), pp.357-373.

970 MacLeod, C.J., Johan Lissenberg, C. and Bibby, L.E., 2013. "Moist MORB” axial magmatism in 971 the Oman ophiolite: The evidence against a mid-ocean ridge origin. Geology, 41(4), pp.459-462.

972 MacLeod, C.J., Thomas, R.M. and Coogan, L.A., 2007. Fast-spreading mid-ocean ridge magma 973 chamber processes: Insights from the Oman ophiolite. Geochimica et Cosmochimica Acta, 71, 974 p.A611.

975 Monnier, C., Girardeau, J., Le Mee, L. and Polvé, M., 2006. Along-ridge petrological 976 segmentation of the mantle in the Oman ophiolite. Geochemistry, Geophysics, Geosystems, $9777(11)$.

978 Morales, L.F., Boudier, F. and Nicolas, A., 2011. Microstructures and crystallographic preferred 979 orientation of anorthosites from Oman ophiolite and the dynamics of melt lenses. Tectonics, $98030(2)$.

981 Morgan, J.P. and Chen, Y.J., 1993. The genesis of oceanic crust: Magma injection, hydrothermal 982 circulation, and crustal flow. Journal of Geophysical Research: Solid Earth, 98(B4), pp.62839836297.

984 Müller, T., 2016. A petrological and geochemical cross section of lower crust at the Wadi 985 Gideah (Samail ophiolite): implications for the crustal accretion at fast-spreading mid-ocean 986 ridges (Doctoral dissertation, Hannover: Gottfried Wilhelm Leibniz Universität Hannover).

987 Natland, J.H. and Dick, H.J., 1996. Melt migration through high-level gabbroic cumulates of the 988 East Pacific Rise at Hess Deep: the origin of magma lenses and the deep crustal structure of fast989 spreading ridges. In PROCEEDINGS-OCEAN DRILLING PROGRAM SCIENTIFIC RESULTS 990 (pp. 21-58). National Science Foundation.

991 Nicolas, A., Boudier, F. and France, L., 2009. Subsidence in magma chamber and the 992 development of magmatic foliation in Oman ophiolite gabbros. Earth and Planetary Science 993 Letters, 284(1-2), pp.76-87.

994 Nicolas, A., Boudier, F., Ildefonse, B. and Ball, E., 2000. Accretion of Oman and United Arab 995 Emirates ophiolite-Discussion of a new structural map. Marine Geophysical Researches, 21(3), 996 pp.147-180.

997 Nicolas, A., Boudier, F., Koepke, J., France, L., Ildefonse, B. and Mevel, C., 2008. Root zone of 998 the sheeted dike complex in the Oman ophiolite. Geochemistry, Geophysics, Geosystems, 9(5).

999 Nicolas, A. and Ildefonse, B., 1996. Flow mechanism and viscosity in basaltic magma chambers. 1000 Geophysical Research Letters, 23(16), pp.2013-2016. 
1001 Niu, Y., 2004. Bulk-rock major and trace element compositions of abyssal peridotites:

1002 implications for mantle melting, melt extraction and post-melting processes beneath mid-ocean

1003 ridges. Journal of Petrology, 45(12), pp.2423-2458.

1004 Pallister, J.S. and Gregory, R.T., 1983. Composition of the Samail ocean crust. Geology, 11(11), 1005 pp.638-642.

1006 Pallister, J.S. and Hopson, C.A., 1981. Samail ophiolite plutonic suite: field relations, phase 1007 variation, cryptic variation and layering, and a model of a spreading ridge magma chamber.

1008 Journal of Geophysical Research: Solid Earth, 86(B4), pp.2593-2644.

1009 Pallister, J.S. and Knight, R.J., 1981. Rare-earth element geochemistry of the Samail ophiolite 1010 near Ibra, Oman. Journal of Geophysical Research: Solid Earth, 86(B4), pp.2673-2697.

1011 Pálmason, G., 1973. Kinematics and heat flow in a volcanic rift zone, with application to 1012 Iceland. Geophysical Journal International, 33(4), pp.451-481.

1013 Pearce, J.A. and Peate, D.W., 1995. Tectonic implications of the composition of volcanic arc 1014 magmas. Annual review of Earth and planetary sciences, 23, pp.251-286.

1015 Perk, N.W., Coogan, L.A., Karson, J.A., Klein, E.M. and Hanna, H.D., 2007. Petrology and 1016 geochemistry of primitive lower oceanic crust from Pito Deep: implications for the accretion of 1017 the lower crust at the Southern East Pacific Rise. Contributions to Mineralogy and Petrology, 1018 154(5), pp.575-590.

1019 Quick, J.E. and Denlinger, R.P., 1993. Ductile deformation and the origin of layered gabbro in 1020 ophiolites. Journal of Geophysical Research: Solid Earth, 98(B8), pp.14015-14027.

1021 Reagan, M. K., Heaton, D.E., Schmitz, M.D., Pearce, J.A., Shervais, J. W. and Koppers, A.A.P., 1022 2019. Forearc ages reveal extensive short-lived and rapid seafloor spreading following 1023 subduction initiation. Earth and Planetary Science Letters 506, 520-529.

1024 Reagan, M. K., Ishizuka, O., Stern, R. J., Kelley, K. A., Ohara, Y., Blichert-Toft, J., et al., 2010. 1025 Fore-arc basalts and subduction initiation in the Izu-Bonin-Mariana system. Geochemistry, 1026 Geophysics, Geosystems 11, Q03X12.

1027 Rioux, M., Bowring, S., Kelemen, P., Gordon, S., Dudás, F. and Miller, R., 2012. Rapid crustal 1028 accretion and magma assimilation in the Oman-UAE ophiolite: High precision U-Pb zircon 1029 geochronology of the gabbroic crust. Journal of Geophysical Research: Solid Earth, 117(B7).

1030 Roeder, P.L. and Emslie, R., 1970. Olivine-liquid equilibrium. Contributions to mineralogy and 1031 petrology, 29(4), pp.275-289.

1032 Rollinson, H., 2005. Chromite in the mantle section of the Oman ophiolite: a new genetic model. 1033 Island Arc, 14(4), pp.542-550.

1034 
1035 Ross, K. and Elthon, D., 1997. Cumulus and postcumulus crystallization in the oceanic crust: major-and trace-element geochemistry of Leg 153 gabbroic rocks. In Proceedings-Ocean Drilling Program Scientific Results (pp. 333-350). NATIONAL SCIENCE FOUNDATION. Magmatic response to subduction initiation: Part 1. Fore-arc basalts of the Izu-Bonin arc from IODP Expedition 352. Geochemistry, Geophysics, Geosystems 20, 334-338. https://doi. org/10.1029/2018GC007731.

1048 Thompson, R.N., 1987. Phase-equilibria constraints on the genesis and magmatic evolution of 1049 oceanic basalts. Earth-Science Reviews, 24(3), pp.161-210.

1050 Tilton, G.R., Hopson, C.A. and Wright, J.E., 1981. Uranium-lead isotopic ages of the Samail 1051 ophiolite, Oman, with applications to Tethyan ocean ridge tectonics. Journal of Geophysical 1052 Research: Solid Earth, 86(B4), pp.2763-2775.

1053 Urann, B.M., Dick, H.J.B., Parnell-Turner, R. and Casey, J.F., 2020. Recycled arc mantle 1054 recovered from the Mid-Atlantic Ridge. Nature communications, 11(1), pp.1-9.

1055 VanTongeren, J.A., Hirth, G.R.E.G. and Kelemen, P.B., 2015. Constraints on the accretion of the 1056 gabbroic lower oceanic crust from plagioclase lattice preferred orientation in the Samail

1057 ophiolite. Earth and Planetary Science Letters, 427, pp.249-261.

1058 VanTongeren, J.A., Kelemen, P.B. and Hanghøj, K., 2008. Cooling rates in the lower crust of the 1059 Oman ophiolite: Ca in olivine, revisited. Earth and Planetary Science Letters, 267(1-2), pp.69106082.

1061 VanTongeren, J.A., Mathez, E.A. and Kelemen, P.B., 2010. A felsic end to Bushveld 1062 differentiation. Journal of Petrology, 51(9), pp.1891-1912.

1063 Wanless, V.D. and Behn, M.D., 2017. Spreading rate-dependent variations in crystallization 1064 along the global mid-ocean ridge system. Geochemistry, Geophysics, Geosystems, 18(8), 1065 pp.3016-3033.

1066 Wanless, V.D. and Shaw, A.M., 2012. Lower crustal crystallization and melt evolution at mid1067 ocean ridges. Nature Geoscience, 5(9), pp.651-655.

1068 White, R.S., McKenzie, D. and O'Nions, R.K., 1992. Oceanic crustal thickness from seismic 1069 measurements and rare earth element inversions. Journal of Geophysical Research: Solid Earth, 1070 97(B13), pp.19683-19715. 
1071 Wood, B.J. and Blundy, J.D., 1997. A predictive model for rare earth element partitioning 1072 between clinopyroxene and anhydrous silicate melt. Contributions to Mineralogy and Petrology, 1073 129(2), pp.166-181.

1074 Workman, R.K. and Hart, S.R., 2005. Major and trace element composition of the depleted

1075 MORB mantle (DMM). Earth and Planetary Science Letters, 231(1-2), pp.53-72.

1076

1077

1078

1079

1080

1081

1082

1083

1084

1085

1086

1087

1088

1089

1090

1091

1092

1093

1094

1095

1096

1097

1098

1099

1100

1101

1102

1103

1104

1105

1106

1107

1108

1109

1110

1111

1112

1113

1114

1115

Figure 1. Stratigraphic units in the Penrose model of fast-spreading oceanic crust for an approximately $7 \mathrm{~km}$ thick oceanic crust, similar to that of W. Khafifah in the southern Samail ophiolite. Stratigraphic height of samples from this study denoted by stars. Stratigraphic distinction between 'Layered Gabbro', 'Transitional Gabbro', and 'High-level Gabbro' from Pallister and Hopson (1981).

Figure 2. Large-scale map of the Oman ophiolite, adapted from Nicolas et al. (2000). Areas in orange (gabbro) and red (sheeted dikes and lavas) indicate oceanic crustal sections; areas in grey are mantle peridotite. Inset shows the location of W. Khafifah (this study) and W. Gideah (GT1 and GT2 drillcore site from the Oman Drilling Project), from Pallister and Hopson (1981).

Figure 3. Plagioclase An content and clinopyroxene Mg\# in oceanic gabbros from this study (W. Khafifah), Hess Deep, East Pacific Rise, from Lissenberg et al. (2013) and Natland and Dick (1996), and Pito Deep, East Pacific Rise, from Perk et al. (2007). W. Khafifah gabbros overlap with the range found in extant ridges, but typically have slightly higher plagioclase An for a

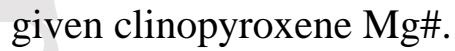

Figure 4. Thin section photomicrographs in crossed polarized light of representative samples from the upper gabbros and lower gabbros. Note significant change in the textural character of the samples from lower gabbro to upper gabbro. Top row: (a) OM97-114, DMTZ $=4367 \mathrm{~m}$, abundant plagioclase and pyroxene with no olivine; (b) OM97-113, DMTZ = $3989 \mathrm{~m}$, greater modal abundance of pyroxene as compared with sample OM97-114. Bottom row: (c) OM97-95, DMTZ = $2303 \mathrm{~m}$, pyroxene, plagioclase, and cumulus olivine; (d) OM97-67, DMTZ = $46 \mathrm{~m}$, similar in character to OM97-95, though slightly lower modal abundance of olivine present.

Figure 5. Whole rock major element variation with stratigraphic height above the Mantle Transition Zone (MTZ) in meters. See Table 2 for data. Lower gabbros in solid black, upper gabbros in open circles, average sheeted dike composition shown in grey triangle, with standard deviation as black line.

Figure 6. Whole rock trace element variation with stratigraphic height above the MTZ (m). Lower gabbros in solid black circles, upper gabbros in open circles, average sheeted dike composition shown in grey triangle, with standard deviation as black line. Note that no sheeted dike information is plotted for the incompatible trace elements, due to their extreme enrichment in the sheeted dike samples relative to the gabbros. See Table 2 for data.

Figure 7. Mineral major element variation with stratigraphic height above the MTZ (m). Lower gabbros in solid black circles, upper gabbros in open circles.

This article is protected by copyright. All rights reserved. 
1116 Figure 8. Mineral trace element variation with stratigraphic height above the MTZ (m). Lower gabbros in solid black, upper gabbros in open symbols.

Figure 9. Enrichment Factor (E) calculated according to equation 1 (see text). (a) E calculated using whole rock $\mathrm{Zr}$ content vs. stratigraphic height. (b) Correlation between E calculated from whole rock $\mathrm{Zr}$ vs. calculated from whole rock $\mathrm{P}_{2} \mathrm{O}_{5}$.

Figure 10. Percent difference calculated between the calculated whole rock value (from mineral compositions and modes; see eqn. 2 in text) and measured whole rock values. $\%$ Difference $=$ $100 *$ [ $\left.\mathrm{WR}_{\text {calculated }}-\mathrm{WR}_{\text {measured }}\right] / \mathrm{WR}_{\text {measured. }}$ Larger percent difference seen in the upper gabbros is likely due to mineral zoning and/or presence of intercumulus material along grain boundaries.

Figure 11. Similarity between the liquid calculated to be in equilibrium with the lower gabbros, and the measured whole rock composition of the upper gabbros and sheeted dikes. Measured whole rock data from lower gabbros in solid black circles, from upper gabbros in open circles. Sheeted dike compositions are shown in filled yellow triangles; liquids calculated to be in equilibrium with lower gabbros are plotted in filled red circles. (a) Equilibrium liquid $\mathrm{Fe}^{2+} / \mathrm{Mg}_{\text {molar }}$ calculated from olivine, note there is no cumulus olivine present in the upper gabbros. Sheeted dike $\mathrm{Fe}^{2+} / \mathrm{Mg}_{\text {molar }}$ calculated assuming $\mathrm{Fe}^{3+} / \mathrm{Fe}_{\text {total }}=0.16$ (Cottrell and Kelly, 2011). (b) Equilibrium liquid Ce (ppm) calculated from clinopyroxene in lower and upper gabbros, see Table 8 for full REE dataset.

Figure 12. Full trace element dataset for lower gabbros (solid black circles), upper gabbros (open circles), and sheeted dikes (yellow). (a) whole rock trace elements normalized to primitive mantle from Sun and McDonough (1995); (b) whole rock REE normalized to C1 chondrite (Sun and McDonough, 1995).

Figure 13. Comparison of changes in mineral major element chemistry with height above the MTZ between Hess Deep (EPR; open triangles) from Lissenberg et al. (2013) and W. Khafifah (this study; black circles). Both Plagioclase An content and clinopyroxene Mg\# from Lissenberg are the averages measured.

Figure 14. A new model for the accretion of the lower oceanic crust. 'Gabbro Glacier' model based on (Sleep, 1975; Nicolas et al., 1989; Quick and Denlinger, 1993; Phipps Morgan and Chen, 1993; Henstock et al., 1993). 'Sheeted Sills: Original' based on Kelemen et al. (1997). 'Hybrid: Boudier' refers to the model of Boudier (1997), and 'Hybrid: Maclennan' refers to the model of Maclennan et al. (2004). 'Full Sheeted Sills' model is proposed in this study, melts derived directly from the mantle are shown in red, yellow regions correspond to evolved melt emplaced in the upper gabbros after fractional crystallization in the lower gabbros. The axial magma chamber beneath the sheeted dikes contains melts derived from the crystallization of the upper gabbros and subsequently erupted to the seafloor. See text for full descriptions. Factor (E) calculated in this study. Obliquity (alpha) is measured as the angle between the plagioclase b-axis (010) maxima to the modal layering in the sample (see cartoon inset 'a'), data from VanTongeren et al. (2015).

This article is protected by copyright. All rights reserved. 
1163 Figure 16. Whole rock compositions from this study compared to mid ocean ridge basalts and 1164 estimates of primitive melt of the MORB mantle. Large circles correspond to lower gabbros 1165 (black fill) and upper gabbros (white fill) from W. Khafifah (this study). Small black circles 1166 correspond to lower gabbros from the GT1 drillcore in nearby Wadi Gideah (data from Kelemen 1167 et al., 2020a). Small white circles correspond to upper gabbros from the uppermost $50 \mathrm{~m}$ of the 1168 GT2 drillcore (data from Kelemen et al., 2020b) and gabbros and diorites from the lowermost $1169180 \mathrm{~m}$ of the GT3 drillcore (data from Kelemen et al., 2020c). Open triangles are sheeted dike 1170 compositions from W. Tayin (this study). The average bulk plutonic crust from W. Khafifah is 1171 in the large red star, and average bulk crust including the sheeted dikes as the extrusive layer for 1172 W. Khafifah is represented by the large blue star, see Table 9 for details. Grey circles labeled 1173 "EPR, seg avg, Gale13" are segment averages from the East Pacific Rise from Gale et al. (2013). 1174 Large grey circle is the average of all MORB determined by Gale et al. (2013). The large orange 1175 star is the bulk plutonic crust estimate for Hess Deep from Gillis et al. (2013). The large yellow 1176 circle is 14\% aggregated fractional mantle melt from the experiments of Kinzler and Grove 1177 (1992).

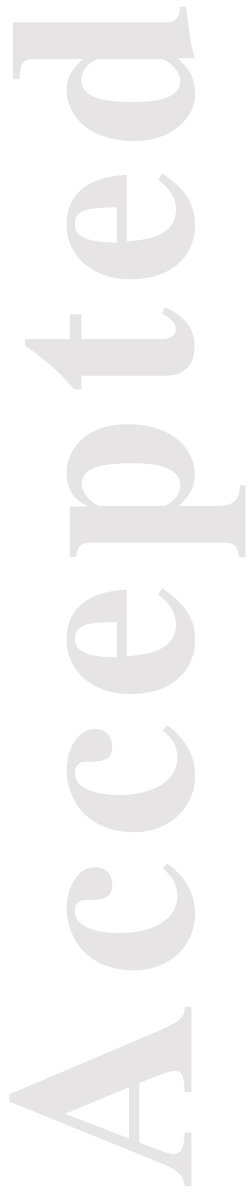

This article is protected by copyright. All rights reserved. 


\section{Penrose Structure}

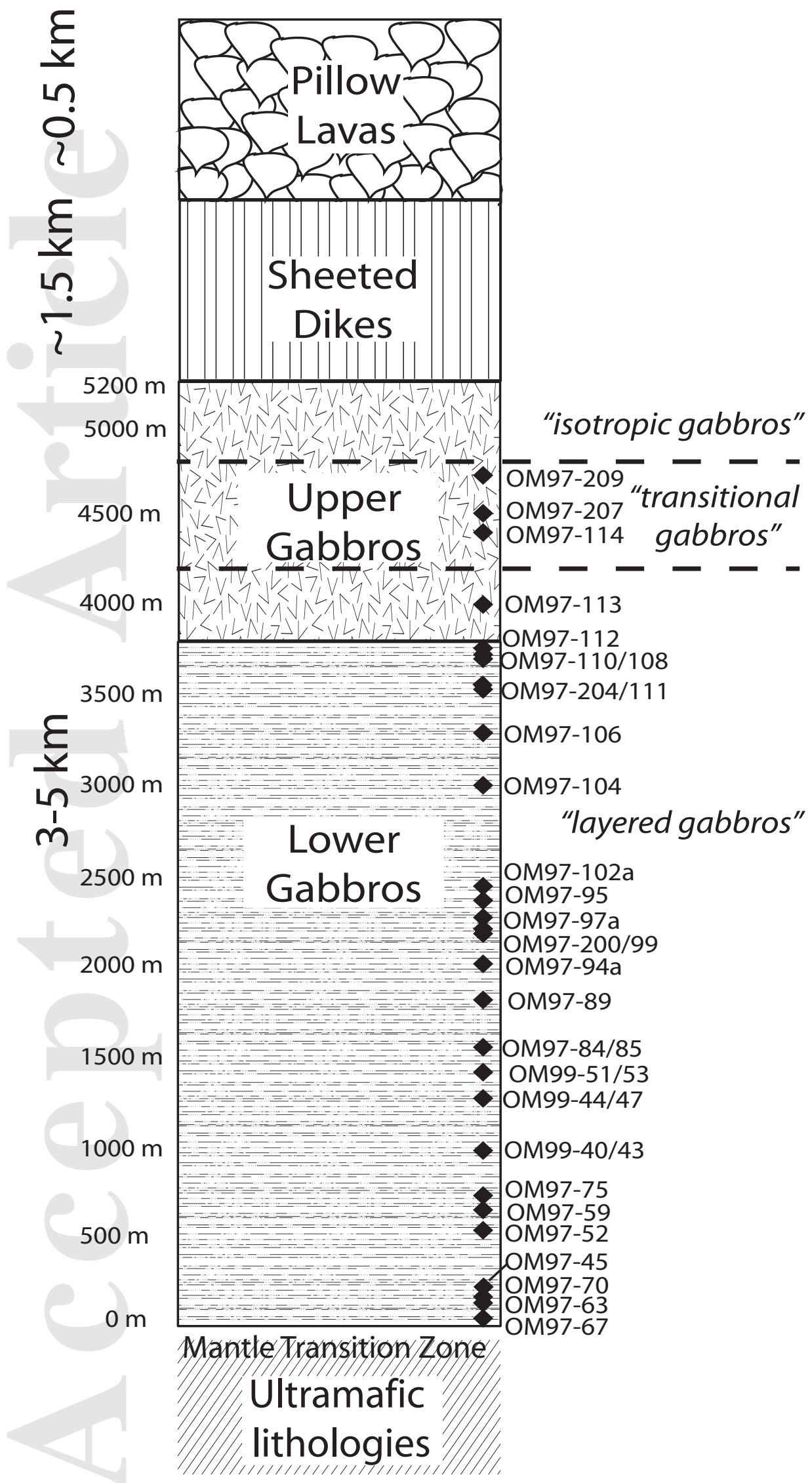

This article is protected by copyright. All rights reserved. 


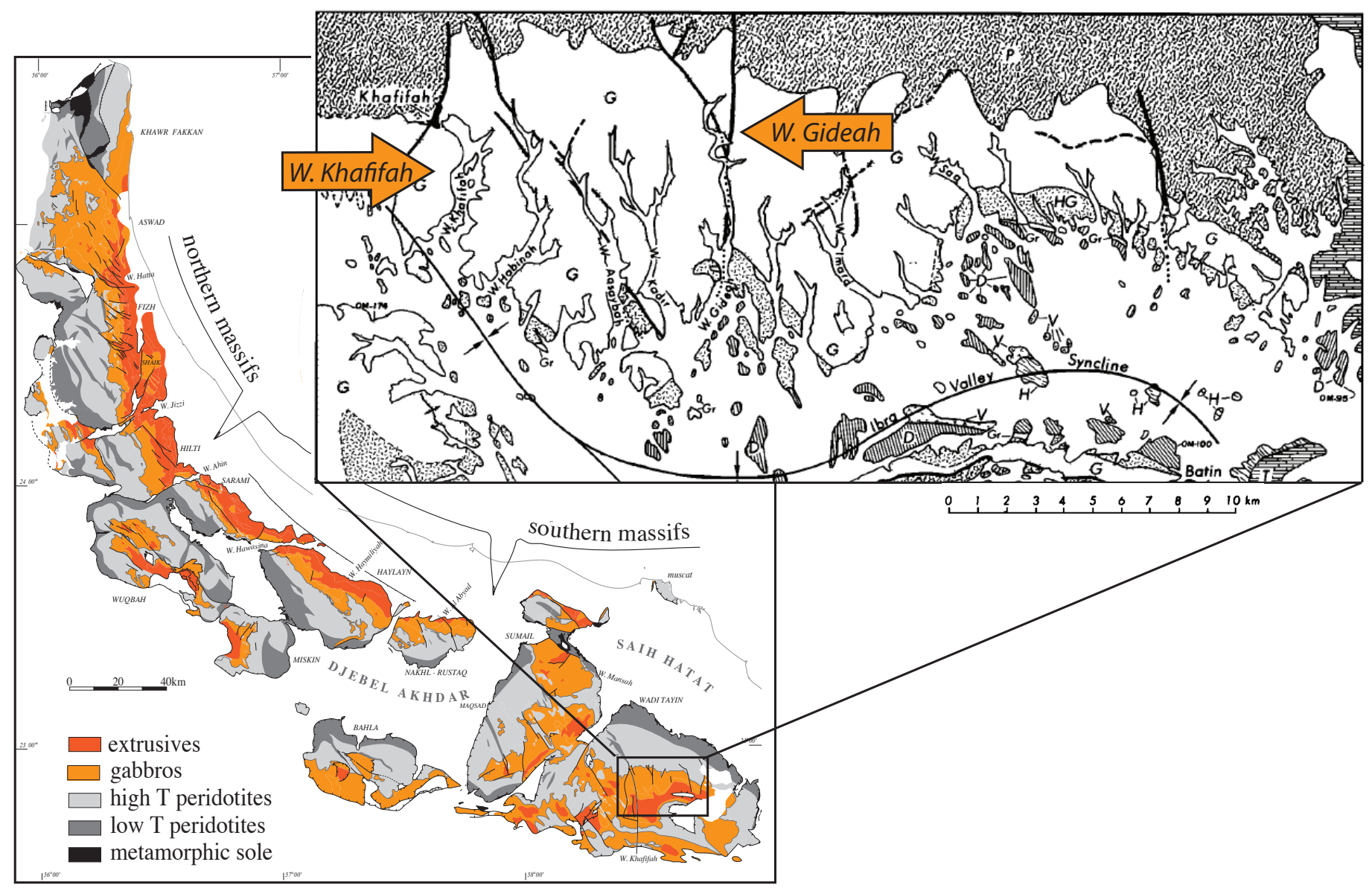




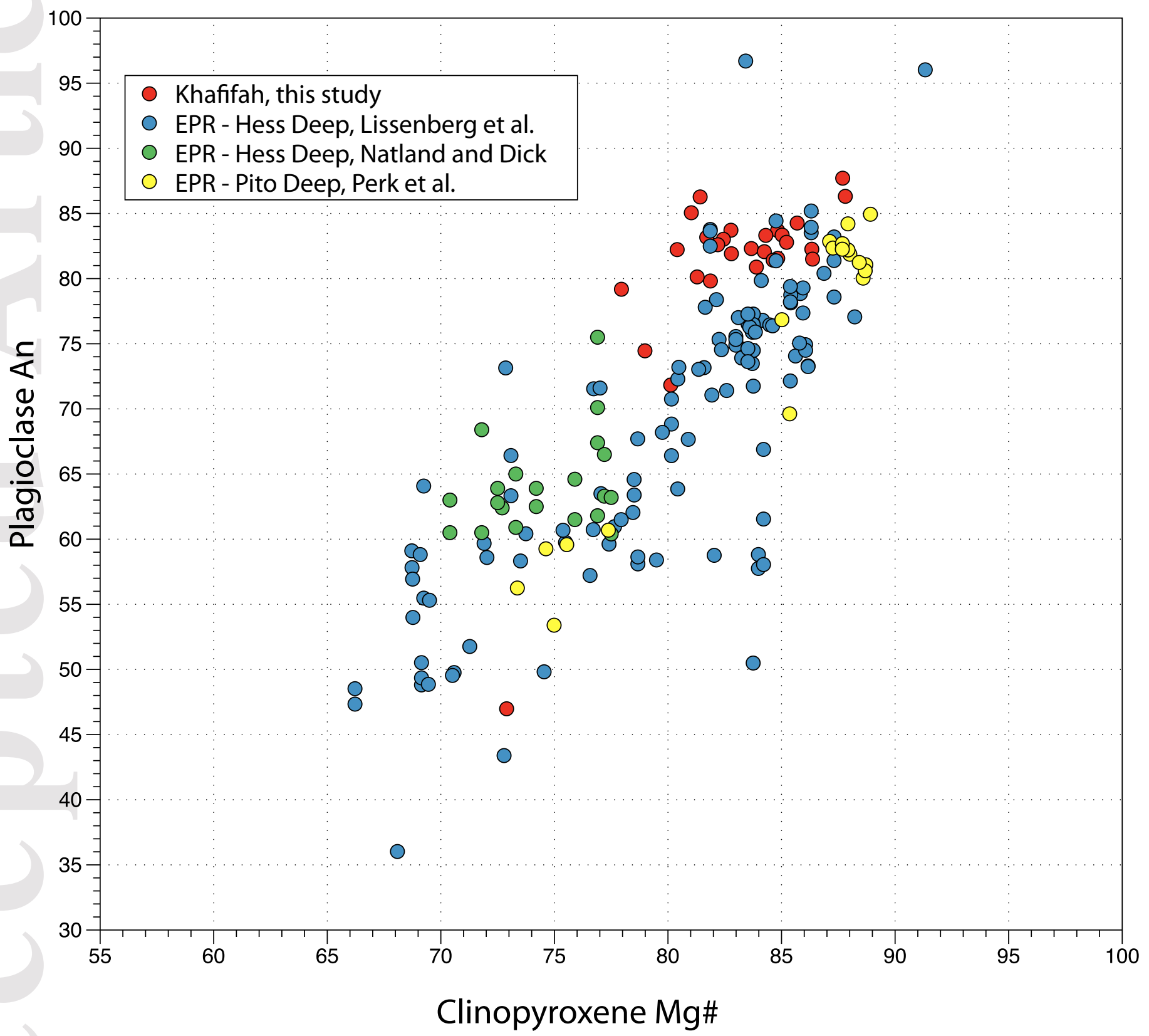

This article is protected by copyright. All rights reserved. 
(a) OM97-114; DMTZ $=4367 \mathrm{~m}$

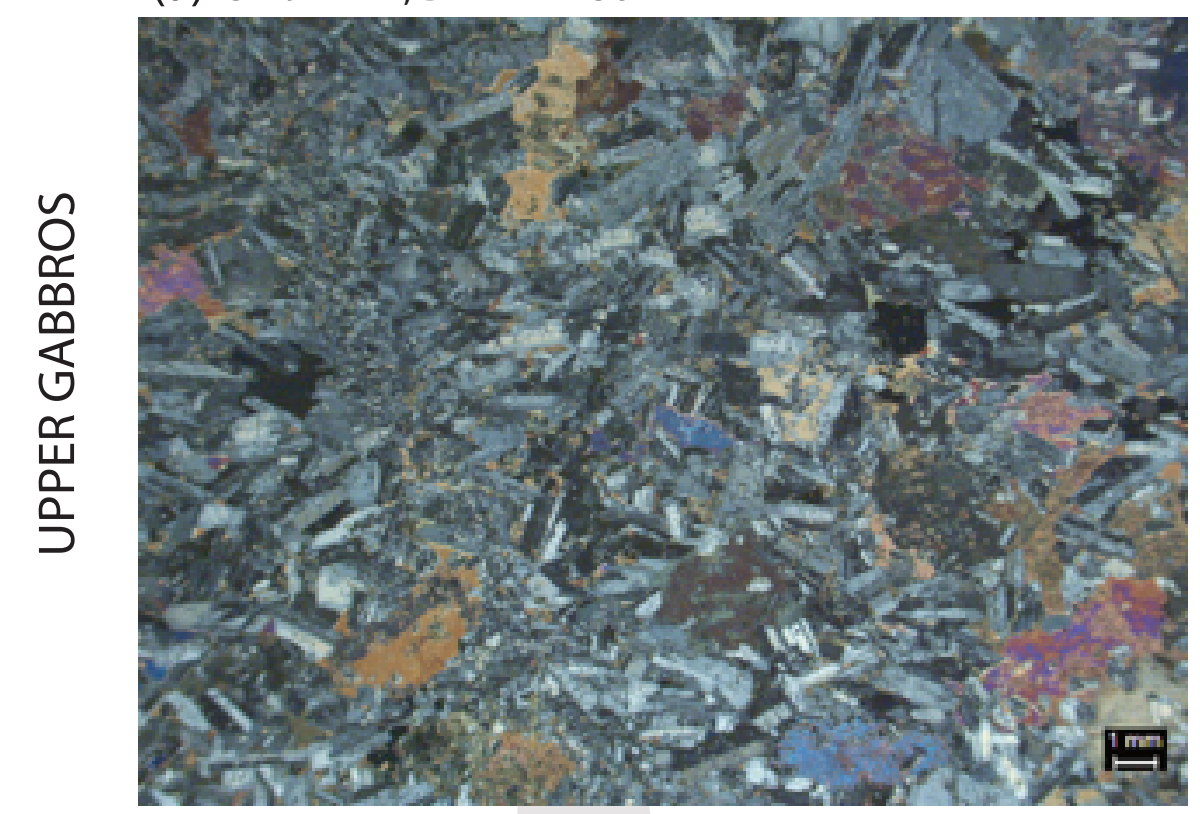

\section{$(+3)$}

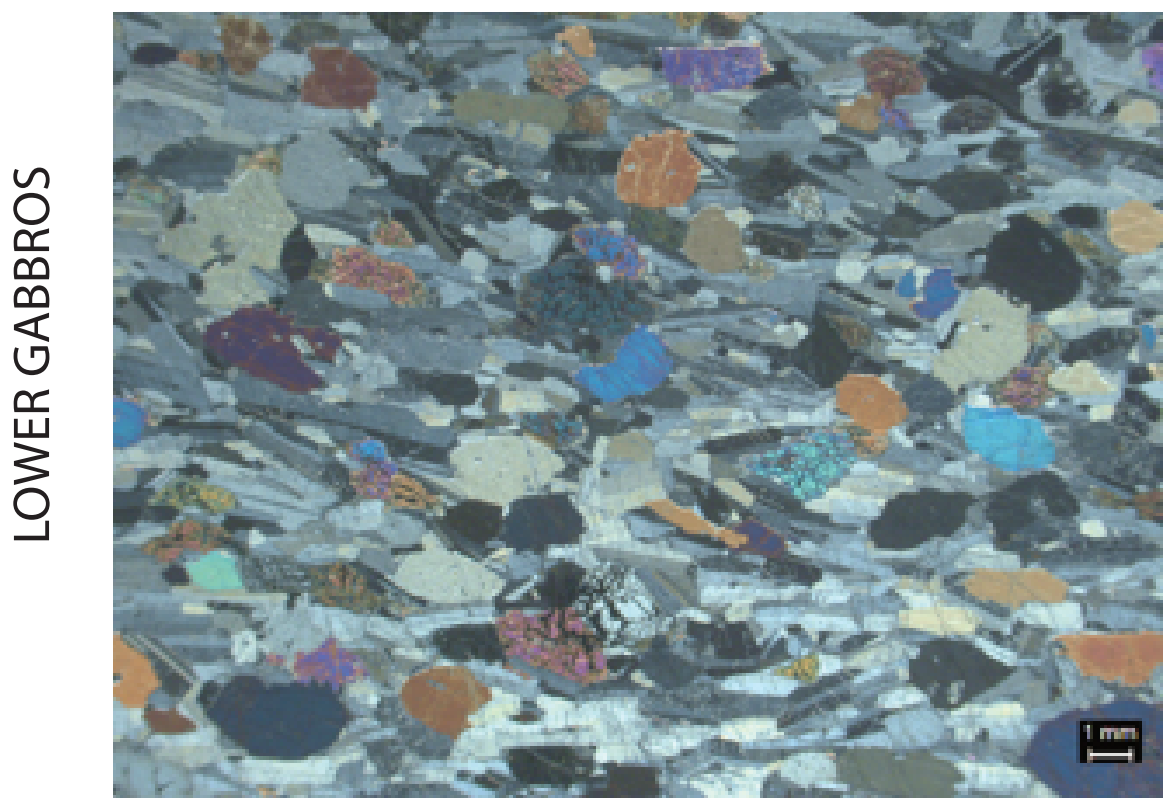

(c) OM97-95; DMTZ = $2303 \mathrm{~m}$ (b) OM97-113; DMTZ = $3989 \mathrm{~m}$
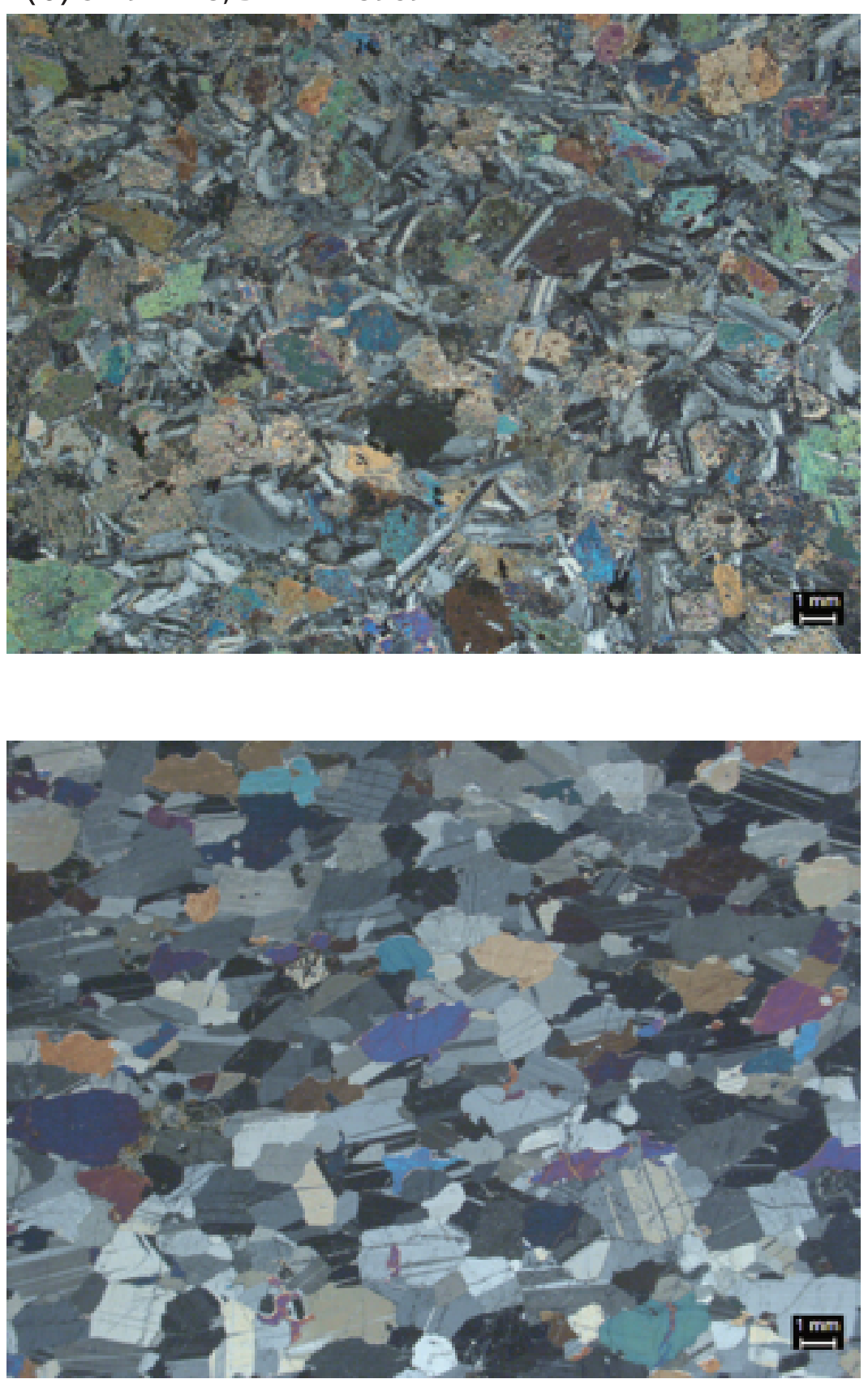

(d) OM97-67; DMTZ = $46 \mathrm{~m}$

This article is protected by copyright. All rights reserved. 

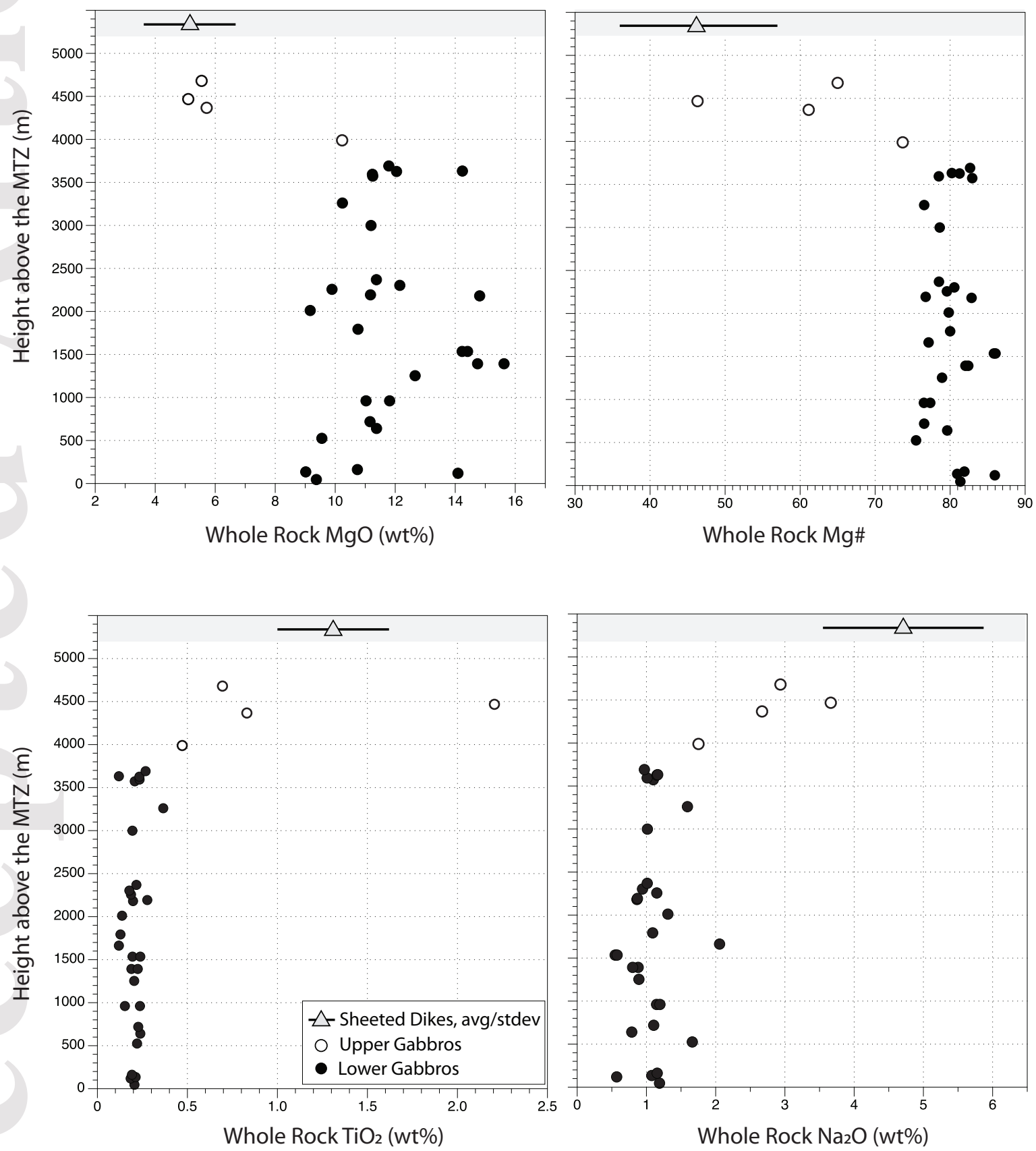

This article is protected by copyright. All rights reserved. 

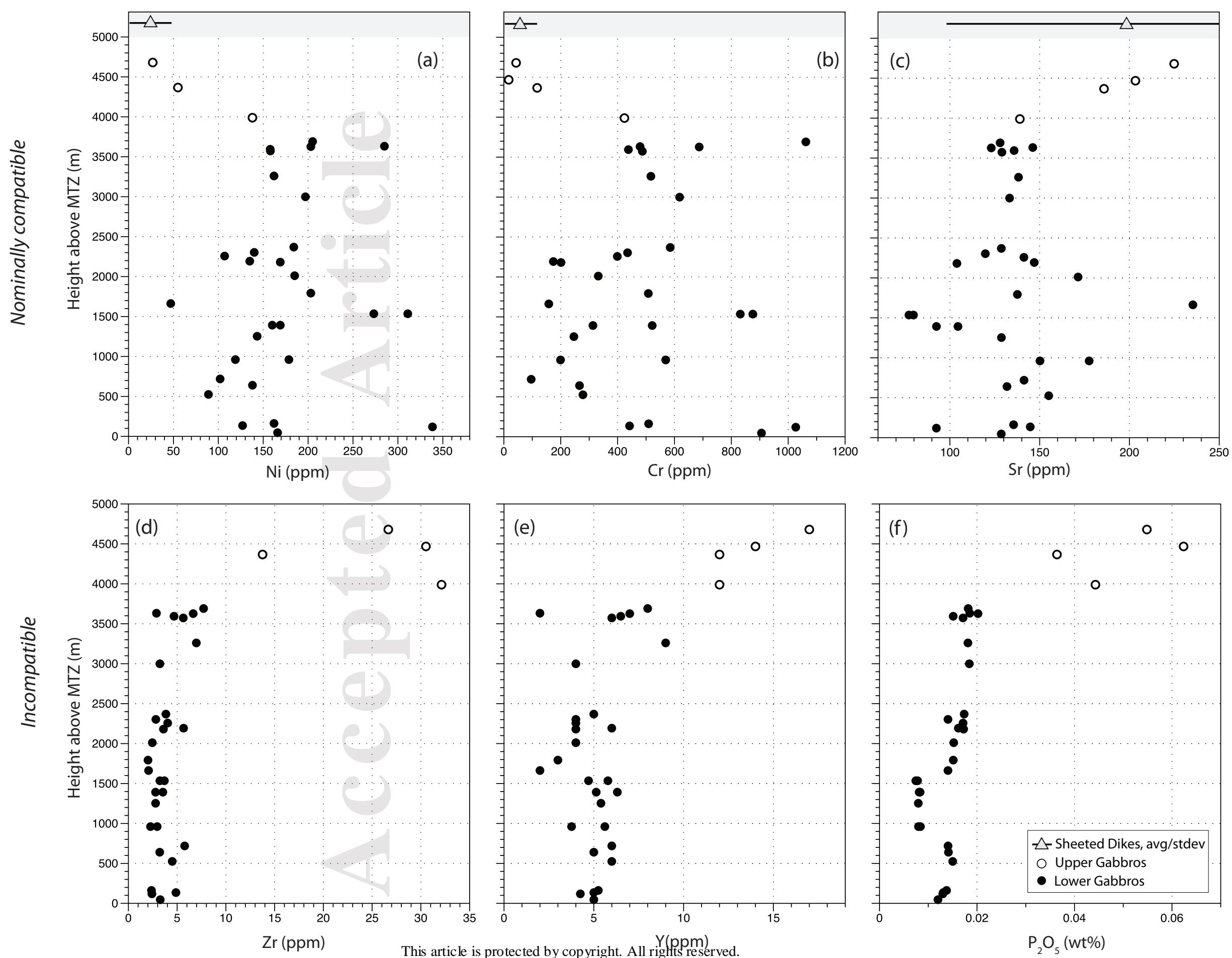

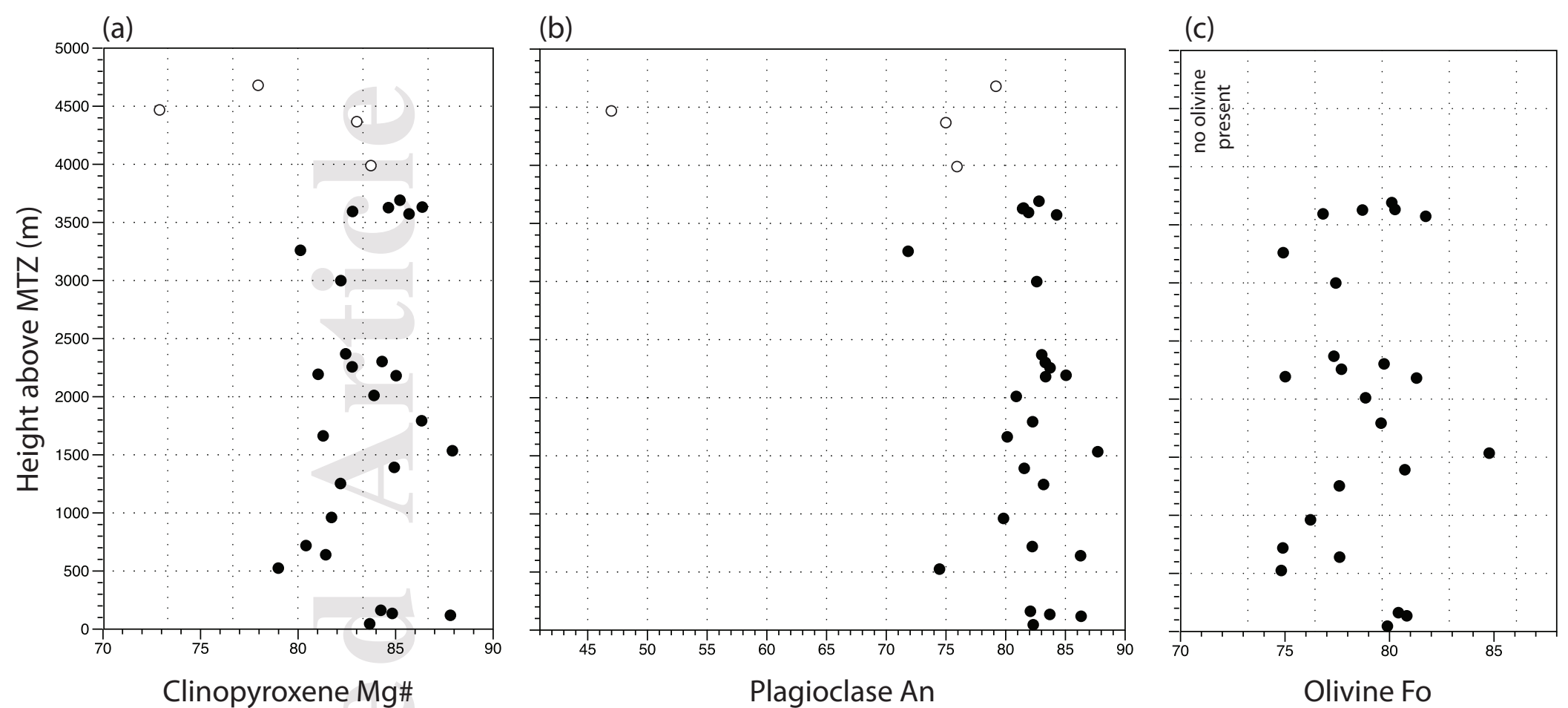

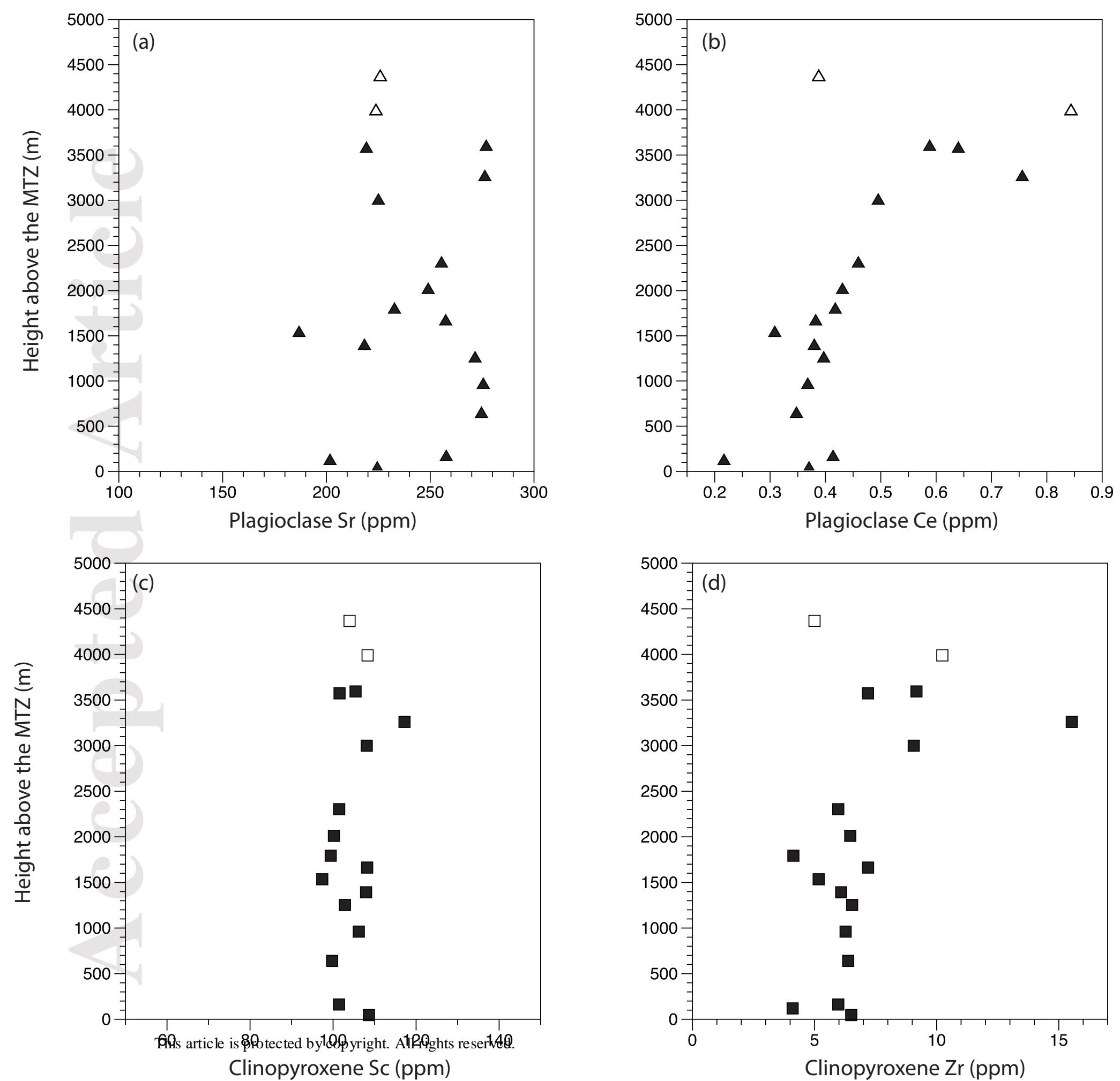

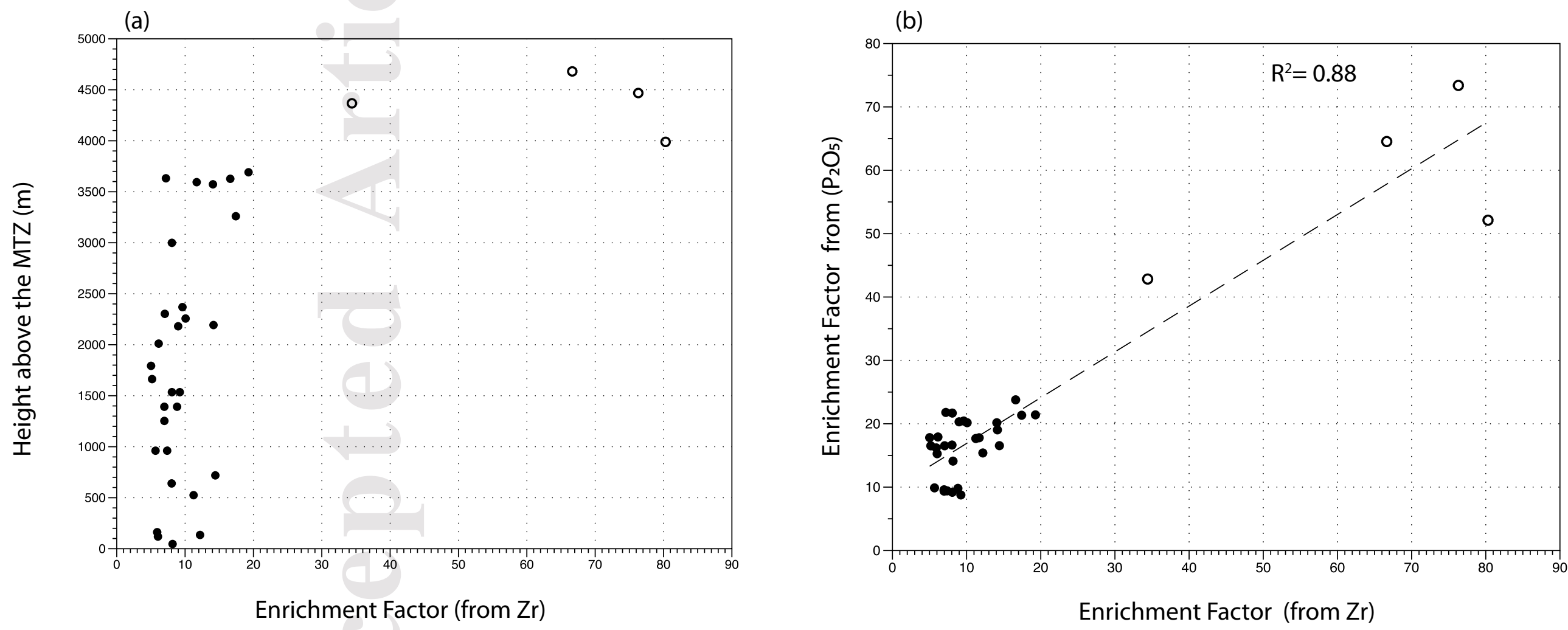
(a)

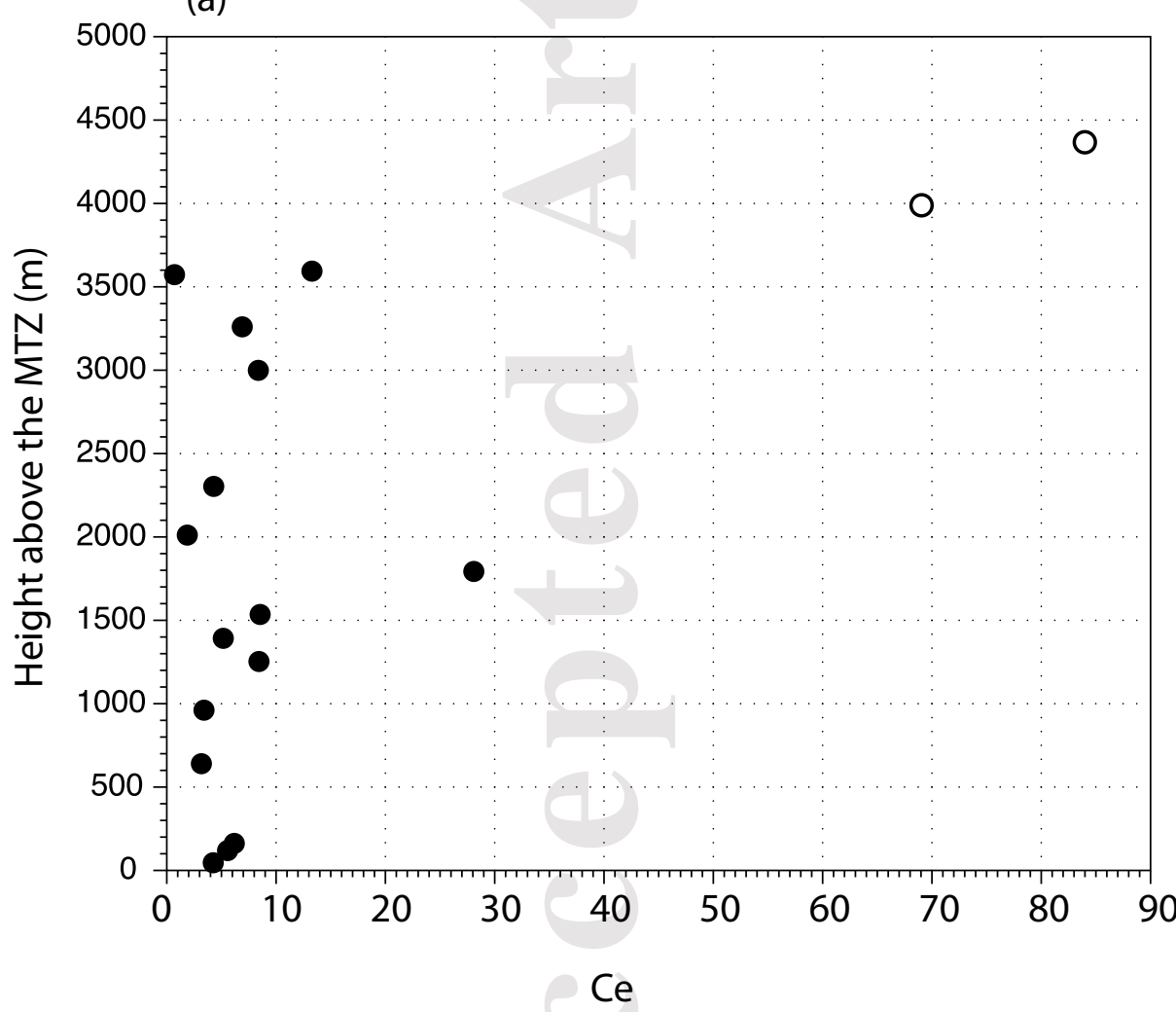

(b)

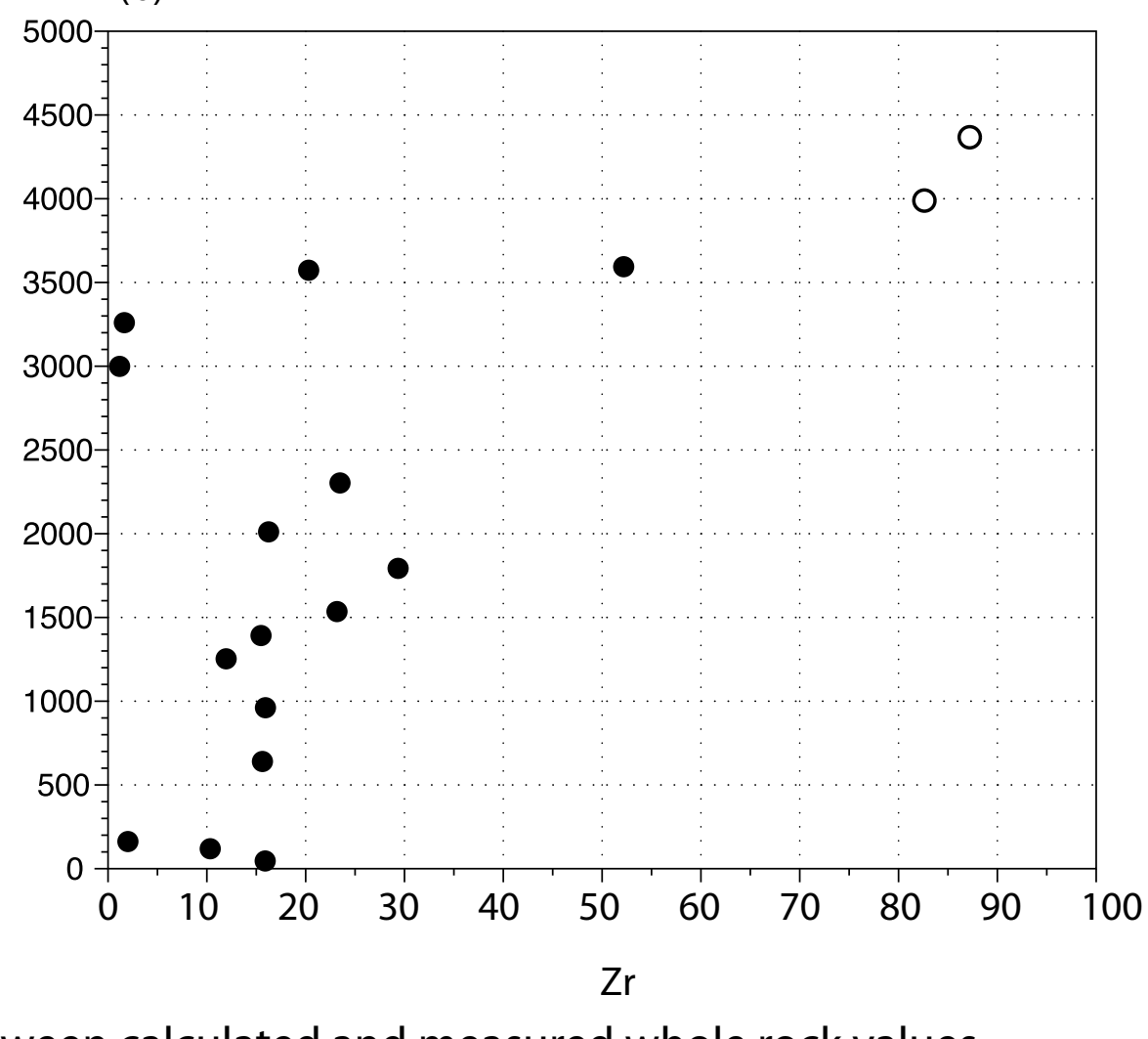

Difference (Enrichment) between calculated and measured whole rock values 
(a)

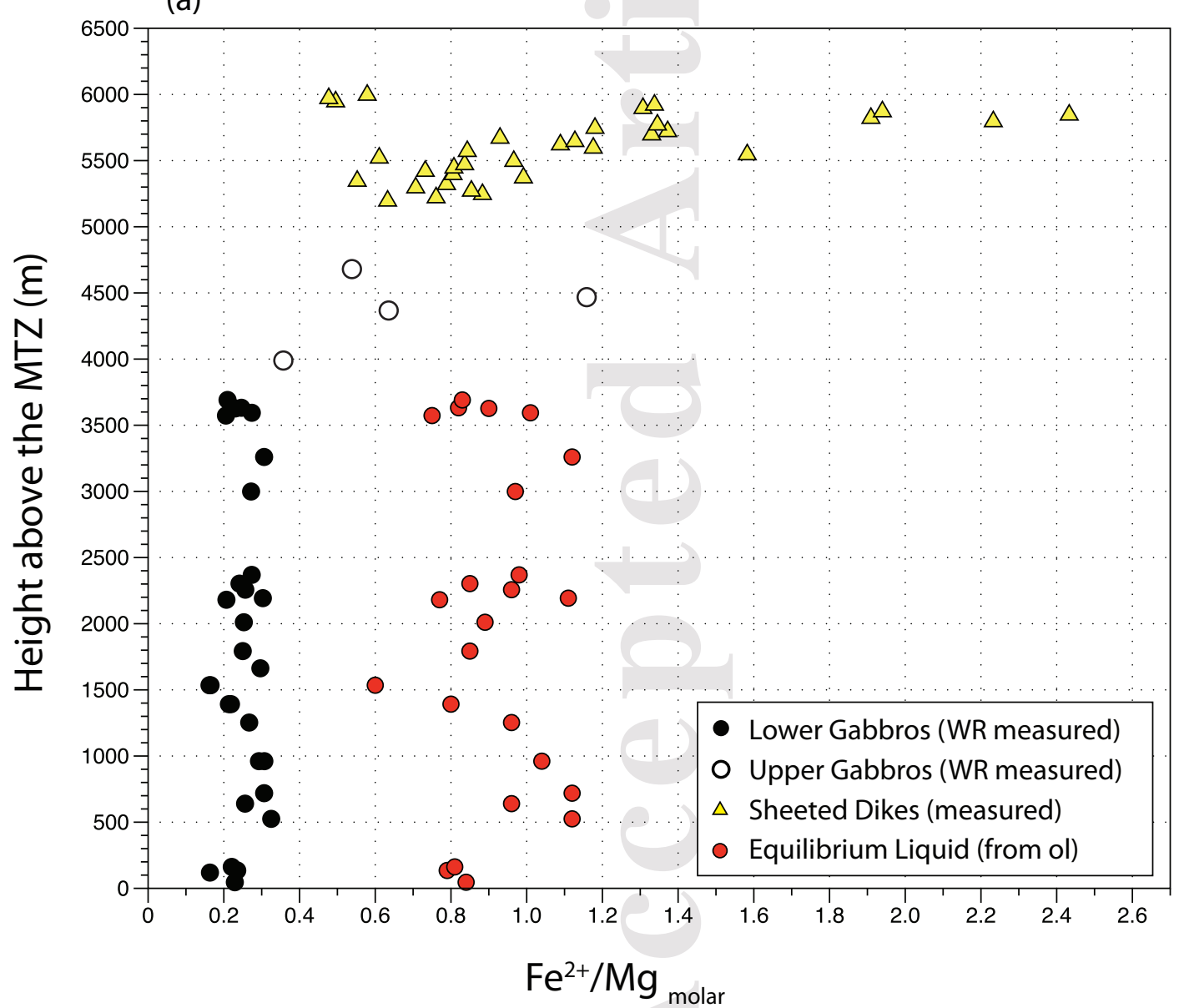

(b)

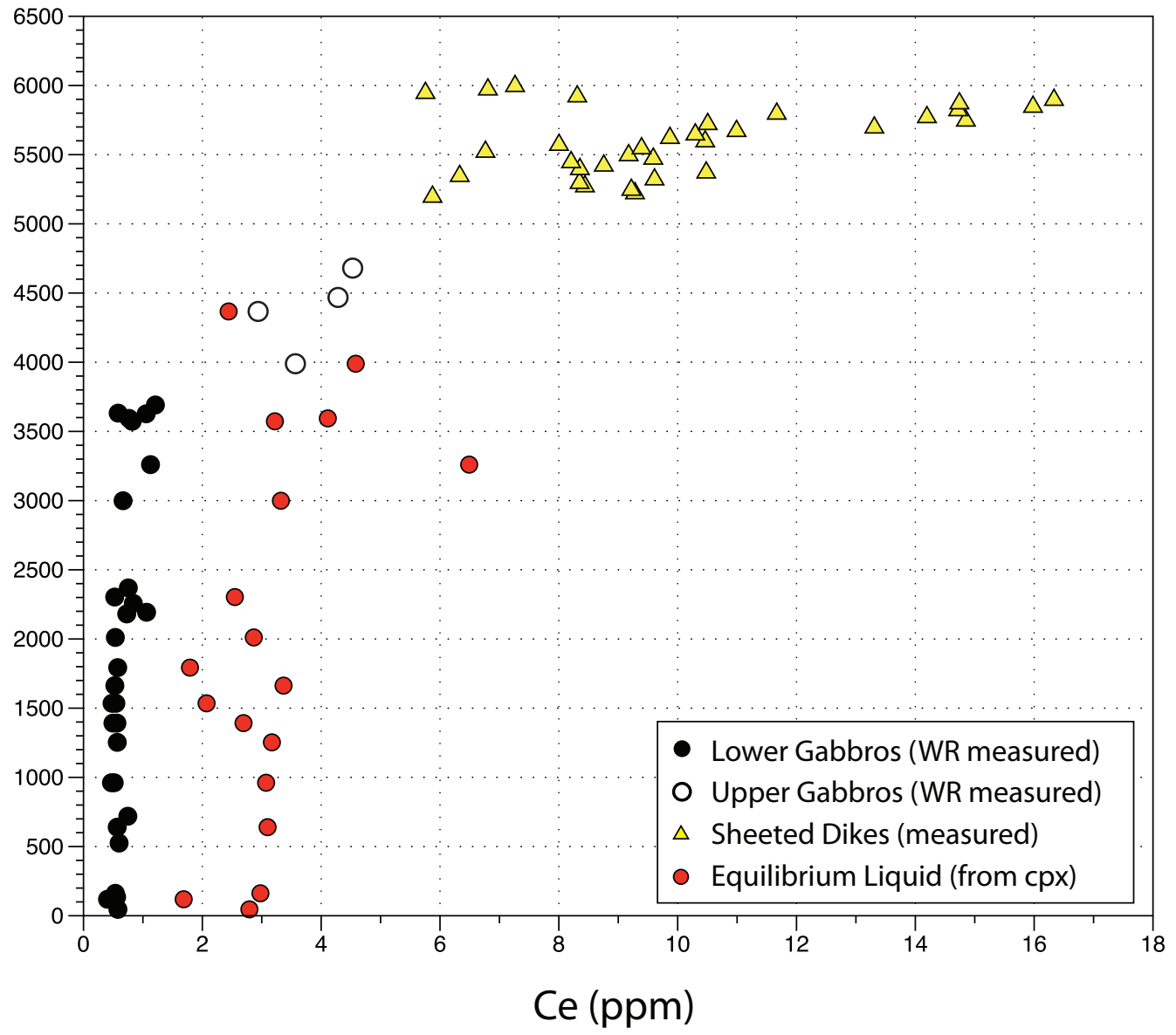


(a)

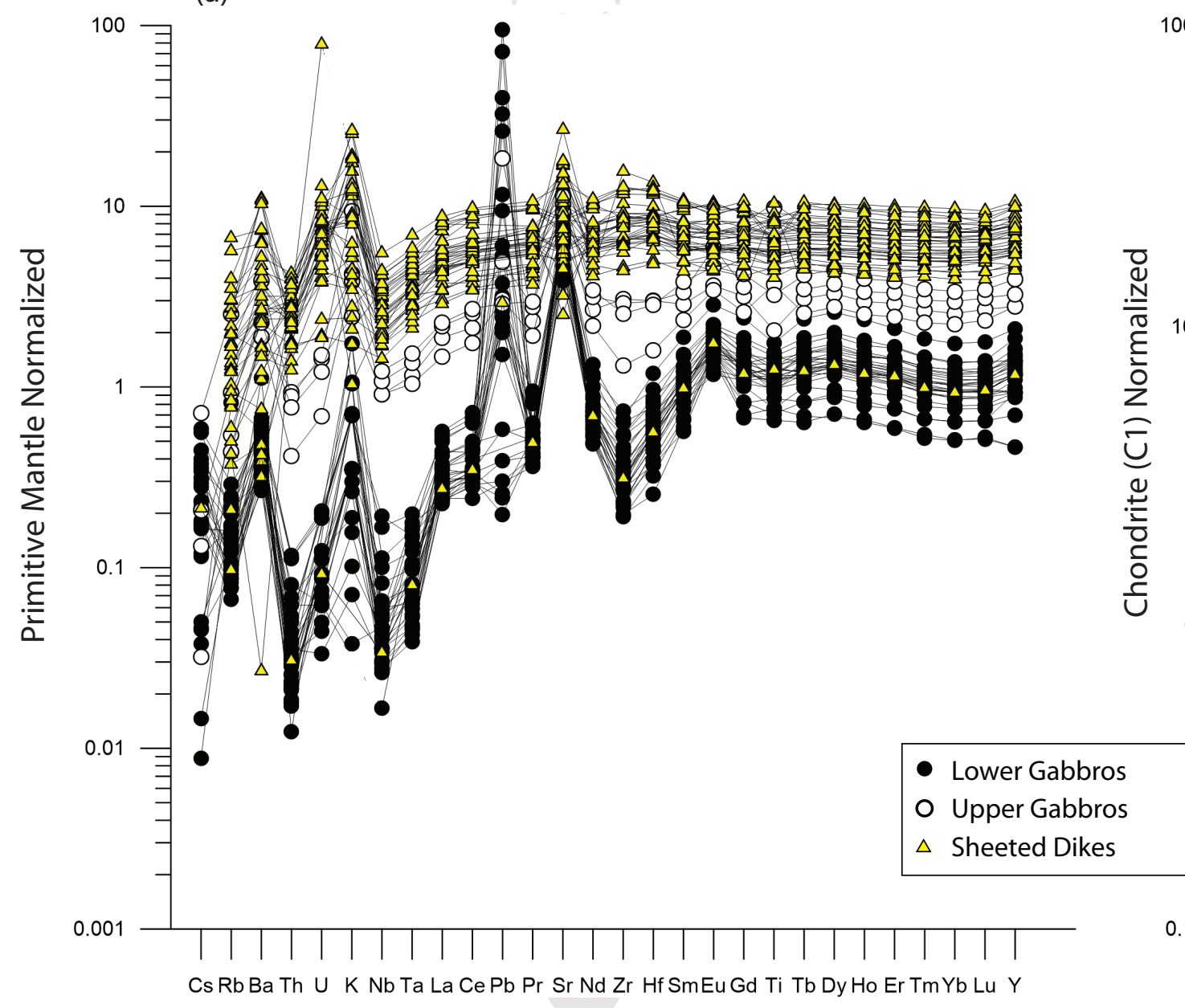

(b)

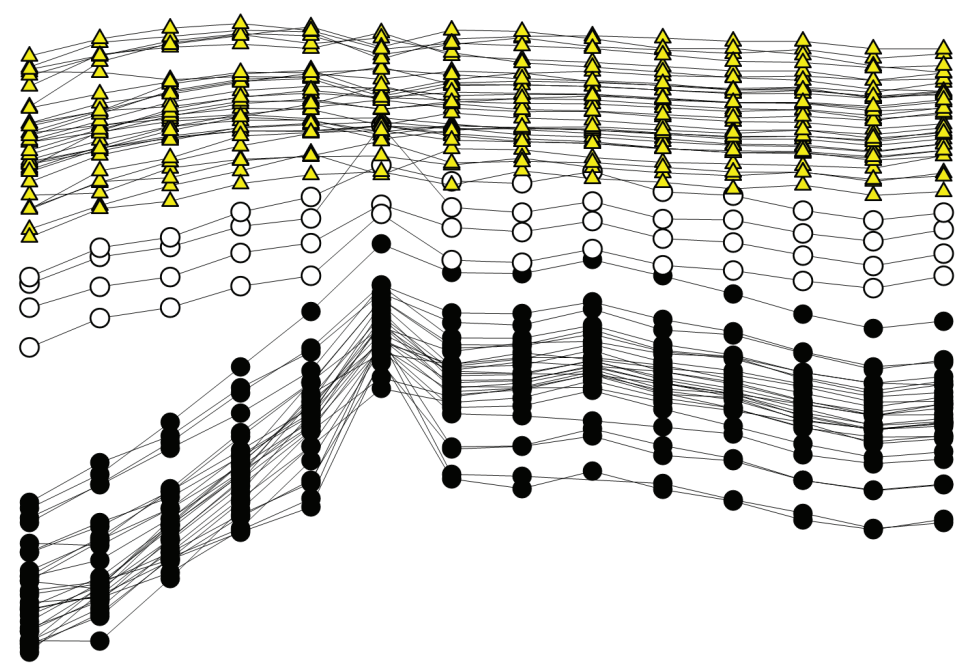

0.1

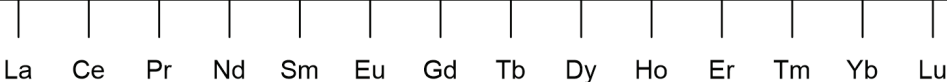




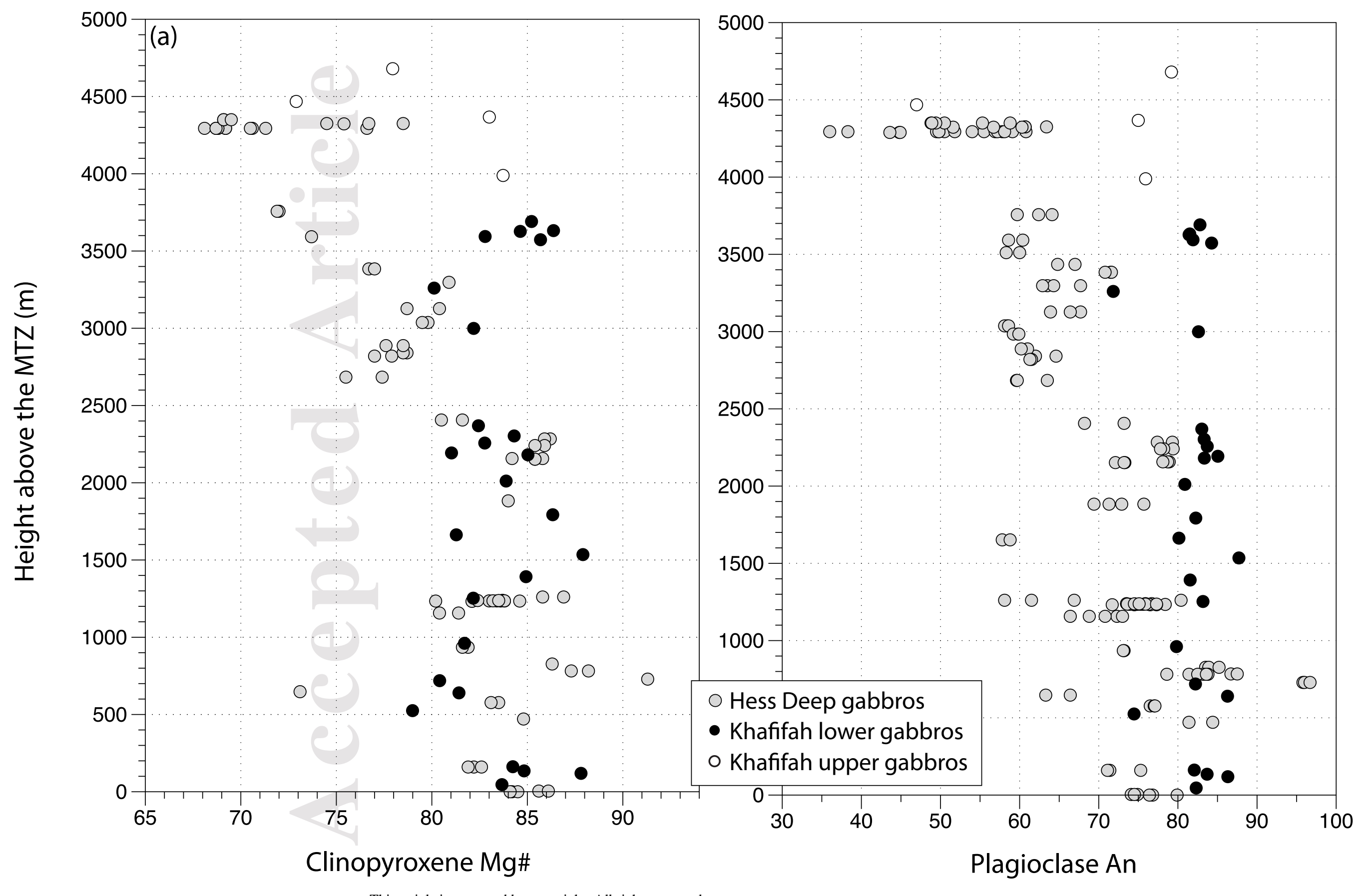

This article is protected by copyright. All rights reserved. 


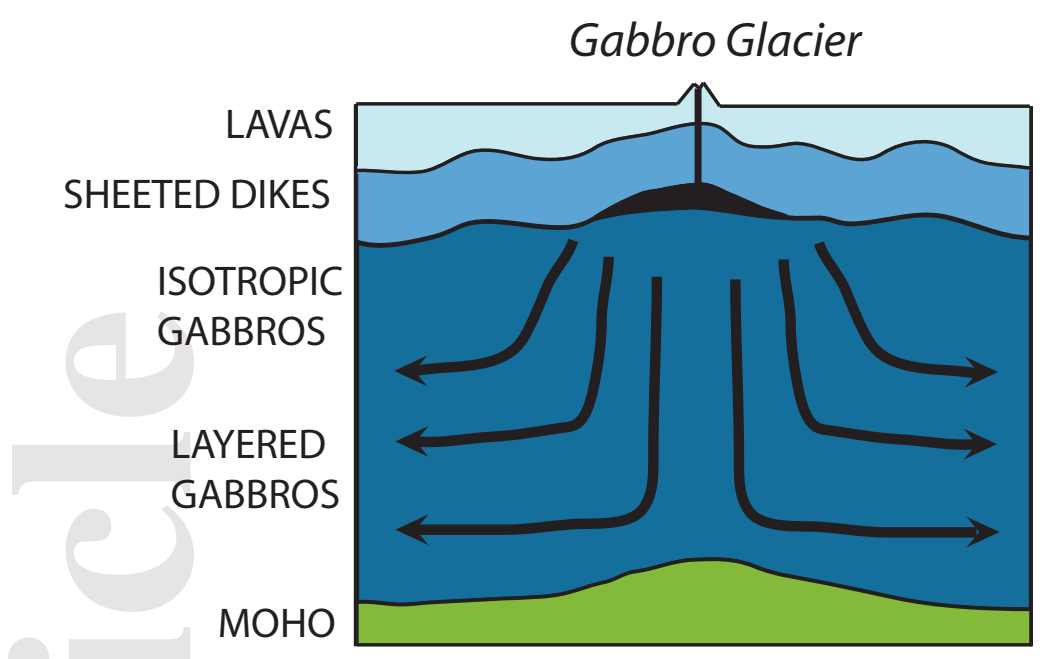

Hybrid:Boudier

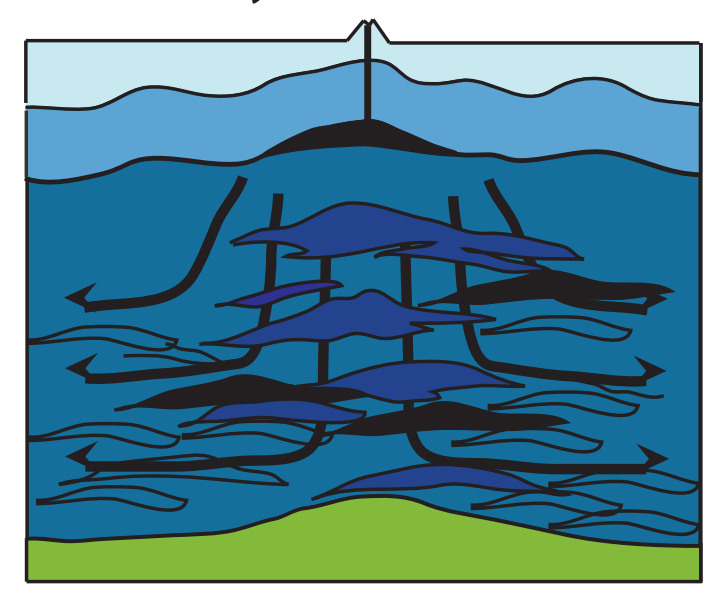

Full Sheeted Sills: This study

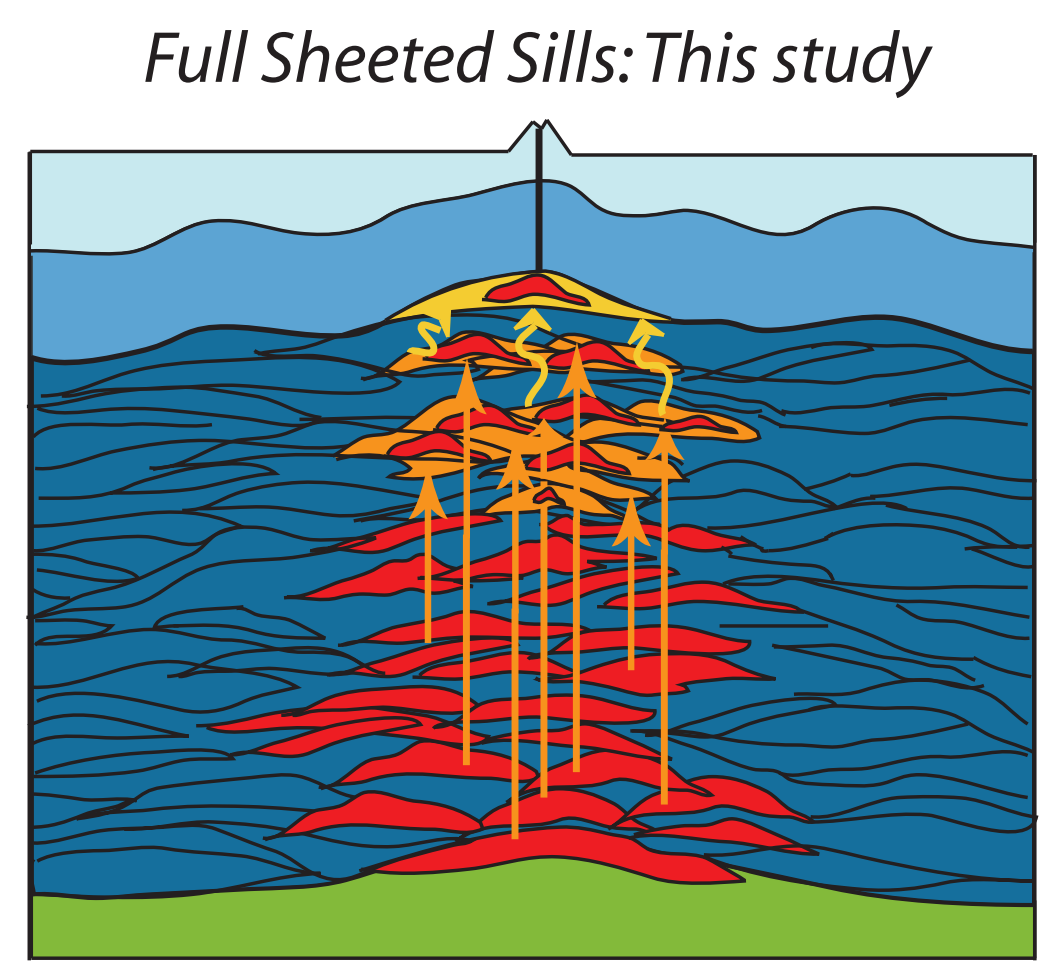

Sheeted Sills: Original

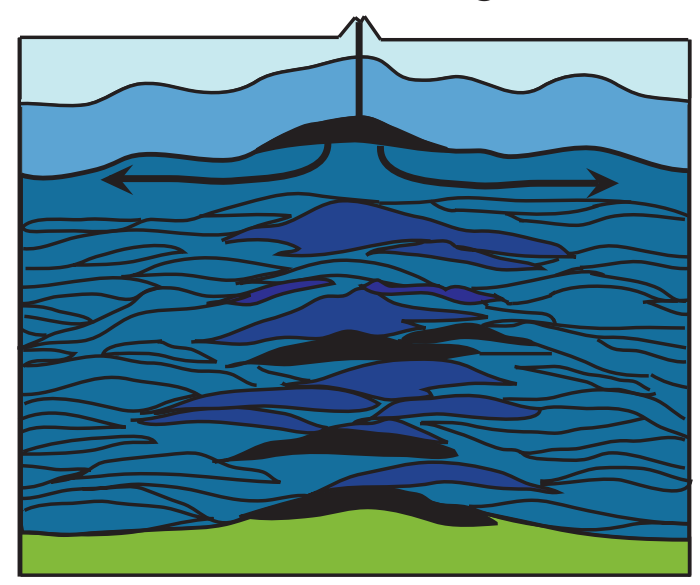

Hybrid:Maclennan/Mock

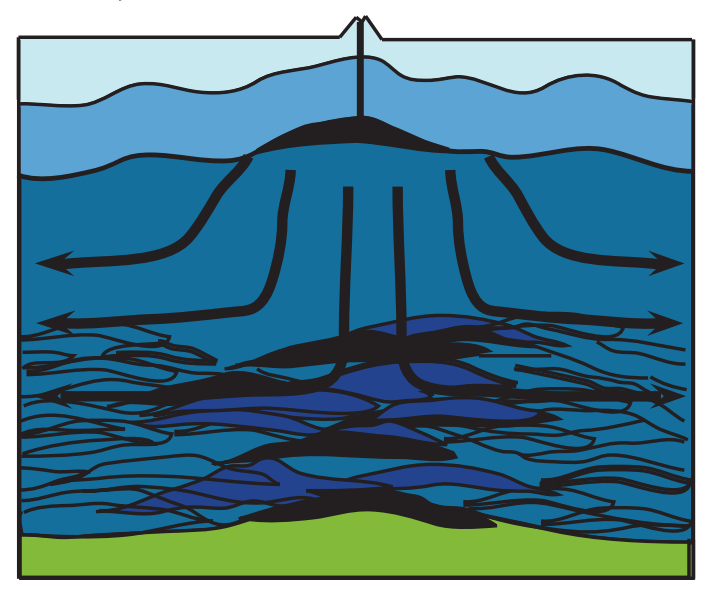

This article is protected by copyright. All rights reserved. 
(a)

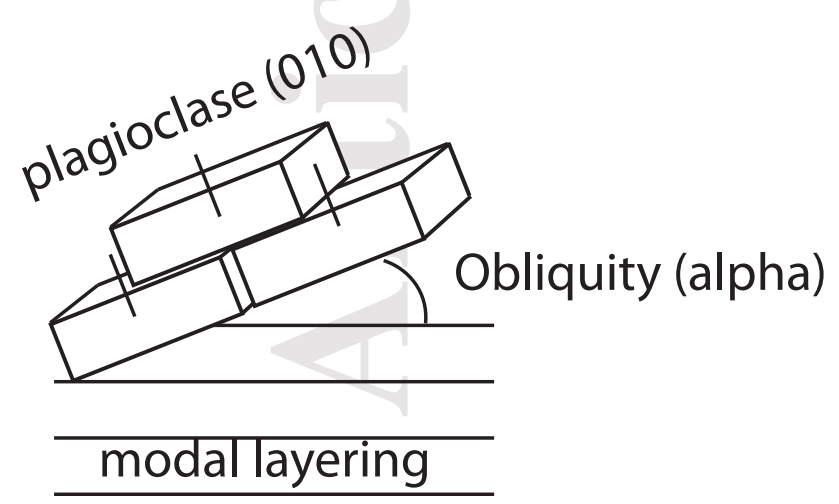

(b)

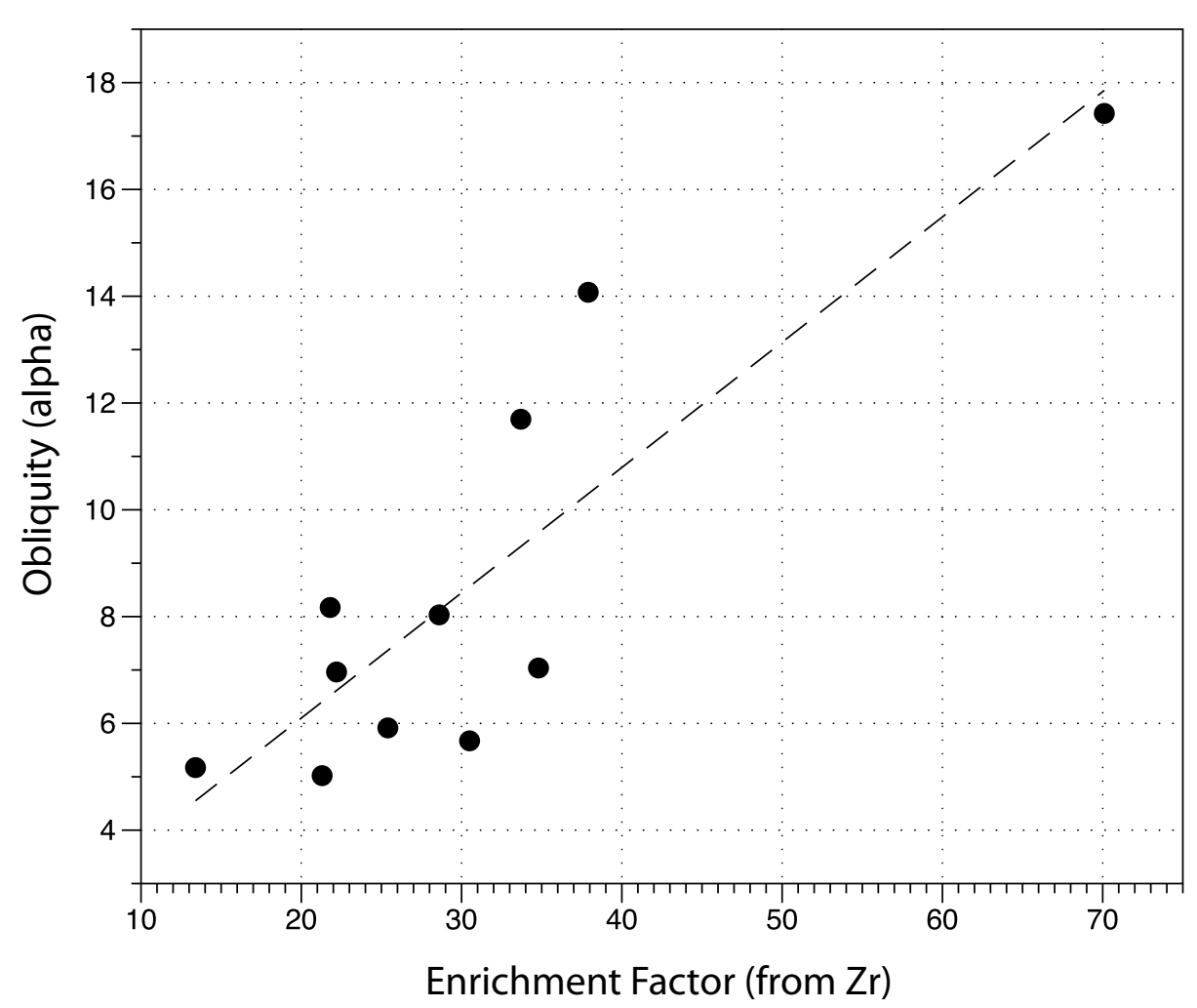




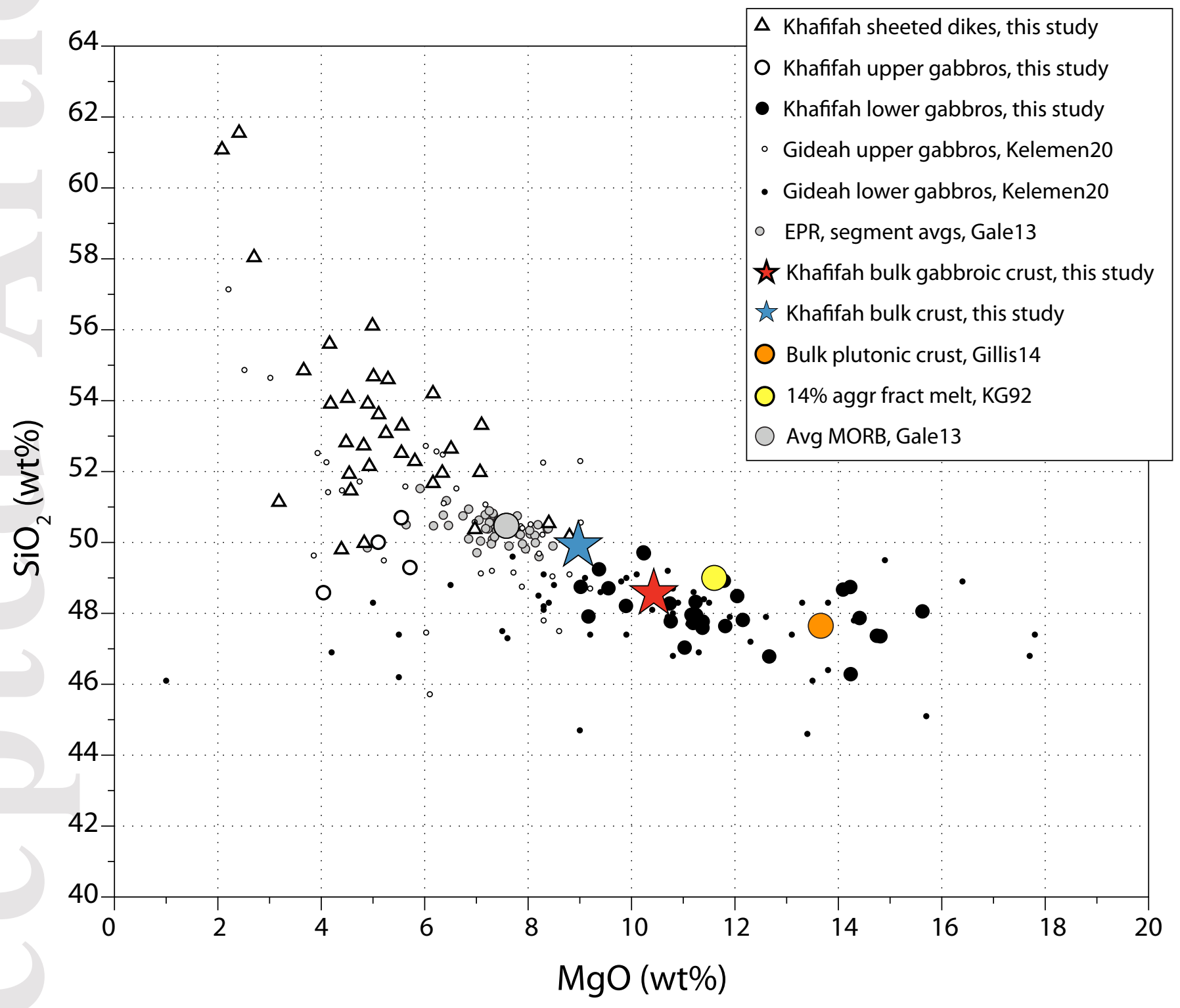

This article is protected by copyright. All rights reserved. 
Table 1a. Sample Locations and Modes for W. Khafifah Gabbros

\begin{tabular}{|c|c|c|c|c|c|c|}
\hline \multicolumn{2}{|c|}{ Sample Numl Lithology } & \multirow[t]{2}{*}{ Collection } & \multicolumn{2}{|l|}{ Height above } & Location & \\
\hline & & & $\mathrm{MTZ}(\mathrm{m})$ & UTM & UTM & Olivine \\
\hline OM97-67a & gabbro & Garrido & 46 & $0650333 \mathrm{E}$ & $2535082 \mathrm{~N}$ & 7 \\
\hline OM97-63 & gabbro & Garrido & 119 & $0650333 \mathrm{E}$ & $2535082 \mathrm{~N}$ & 11 \\
\hline OM97-70 & gabbro & Garrido & 135 & $0650333 \mathrm{E}$ & $2535082 \mathrm{~N}$ & 7 \\
\hline OM97-45 & gabbro & Garrido & 162 & $0647495 \mathrm{E}$ & $2535235 \mathrm{~N}$ & 10 \\
\hline OM97-52 & gabbro & Garrido & 525 & 0647495 & 2535235 & 11 \\
\hline OM97-59a & gabbro & Garrido & 640 & $0647011 \mathrm{E}$ & $2534394 \mathrm{~N}$ & 12 \\
\hline OM97-75 & gabbro & Garrido & 719 & 0646947 & 2534217 & 14 \\
\hline OM99-40 & gabbro & z-gap & 961 & $0646787 \mathrm{E}$ & $2533534 \mathrm{~N}$ & 16 \\
\hline OM99-43 & gabbro & z-gap & 961 & $0646787 \mathrm{E}$ & $2533534 \mathrm{~N}$ & 15 \\
\hline OM99-44 & gabbro & z-gap & 1253 & 0646124 & 2533154 & 16 \\
\hline OM99-47 & gabbro & z-gap & 1392 & $0647213 \mathrm{E}$ & $2532471 \mathrm{~N}$ & 19 \\
\hline OM99-49 & gabbro & z-gap & 1392 & $0647213 \mathrm{E}$ & $2532471 \mathrm{~N}$ & 18 \\
\hline OM99-51 & gabbro & z-gap & 1535 & 0647395 & 2532127 & 14 \\
\hline OM99-53 & gabbro & z-gap & 1535 & 0647395 & 2532127 & 10 \\
\hline OM97-84 & anorthosite & Garrido & 1663 & $0646064 \mathrm{E}$ & $2532410 \mathrm{~N}$ & 2 \\
\hline OM97-85 & gabbro & Garrido & 1663 & $0646064 \mathrm{E}$ & $2532410 \mathrm{~N}$ & \\
\hline OM97-89 & gabbro & Garrido & 1793 & $0647433 \mathrm{E}$ & $2531650 \mathrm{~N}$ & 14 \\
\hline OM97-94a & gabbro & Garrido & 2011 & 0647601 & 2531070 & 10 \\
\hline OM97-200 & gabbro & Garrido & 2181 & 0649566 & 2530116 & 18 \\
\hline OM97-99 & gabbro & Garrido & 2193 & 0649181 & 2530214 & 12 \\
\hline OM97-97a & gabbro & Garrido & 2257 & 0648561 & 2530315 & 10 \\
\hline OM97-95 & gabbro & Garrido & 2303 & 0647632 E & $2530434 \mathrm{~N}$ & 16 \\
\hline OM97-102a & gabbro & Garrido & 2369 & 0649507 & 2529684 & 14 \\
\hline OM97-104 & gabbro & Garrido & 2999 & 0649574 & 2528329 & 14 \\
\hline OM97-106 & gabbro & Garrido & 3260 & 0649106 E & $2527817 \mathrm{~N}$ & 10 \\
\hline OM97-204 & gabbro & Garrido & 3573 & $0648467 \mathrm{E}$ & $2527222 \mathrm{~N}$ & 11 \\
\hline OM97-111 & gabbro & Garrido & 3594 & 0648373 E & $2527198 \mathrm{~N}$ & 13 \\
\hline OM97-110 & gabbro & Garrido & 3627 & 0648348 & 2527124 & 14 \\
\hline OM97-108 & gabbro & Garrido & 3632 & 0648255 & 2527137 & 25 \\
\hline OM97-112 & gabbro & Garrido & 3691 & 0648274 & 2526987 & 11 \\
\hline OM97-113 & gabbro & Garrido & 3989 & 0648812 E & $2526220 \mathrm{~N}$ & 0 \\
\hline OM97-114 & gabbro & Garrido & 4367 & $0649061 \mathrm{E}$ & $2525225 \mathrm{~N}$ & 0 \\
\hline OM97-207 & gabbro & Garrido & 4468 & $0649484 \mathrm{E}$ & $2524862 \mathrm{~N}$ & 0 \\
\hline OM97-209 & gabbro & Garrido & 4680 & 0650895 E & 2523955 E & 0 \\
\hline
\end{tabular}


Modal Abundance (wt\%)

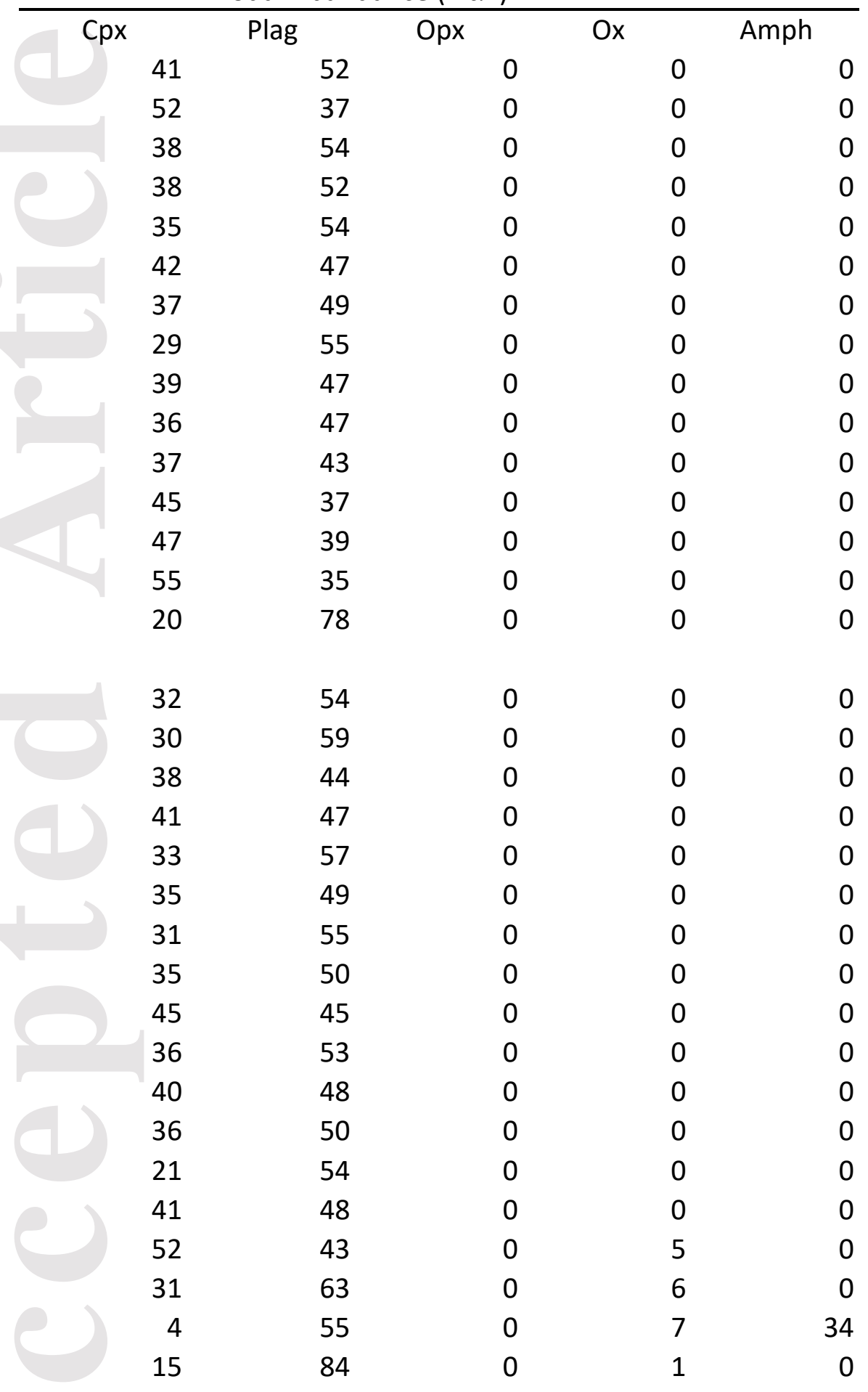

This article is protected by copyright. All rights reserved. 
Table 1b. Sample locations for Sheeted Dike Samples from W. Khafifah

\begin{tabular}{|c|c|c|c|c|}
\hline \multirow[b]{2}{*}{ Sample Number } & \multirow[b]{2}{*}{ Lithology } & \multicolumn{2}{|c|}{ Location } & Orientation \\
\hline & & UTM E & UTM N & Strike \\
\hline OM01-09 & Sheeted Dike & 649193 & 2515356 & $34240 \mathrm{E}$ \\
\hline OM01-10 & Sheeted Dike & 649193 & 2515356 & $334 \mathrm{E}$ \\
\hline OM01-11 & Sheeted Dike & 649193 & 2515356 & $34240 \mathrm{E}$ \\
\hline OM01-12 & Sheeted Dike & 649159 & 2515385 & $34042 \mathrm{E}$ \\
\hline OM01-13 & Sheeted Dike & 649144 & 2515386 & $33336 \mathrm{E}$ \\
\hline OM01-14 & Sheeted Dike & 649144 & 2515386 & $33336 \mathrm{E}$ \\
\hline OM01-15 & Sheeted Dike & 649004 & 2515511 & $32741 \mathrm{E}$ \\
\hline OM01-16 & Sheeted Dike & 649004 & 2515511 & $32741 \mathrm{E}$ \\
\hline OM01-17 & Sheeted Dike & 649004 & 2515511 & $34043 \mathrm{E}$ \\
\hline OM01-18 & Sheeted Dike & 649004 & 2515511 & $34043 \mathrm{E}$ \\
\hline OM01-20 & Sheeted Dike & 649004 & 2515511 & $34043 \mathrm{E}$ \\
\hline OM01-21 & Sheeted Dike & 648978 & 2515585 & $034 \mathrm{E}$ \\
\hline OM01-22 & Sheeted Dike & 648978 & 2515585 & $034 \mathrm{E}$ \\
\hline OM01-23 & Sheeted Dike & 646697 & 2517840 & $2969 \mathrm{E}$ \\
\hline OM01-24 & Sheeted Dike & 646678 & 2518027 & $35385 \mathrm{E}$ \\
\hline OM01-26 & Sheeted Dike & 646702 & 2518229 & $19581 \mathrm{~W}$ \\
\hline OM01-27 & Sheeted Dike & 646702 & 2518229 & $19581 \mathrm{~W}$ \\
\hline OM01-28 & Sheeted Dike & 646702 & 2518229 & $290 \mathrm{E}$ \\
\hline OM01-29 & Sheeted Dike & 646749 & 2518271 & 20567 W \\
\hline OM01-30 & Sheeted Dike & 653678 & 2521694 & $34343 \mathrm{E}$ \\
\hline OM01-31 & Sheeted Dike & 653678 & 2521694 & $34343 \mathrm{E}$ \\
\hline OM01-33 & Sheeted Dike & 653500 & 2521311 & $34064 \mathrm{E}$ \\
\hline OM01-34 & Sheeted Dike & 653511 & 2521349 & \\
\hline OM01-35 & Sheeted Dike & 653835 & 2521407 & $073 \mathrm{E}$ \\
\hline OM01-36 & Sheeted Dike & 660201 & 2521737 & $33885 \mathrm{E}$ \\
\hline OM01-37 & Sheeted Dike & 660216 & 2521732 & 15776 W \\
\hline OM01-38 & Sheeted Dike & 660216 & 2521732 & 15776 W \\
\hline OM01-41 & Sheeted Dike & 661330 & 2522511 & $33070 \mathrm{E}$ \\
\hline OM01-42 & Sheeted Dike & 661180 & 2523511 & $371 \mathrm{E}$ \\
\hline OM01-46 & Sheeted Dike & 656264 & 2525231 & $33585 \mathrm{E}$ \\
\hline OM01-47 & Sheeted Dike & 656264 & 2525231 & $33585 \mathrm{E}$ \\
\hline OM01-48 & Sheeted Dike & 656264 & 2525231 & $33990 \mathrm{E}$ \\
\hline
\end{tabular}

This article is protected by copyright. All rights reserved. 
Table 2a. Whole Rock Compositions

Gabbros

Sample ID

$\operatorname{DMTZ}(\mathrm{m})$

Lithology

OM97-67a

OM97-63

OM97-70

OM97-45

OM97-52

OM97-59a

OM97-75

135

162

525

640

719

(wt\%)

$\mathrm{SiO}_{2}$

49.24

48.67

48.75

48.28

0.21

0.19

19.65

18.72

LG

LG

LG

$\mathrm{TiO}_{2}$

$\mathrm{Al}_{2} \mathrm{O}_{3}$

18.73

14.02

9.02

10.74

0.07

0.08

3.78

4.23

17.41

16.56

1.08

1.16

0.01

0.02

0.01

0.01

48.71

47.77

47.96

$\mathrm{K}_{2} \mathrm{O}$

0.00

0.01

0.22

0.24

0.23

$\mathrm{P}_{2} \mathrm{O}_{5}$

0.01

0.01

100.00

100.00

Mg\#

81.4

86.0

80.9

81.9

18.80

17.14

17.13

9.55

11.38

11.16

0.10

0.10

0.11

5.54

5.19

6.10

15.39

17.38

16.18

1.66

0.79

1.10

0.01

0.01

0.01

0.02

0.01

0.01

100.00

100.00

100.00

75.5

79.6

76.5

(ppm)

$\begin{array}{lccccccc}\mathrm{Sc} & 49.0 & 52.8 & 46.0 & 41.3 & 40.0 & 45.0 & 45.0 \\ \mathrm{~V} & 129 & 131 & 116 & 116 & 115 & 141 & 119 \\ \mathrm{Cr} & 906 & 1027 & 442 & 509 & 278 & 266 & 96 \\ \mathrm{Ni} & 166 & 339 & 127 & 162 & 89 & 138 & 102 \\ \mathrm{Cu} & 98 & 138 & 53 & 141 & 98 & 99 & 110 \\ \mathrm{Zn} & 14 & 12 & 10 & 14 & 14 & 17 & 22 \\ \mathrm{Ga} & 12 & 9 & 10 & 10 & 14 & 13 & 12 \\ \mathrm{Ti} & 1501 & 1364 & 1563 & 1385 & 1600 & 1775 & 1714 \\ \mathrm{Rb} & 0.06 & 0.05 & 0.06 & 0.05 & 0.06 & 0.05 & 0.04 \\ \mathrm{Sr} & 128.6 & 92.5 & 144.8 & 135.5 & 155.1 & 131.8 & 141.3 \\ \mathrm{Y} & 5.0 & 4.3 & 5.0 & 5.3 & 6.0 & 5.0 & 6.0 \\ \mathrm{Zr} & 3.3 & 2.4 & 4.9 & 2.4 & 4.5 & 3.2 & 5.8 \\ \mathrm{Nb} & 0.02 & 0.02 & 0.02 & 0.02 & 0.02 & 0.02 & 0.02 \\ \mathrm{Ba} & 2.8 & 1.9 & 7.4 & 3.0 & 3.8 & 2.1 & 3.0 \\ \mathrm{La} & 0.18 & 0.16 & 0.23 & 0.19 & 0.19 & 0.15 & 0.23 \\ \mathrm{Ce} & 0.58 & 0.40 & 0.56 & 0.54 & 0.60 & 0.57 & 0.75 \\ \mathrm{Pr} & 0.12 & 0.09 & 0.12 & 0.12 & 0.13 & 0.13 & 0.16 \\ \mathrm{Nd} & 0.86 & 0.69 & 0.83 & 0.80 & 0.92 & 0.92 & 1.11 \\ \mathrm{Sm} & 0.40 & 0.33 & 0.38 & 0.37 & 0.44 & 0.43 & 0.49 \\ \mathrm{Eu} & 0.27 & 0.18 & 0.23 & 0.25 & 0.30 & 0.25 & 0.31\end{array}$

This article is protected by copyright. All rights reserved. 


$\begin{array}{lccccccc}\mathrm{Gd} & 0.64 & 0.59 & 0.63 & 0.62 & 0.73 & 0.73 & 0.82 \\ \mathrm{~Tb} & 0.12 & 0.11 & 0.12 & 0.12 & 0.14 & 0.13 & 0.15 \\ \mathrm{Dy} & 0.89 & 0.83 & 0.86 & 0.86 & 1.04 & 1.00 & 1.11 \\ \mathrm{Ho} & 0.18 & 0.17 & 0.17 & 0.17 & 0.21 & 0.20 & 0.22 \\ \mathrm{Er} & 0.50 & 0.46 & 0.49 & 0.48 & 0.58 & 0.54 & 0.62 \\ \mathrm{Tm} & 0.07 & 0.06 & 0.07 & 0.07 & 0.08 & 0.07 & 0.09 \\ \mathrm{Yb} & 0.41 & 0.38 & 0.41 & 0.41 & 0.50 & 0.45 & 0.52 \\ \mathrm{Lu} & 0.06 & 0.06 & 0.06 & 0.06 & 0.08 & 0.07 & 0.08 \\ \mathrm{Hf} & 0.16 & 0.13 & 0.19 & 0.13 & 0.20 & 0.17 & 0.25 \\ \mathrm{~Pb} & 0.44 & \mathrm{n.d} & \mathrm{n.d} & 0.40 & 0.36 & 5.97 & 0.45 \\ \mathrm{Th} & 0.002 & 0.001 & 0.002 & 0.001 & 0.002 & 0.001 & 0.002 \\ \mathrm{U} & 0.002 & \mathrm{n.d} & 0.002 & \mathrm{n.d} & 0.002 & \mathrm{n} . \mathrm{d} . & \mathrm{n} . \mathrm{d} . \\ \mathrm{E}(\mathrm{Zr}) & & & & & & & \end{array}$

*LG = lower gabbro; UG = upper gabbro

** $\mathrm{E}=$ enrichment factor, calculated as described in text

n.d. $=$ not detected

This article is protected by copyright. All rights reserved. 


\begin{tabular}{|c|c|c|c|c|c|c|c|}
\hline OM99-40 & OM99-43 & OM99-44 & OM99-47 & OM99-49 & OM99-51 & OM99-53 & OM97-84 \\
\hline 961 & 961 & 1253 & 1392 & 1392 & 1535 & 1535 & 1663 \\
\hline LG & LG & LG & LG & LG & LG & LG & LG \\
\hline 47.04 & 47.64 & 46.78 & 47.37 & 48.06 & 47.87 & 48.74 & 48.58 \\
\hline 0.15 & 0.24 & 0.20 & 0.19 & 0.22 & 0.20 & 0.24 & 0.12 \\
\hline 18.83 & 16.03 & 16.55 & 15.19 & 13.24 & 14.50 & 13.12 & 26.50 \\
\hline 11.03 & 11.81 & 12.66 & 14.74 & 15.63 & 14.41 & 14.23 & 4.04 \\
\hline 0.10 & 0.12 & 0.12 & 0.11 & 0.12 & 0.09 & 0.09 & 0.04 \\
\hline 5.76 & 6.47 & 6.03 & 5.75 & 5.94 & 4.16 & 4.18 & 2.14 \\
\hline 15.01 & 15.41 & 15.72 & 15.17 & 15.71 & 17.28 & 18.16 & 16.48 \\
\hline 1.15 & 1.19 & 0.89 & 0.88 & 0.80 & 0.55 & 0.58 & 2.06 \\
\hline 0.01 & 0.00 & 0.00 & 0.00 & 0.00 & 0.01 & 0.00 & 0.03 \\
\hline 0.01 & 0.01 & 0.01 & 0.01 & 0.01 & 0.01 & 0.01 & 0.01 \\
\hline 99.08 & 98.93 & 98.96 & 99.42 & 99.72 & 99.07 & 99.36 & 100.00 \\
\hline 77.3 & 76.5 & 78.9 & 82.0 & 82.4 & 86.0 & 85.8 & 77.1 \\
\hline 33.6 & 48.9 & 46.4 & 46.5 & 55.0 & 56.0 & 65.4 & 32.0 \\
\hline 91 & 155 & 125 & 121 & 144 & 131 & 157 & 66 \\
\hline 569 & 199 & 246 & 313 & 522 & 831 & 876 & 158 \\
\hline 179 & 119 & 143 & 160 & 169 & 311 & 273 & 47 \\
\hline 117 & 19 & 200 & 30 & 39 & 189 & 228 & 15 \\
\hline 26 & 26 & 29 & 27 & 30 & 18 & 17 & 0 \\
\hline 11 & 10 & 9 & 10 & 8 & 9 & 7 & 15 \\
\hline 916 & 1417 & 1225 & 1133 & 1344 & 1170 & 1429 & 915 \\
\hline 0.08 & 0.06 & 0.09 & 0.05 & 0.06 & 0.10 & 0.06 & 0.12 \\
\hline 150.2 & 177.6 & 128.7 & 104.5 & 92.5 & 79.7 & 77.2 & 235.3 \\
\hline 3.8 & 5.6 & 5.4 & 5.1 & 6.3 & 4.7 & 5.8 & 2.0 \\
\hline 2.3 & 2.9 & 2.8 & 2.8 & 3.5 & 3.2 & 3.7 & 2.1 \\
\hline 0.03 & 0.02 & 0.01 & 0.02 & 0.03 & 0.04 & 0.03 & 0.02 \\
\hline 2.8 & 2.4 & 2.3 & 2.3 & 2.2 & 2.3 & 1.8 & 4.4 \\
\hline 0.15 & 0.17 & 0.18 & 0.16 & 0.17 & 0.15 & 0.15 & 0.20 \\
\hline 0.47 & 0.52 & 0.57 & 0.49 & 0.56 & 0.48 & 0.54 & 0.53 \\
\hline 0.10 & 0.12 & 0.13 & 0.11 & 0.13 & 0.10 & 0.13 & 0.10 \\
\hline 0.62 & 0.82 & 0.87 & 0.77 & 0.92 & 0.73 & 0.85 & 0.61 \\
\hline 0.31 & 0.44 & 0.45 & 0.41 & 0.50 & 0.37 & 0.46 & 0.24 \\
\hline 0.23 & 0.24 & 0.28 & 0.24 & 0.26 & 0.19 & 0.22 & 0.24 \\
\hline
\end{tabular}

This article is protected by copyright. All rights reserved. 


$\begin{array}{llllllll}0.55 & 0.74 & 0.72 & 0.71 & 0.80 & 0.61 & 0.74 & 0.38 \\ 0.10 & 0.14 & 0.14 & 0.13 & 0.15 & 0.12 & 0.15 & 0.07 \\ 0.65 & 0.96 & 0.91 & 0.86 & 1.06 & 0.80 & 0.95 & \\ 0.14 & 0.20 & 0.20 & 0.18 & 0.22 & 0.16 & 0.20 & 0.10 \\ 0.39 & 0.55 & 0.53 & 0.50 & 0.63 & 0.45 & 0.56 & 0.26 \\ 0.05 & 0.08 & 0.07 & 0.07 & 0.09 & 0.06 & 0.08 & 0.04 \\ 0.33 & 0.47 & 0.46 & 0.45 & 0.55 & 0.38 & 0.49 & 0.22 \\ 0.05 & 0.08 & 0.07 & 0.07 & 0.08 & 0.06 & 0.07 & 0.03 \\ 0.11 & 0.16 & 0.15 & 0.13 & 0.17 & 0.15 & 0.18 & 0.07 \\ 0.06 & 0.03 & 0.09 & 0.04 & 0.04 & 0.05 & 0.23 & 1.74 \\ 0.005 & 0.002 & 0.006 & 0.003 & 0.003 & 0.004 & 0.003 & 0.002 \\ 0.001 & 0.001 & 0.001 & 0.001 & 0.001 & 0.003 & 0.001 & \text { n.d. } \\ 5.7 & & & & & & & \\ & 7.4 & 7.0 & 7.0 & 8.8 & 8.1 & 9.2 & 5.2\end{array}$

This article is protected by copyright. All rights reserved. 


\begin{tabular}{|c|c|c|c|c|c|c|c|}
\hline OM97-89 & OM97-94a & OM97-200 & OM97-99 & OM97-97a & OM97-95 & OM97-102a & OM97-104 \\
\hline 1793 & 2011 & 2181 & 2193 & 2257 & 2303 & 2369 & 2999 \\
\hline LG & LG & LG & LG & LG & LG & LG & LG \\
\hline 47.78 & 47.91 & 47.35 & 47.93 & 48.21 & 47.81 & 47.59 & 47.73 \\
\hline 0.13 & 0.14 & 0.20 & 0.28 & 0.19 & 0.18 & 0.22 & 0.19 \\
\hline 19.74 & 21.34 & 16.38 & 16.47 & 19.35 & 17.68 & 18.35 & 18.28 \\
\hline 10.76 & 9.17 & 14.81 & 11.17 & 9.89 & 12.15 & 11.37 & 11.19 \\
\hline 0.09 & 0.07 & 0.11 & 0.11 & 0.09 & 0.09 & 0.10 & 0.10 \\
\hline 4.79 & 4.13 & 5.46 & 6.04 & 4.53 & 5.23 & 5.55 & 5.43 \\
\hline 15.56 & 15.90 & 14.78 & 17.09 & 16.57 & 15.88 & 15.76 & 16.04 \\
\hline 1.09 & 1.31 & 0.86 & 0.87 & 1.15 & 0.94 & 1.01 & 1.01 \\
\hline 0.05 & 0.02 & 0.02 & 0.02 & 0.01 & 0.01 & 0.03 & 0.01 \\
\hline 0.02 & 0.02 & 0.02 & 0.02 & 0.02 & 0.01 & 0.02 & 0.02 \\
\hline 100.00 & 100.00 & 100.00 & 100.00 & 100.00 & 100.00 & 100.00 & 100.00 \\
\hline 80.0 & 79.8 & 82.9 & 76.7 & 79.6 & 80.6 & 78.5 & 78.6 \\
\hline 39.0 & 41.0 & 42.0 & 46.0 & 43.0 & 45.0 & 35.0 & 40.0 \\
\hline 73 & 77 & 90 & 133 & 102 & 102 & 106 & 102 \\
\hline 508 & 332 & 201 & 174 & 399 & 435 & 585 & 618 \\
\hline 203 & 185 & 169 & 135 & 107 & 140 & 184 & 197 \\
\hline 80 & 100 & 29 & 164 & 38 & 137 & 137 & 125 \\
\hline 20 & 14 & 30 & 22 & 20 & 24 & 23 & 19 \\
\hline 9 & 14 & 12 & 11 & 14 & 13 & 13 & 14 \\
\hline 854 & 1041 & 1282 & 1878 & 1217 & 1182 & 1366 & 1281 \\
\hline 0.17 & 0.09 & 0.13 & 0.10 & 0.14 & 0.05 & 0.14 & 0.07 \\
\hline 137.6 & 171.4 & 103.9 & 147.0 & 141.2 & 119.8 & 128.6 & 133.2 \\
\hline 3.0 & 4.0 & 4.0 & 6.0 & 4.0 & 4.0 & 5.0 & 4.0 \\
\hline 2.0 & 2.5 & 3.6 & 5.7 & 4.0 & 2.8 & 3.8 & 3.2 \\
\hline 0.04 & 0.03 & 0.04 & 0.04 & 0.07 & 0.03 & 0.03 & 0.02 \\
\hline 3.7 & 3.6 & 3.1 & 4.0 & 4.2 & 2.6 & 3.8 & 3.5 \\
\hline 0.21 & 0.19 & 0.29 & 0.32 & 0.27 & 0.17 & 0.24 & 0.23 \\
\hline 0.58 & 0.54 & 0.73 & 1.06 & 0.84 & 0.52 & 0.75 & 0.67 \\
\hline 0.11 & 0.10 & 0.14 & 0.21 & 0.15 & 0.11 & 0.14 & 0.13 \\
\hline 0.67 & 0.66 & 0.90 & 1.42 & 0.96 & 0.74 & 0.97 & 0.87 \\
\hline 0.27 & 0.27 & 0.39 & 0.61 & 0.40 & 0.33 & 0.41 & 0.38 \\
\hline 0.25 & 0.21 & 0.25 & 0.34 & 0.29 & 0.24 & 0.28 & 0.27 \\
\hline
\end{tabular}

This article is protected by copyright. All rights reserved. 


\begin{tabular}{|c|c|c|c|c|c|c|c|}
\hline 0.45 & 0.44 & 0.66 & 1.02 & 0.67 & 0.57 & 0.69 & 0.65 \\
\hline 0.08 & 0.08 & 0.12 & 0.18 & 0.12 & 0.10 & 0.13 & 0.12 \\
\hline 0.62 & 0.59 & 0.91 & 1.35 & 0.90 & 0.78 & 0.94 & 0.88 \\
\hline 0.12 & 0.12 & 0.18 & 0.27 & 0.18 & 0.16 & 0.19 & 0.17 \\
\hline 0.34 & 0.33 & 0.50 & 0.73 & 0.49 & 0.41 & 0.51 & 0.46 \\
\hline 0.05 & 0.05 & 0.07 & 0.10 & 0.07 & 0.06 & 0.07 & 0.06 \\
\hline 0.28 & 0.28 & 0.42 & 0.61 & 0.41 & 0.35 & 0.42 & 0.39 \\
\hline 0.04 & 0.04 & 0.07 & 0.09 & 0.06 & 0.05 & 0.06 & 0.06 \\
\hline 0.09 & 0.10 & 0.15 & 0.23 & 0.16 & 0.13 & 0.18 & 0.15 \\
\hline 0.80 & 0.32 & 4.87 & 3.90 & 14.28 & 10.76 & 0.91 & n.d. \\
\hline 0.001 & 0.003 & 0.004 & 0.003 & 0.005 & 0.002 & 0.004 & 0.002 \\
\hline n.d. & 0.002 & n.d. & n.d. & 0.002 & n.d. & n.d. & n.d. \\
\hline 5.0 & 6.1 & 9.0 & 14.2 & 10.1 & 7.0 & 9.6 & 8.1 \\
\hline
\end{tabular}

This article is protected by copyright. All rights reserved. 


\begin{tabular}{|c|c|c|c|c|c|c|c|}
\hline OM97-106 & OM97-204 & OM97-111 & OM97-110 & OM97-108 & OM97-112 & OM97-113 & OM97-114 \\
\hline 3260 & 3573 & 3594 & 3627 & 3632 & 3691 & 3989 & 4367 \\
\hline LG & LG & LG & LG & LG & LG & UG & UG \\
\hline 49.69 & 47.95 & 48.32 & 48.49 & 46.29 & 48.92 & 49.72 & 49.29 \\
\hline 0.37 & 0.21 & 0.23 & 0.23 & 0.12 & 0.27 & 0.47 & 0.83 \\
\hline 16.24 & 18.79 & 17.01 & 16.91 & 18.71 & 15.98 & 16.78 & 21.29 \\
\hline 10.24 & 11.25 & 11.24 & 12.04 & 14.24 & 11.79 & 10.23 & 5.71 \\
\hline 0.12 & 0.08 & 0.11 & 0.10 & 0.11 & 0.09 & 0.12 & 0.09 \\
\hline 5.59 & 4.12 & 5.49 & 4.95 & 6.26 & 4.41 & 6.51 & 6.47 \\
\hline 16.13 & 16.43 & 16.55 & 16.08 & 13.08 & 17.54 & 14.30 & 13.49 \\
\hline 1.59 & 1.10 & 1.01 & 1.15 & 1.16 & 0.97 & 1.75 & 2.67 \\
\hline 0.01 & 0.05 & 0.02 & 0.02 & 0.02 & 0.02 & 0.07 & 0.11 \\
\hline 0.02 & 0.02 & 0.02 & 0.02 & 0.02 & 0.02 & 0.04 & 0.04 \\
\hline 100.00 & 100.00 & 100.00 & 100.00 & 100.00 & 100.00 & 100.00 & 100.00 \\
\hline 76.5 & 82.9 & 78.5 & 81.3 & 80.2 & 82.7 & 73.7 & 61.1 \\
\hline 51.0 & 42.0 & 44.3 & 47.0 & 27.0 & 52.0 & 41.0 & 34.0 \\
\hline 153 & 98 & 126 & 116 & 59 & 125 & 135 & 294 \\
\hline 517 & 487 & 438 & 687 & 479 & 1062 & 424 & 117 \\
\hline 162 & 158 & 158 & 203 & 285 & 205 & 138 & 55 \\
\hline 89 & 25 & 136 & 92 & 109 & 97 & 79 & 122 \\
\hline 26 & 18 & 21 & 29 & 28 & 20 & 28 & 18 \\
\hline 13 & 12 & 10 & 12 & 11 & 11 & 12 & 15 \\
\hline 2112 & 1351 & 1516 & 1562 & 787 & 1772 & 2478 & 4441 \\
\hline 0.06 & 0.49 & 0.08 & 0.15 & 0.10 & 0.13 & 0.33 & 0.26 \\
\hline 138.2 & 129.0 & 135.8 & 123.0 & 146.2 & 128.0 & 139.0 & 185.8 \\
\hline 9.0 & 6.0 & 6.5 & 7.0 & 2.0 & 8.0 & 12.0 & 12.0 \\
\hline 7.0 & 5.6 & 4.7 & 6.6 & 2.9 & 7.7 & 32.1 & 13.8 \\
\hline 0.04 & 0.07 & 0.04 & 0.11 & 0.05 & 0.13 & 0.60 & 0.60 \\
\hline 3.4 & 3.8 & 2.9 & 4.2 & 3.3 & 4.3 & 12.4 & 12.5 \\
\hline 0.35 & 0.27 & 0.23 & 0.33 & 0.21 & 0.37 & 1.21 & 0.95 \\
\hline 1.13 & 0.82 & 0.77 & 1.05 & 0.58 & 1.21 & 3.57 & 2.94 \\
\hline 0.24 & 0.16 & 0.16 & 0.21 & 0.10 & 0.22 & 0.59 & 0.49 \\
\hline 1.66 & 1.00 & 1.08 & 1.25 & 0.60 & 1.46 & 3.35 & 2.73 \\
\hline 0.77 & 0.42 & 0.49 & 0.53 & 0.23 & 0.60 & 1.17 & 0.95 \\
\hline 0.44 & 0.27 & 0.31 & 0.34 & 0.22 & 0.32 & 0.56 & 0.53 \\
\hline
\end{tabular}

This article is protected by copyright. All rights reserved. 


$\begin{array}{cccccccc}1.31 & 0.70 & 0.84 & 0.87 & 0.37 & 0.96 & 1.72 & 1.41 \\ 0.24 & 0.13 & 0.15 & 0.16 & 0.06 & 0.17 & 0.31 & 0.25 \\ 1.75 & 0.94 & 1.14 & 1.17 & 0.48 & 1.29 & 2.21 & 1.86 \\ 0.35 & 0.19 & 0.22 & 0.23 & 0.09 & 0.25 & 0.44 & 0.38 \\ 0.92 & 0.52 & 0.63 & 0.63 & 0.26 & 0.72 & 1.27 & 1.07 \\ 0.13 & 0.07 & 0.08 & 0.09 & 0.04 & 0.10 & 0.18 & 0.15 \\ 0.77 & 0.45 & 0.51 & 0.55 & 0.22 & 0.60 & 1.13 & 0.98 \\ 0.12 & 0.07 & 0.08 & 0.09 & 0.04 & 0.09 & 0.18 & 0.16 \\ 0.34 & 0.20 & 0.20 & 0.22 & 0.10 & 0.27 & 0.85 & 0.45 \\ 0.31 & \text { n.d. } & 0.30 & 1.42 & 0.56 & 0.47 & 2.76 & 0.46 \\ 0.002 & 0.009 & 0.002 & 0.009 & 0.004 & 0.009 & 0.075 & 0.033 \\ \text { n.d. } & 0.004 & 0.002 & 0.004 & \text { n.d. } & 0.004 & 0.029 & 0.014 \\ & & & & & & & \end{array}$




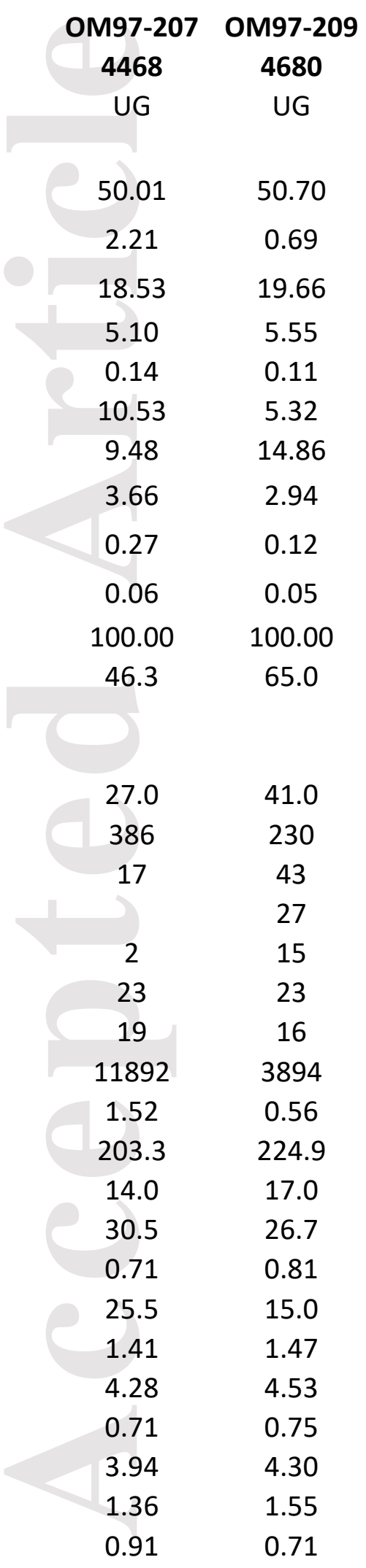

This article is protected by copyright. All rights reserved. 


$\begin{array}{ll}1.95 & 2.29 \\ 0.34 & 0.41 \\ 2.50 & 3.01 \\ 0.50 & 0.59 \\ 1.45 & 1.69 \\ 0.21 & 0.24 \\ 1.31 & 1.49 \\ 0.21 & 0.23 \\ 0.84 & 0.81 \\ 0.74 & 0.43 \\ 0.070 & 0.061 \\ 0.031 & 0.025 \\ 76.3 & 66.6\end{array}$

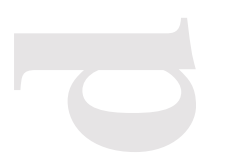

This article is protected by copyright. All rights reserved. 
Table 2b. Whole Rock Compositions

\section{Sheeted Dikes}

\begin{tabular}{|c|c|c|c|c|c|c|c|c|c|}
\hline Sample ID & OM01-0S & M01-1 & M01-1 & M01-1 & M01-13 & M01-13 & M01-1 & M01-1 & M01-16 \\
\hline DMTZ(m) & 5200 & 5225 & 5250 & 5275 & 5300 & 5325 & 5350 & 5375 & 5400 \\
\hline $\begin{array}{l}\text { Lithology } \\
\text { (wt\%) }\end{array}$ & SD & SD & SD & SD & SD & SD & SD & SD & SD \\
\hline $\mathrm{SiO}_{2}$ & 52.64 & 54.60 & 53.08 & 53.61 & 51.96 & 53.29 & 50.37 & 53.91 & 56.11 \\
\hline $\mathrm{TiO}_{2}$ & 0.95 & 1.34 & 1.16 & 1.35 & 1.03 & 1.09 & 0.81 & 1.41 & 1.12 \\
\hline $\mathrm{Al}_{2} \mathrm{O}_{3}$ & 15.98 & 15.68 & 15.86 & 15.68 & 16.43 & 16.04 & 16.36 & 16.04 & 15.88 \\
\hline $\mathrm{MgO}$ & 6.51 & 5.29 & 5.25 & 5.11 & 6.34 & 5.56 & 6.97 & 4.90 & 4.99 \\
\hline $\mathrm{MnO}$ & 0.17 & 0.15 & 0.14 & 0.15 & 0.12 & 0.11 & 0.11 & 0.18 & 0.16 \\
\hline $\mathrm{FeO}$ & 8.74 & 8.54 & 9.84 & 9.26 & 9.51 & 9.30 & 8.17 & 10.31 & 8.53 \\
\hline $\mathrm{CaO}$ & 8.22 & 6.96 & 8.00 & 6.97 & 7.68 & 7.58 & 10.79 & 5.56 & 5.18 \\
\hline $\mathrm{Na}_{2} \mathrm{O}$ & 4.44 & 5.67 & 4.56 & 5.36 & 4.78 & 5.06 & 3.53 & 5.56 & 6.06 \\
\hline $\mathrm{K}_{2} \mathrm{O}$ & 0.34 & 0.50 & 0.11 & 0.38 & 0.38 & 0.45 & 0.05 & 0.54 & 0.33 \\
\hline $\mathrm{P}_{2} \mathrm{O}_{5}$ & 0.09 & 0.13 & 0.10 & 0.13 & 0.10 & 0.10 & 0.08 & 0.14 & 0.10 \\
\hline Total & 98.08 & 98.86 & 98.10 & 97.99 & 98.33 & 98.59 & 97.24 & 98.55 & 98.46 \\
\hline Mg\# & 57.04 & 52.48 & 48.75 & 49.59 & 54.30 & 51.59 & 60.33 & 45.86 & 51.05 \\
\hline (ppm) & & & & & & & & & \\
\hline Sc & 31.9 & 31.6 & 33.2 & 34.5 & 35.2 & 35.5 & 36.3 & 27.9 & 35.1 \\
\hline V & 228 & 294 & 299 & 301 & 241 & 274 & 207 & 285 & 280 \\
\hline $\mathrm{Cr}$ & 104 & 56 & 36 & 55 & 33 & 29 & 105 & 22 & 27 \\
\hline $\mathrm{Ni}$ & 46 & 23 & 25 & 22 & 31 & 26 & 56 & 14 & 16 \\
\hline $\mathrm{Cu}$ & 8 & 6 & 17 & 9 & 102 & 23 & 14 & 5 & 5 \\
\hline $\mathrm{Zn}$ & 19 & 12 & 18 & 15 & 14 & 12 & 14 & 18 & 20 \\
\hline Ga & 14.7 & 12.0 & 17.2 & 13.9 & 15.3 & 14.2 & 14.1 & 23.4 & 17.7 \\
\hline $\mathrm{Rb}$ & 1.2 & 1.6 & 0.2 & 1.3 & 1.7 & 1.5 & -0.1 & 1.8 & 1.1 \\
\hline $\mathrm{Sr}$ & 335 & 349 & 93 & 337 & 354 & 291 & 174 & 204 & 186 \\
\hline Y & 20.3 & 30.9 & 24.9 & 27.8 & 23.2 & 24.8 & 19.8 & 34.2 & 24.0 \\
\hline $\mathrm{Zr}$ & 164.0 & 83.1 & 68.6 & 87.2 & 64.6 & 70.3 & 69.4 & 96.0 & 67.5 \\
\hline $\mathrm{Nb}$ & 1.11 & 2.06 & 1.33 & 1.95 & 1.22 & 1.32 & 0.94 & 2.10 & 1.31 \\
\hline $\mathrm{Ba}$ & 24 & 49 & 3 & 42 & 73 & 71 & 3 & 31 & 20 \\
\hline La & 1.97 & 2.87 & 3.35 & 2.83 & 2.95 & 3.55 & 2.42 & 3.77 & 2.98 \\
\hline $\mathrm{Ce}$ & 5.87 & 9.28 & 9.22 & 8.44 & 8.35 & 9.61 & 6.33 & 10.48 & 8.35 \\
\hline $\mathrm{Pr}$ & 1.03 & 1.64 & 1.53 & 1.48 & 1.38 & 1.55 & 1.15 & 1.92 & 1.40 \\
\hline $\mathrm{Nd}$ & 5.54 & 8.73 & 7.71 & 7.84 & 7.09 & 7.84 & 5.96 & 10.05 & 7.22 \\
\hline Sm & 2.02 & 2.93 & 2.47 & 2.68 & 2.31 & 2.50 & 1.98 & 3.37 & 2.41 \\
\hline $\mathrm{Eu}$ & 0.67 & 1.08 & 0.88 & 1.06 & 0.91 & 0.95 & 0.75 & 1.11 & 0.93 \\
\hline $\mathrm{Gd}$ & 2.79 & 3.78 & 3.22 & 3.58 & 3.07 & 3.25 & 2.53 & 4.27 & 3.17 \\
\hline
\end{tabular}




\begin{tabular}{|c|c|c|c|c|c|c|c|c|c|}
\hline $\mathrm{Tb}$ & 0.51 & 0.69 & 0.58 & 0.64 & 0.54 & 0.57 & 0.48 & 0.81 & 0.55 \\
\hline Dy & 3.27 & 4.67 & 3.87 & 4.35 & 3.60 & 3.80 & 3.08 & 5.21 & 3.71 \\
\hline $\mathrm{Ho}$ & 0.71 & 1.01 & 0.84 & 0.93 & 0.77 & 0.82 & 0.66 & 1.13 & 0.80 \\
\hline $\mathrm{Er}$ & 2.05 & 2.88 & 2.39 & 2.66 & 2.20 & 2.31 & 1.91 & 3.23 & 2.30 \\
\hline $\mathrm{Tm}$ & 0.31 & 0.44 & 0.37 & 0.41 & 0.34 & 0.35 & 0.30 & 0.50 & 0.35 \\
\hline $\mathrm{Yb}$ & 2.05 & 2.78 & 2.36 & 2.61 & 2.18 & 2.28 & 1.89 & 3.15 & 2.26 \\
\hline Lu & 0.33 & 0.43 & 0.37 & 0.40 & 0.34 & 0.36 & 0.30 & 0.49 & 0.36 \\
\hline $\mathrm{Hf}$ & 3.84 & 2.36 & 1.97 & 2.40 & 1.79 & 1.98 & 1.85 & 2.59 & 1.97 \\
\hline $\mathrm{Ta}$ & 0.098 & 0.158 & 0.142 & 0.152 & 0.105 & 0.107 & 0.078 & 0.163 & 0.108 \\
\hline Th & 0.185 & 0.204 & 0.142 & 0.194 & 0.239 & 0.165 & 0.130 & 0.236 & 0.184 \\
\hline$U$ & 0.11 & 0.08 & 0.09 & 0.11 & 0.11 & 0.10 & 0.04 & 1.60 & 0.11 \\
\hline \multicolumn{10}{|c|}{ SD $=$ sheeted dike } \\
\hline \multicolumn{10}{|c|}{$\mathrm{RSD}=$ relative standard deviation } \\
\hline \multicolumn{10}{|c|}{ d.l. = detection limit } \\
\hline \multicolumn{10}{|c|}{ rec. =recommended } \\
\hline \multicolumn{10}{|c|}{ meas. $=$ measured } \\
\hline$D M$ & $t+i$ & 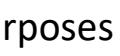 & & & & & & & \\
\hline
\end{tabular}

This article is protected by copyright. All rights reserved. 


\section{OM01-17 OM01-18 OM01-20 OM01-21 OM01-22 OM01-23 OM01-24 OM01-26 OM01-27 OM01-28 $\begin{array}{llllllllll}5425 & 5450 & 5475 & 5500 & 5525 & 5550 & 5575 & 5600 & 5625 & 5650\end{array}$

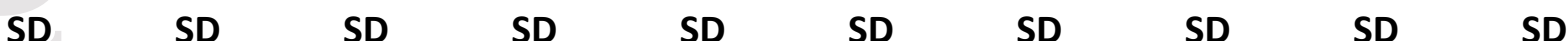

$\begin{array}{cccccccccc}54.20 & 52.29 & 51.67 & 54.68 & 51.98 & 51.14 & 52.52 & 51.93 & 52.73 & 54.07 \\ 1.13 & 1.13 & 1.22 & 1.31 & 1.06 & 1.27 & 1.05 & 1.39 & 1.40 & 1.40 \\ 16.23 & 16.08 & 16.76 & 15.28 & 16.41 & 16.34 & 15.74 & 16.97 & 16.12 & 16.30 \\ 6.16 & 5.81 & 6.16 & 5.01 & 7.07 & 3.18 & 5.55 & 4.54 & 4.82 & 4.51 \\ 0.17 & 0.17 & 0.18 & 0.15 & 0.16 & 0.06 & 0.07 & 0.13 & 0.14 & 0.14 \\ 9.57 & 9.96 & 10.93 & 10.27 & 9.16 & 10.68 & 9.93 & 11.33 & 11.14 & 10.79 \\ 4.91 & 6.95 & 5.25 & 5.31 & 7.11 & 11.54 & 8.68 & 5.92 & 6.30 & 4.60 \\ 5.93 & 5.55 & 5.36 & 5.80 & 4.43 & 4.47 & 3.83 & 5.77 & 5.46 & 6.32 \\ 0.26 & 0.15 & 0.24 & 0.35 & 0.55 & 0.03 & 0.36 & 0.16 & 0.18 & 0.11 \\ 0.11 & 0.09 & 0.12 & 0.12 & 0.09 & 0.11 & 0.10 & 0.13 & 0.12 & 0.14 \\ 98.66 & 98.19 & 97.89 & 98.27 & 98.02 & 98.82 & 97.82 & 98.26 & 98.41 & 98.38 \\ 53.43 & 50.98 & 50.12 & 46.51 & 57.91 & 34.67 & 49.91 & 41.67 & 43.54 & 42.70\end{array}$

$\begin{array}{cccccccccc}31.3 & 30.0 & 29.8 & 35.1 & 38.1 & 24.7 & 33.0 & 29.5 & 31.4 & 25.3 \\ 234 & 261 & 267 & 325 & 241 & 307 & 255 & 305 & 320 & 292 \\ 18 & 19 & 20 & 33 & 154 & 20 & 25 & 42 & 55 & 18 \\ 21 & 21 & 22 & 17 & 62 & 4 & 19 & 18 & 16 & 10 \\ 3 & 2 & 4 & 4 & 4 & 2 & 5 & 3 & 5 & 8 \\ 25 & 20 & 21 & 17 & 15 & 7 & 11 & 18 & 22 & 26 \\ 16.0 & 16.1 & 18.9 & 15.8 & 18.4 & 31.1 & 16.2 & 19.8 & 20.0 & 17.8 \\ 0.8 & 0.3 & 0.9 & 0.8 & 1.8 & 0.1 & 1.0 & 0.7 & 0.7 & 0.5 \\ 208 & 100 & 140 & 110 & 285 & 64 & 147 & 108 & 114 & 172 \\ 25.0 & 23.3 & 26.6 & 28.9 & 25.5 & 28.9 & 25.3 & 33.5 & 31.4 & 34.6 \\ 68.8 & 69.0 & 69.6 & 71.1 & 58.4 & 83.0 & 65.2 & 91.0 & 81.9 & 93.0 \\ 1.57 & 1.27 & 1.67 & 1.58 & 1.34 & 1.56 & 1.28 & 1.71 & 1.64 & 1.88 \\ 15 & 0 & 17 & 18 & 24 & 2 & 16 & 21 & 11 & 17 \\ 3.01 & 2.93 & 3.35 & 3.11 & 2.24 & 3.19 & 2.62 & 3.57 & 3.40 & 3.48 \\ 8.76 & 8.21 & 9.59 & 9.18 & 6.76 & 9.39 & 8.00 & 10.46 & 9.87 & 10.30 \\ 1.48 & 1.39 & 1.59 & 1.58 & 1.19 & 1.61 & 1.36 & 1.83 & 1.72 & 1.84 \\ 7.56 & 7.09 & 8.15 & 8.37 & 6.46 & 8.49 & 7.25 & 9.62 & 9.07 & 9.73 \\ 2.48 & 2.32 & 2.65 & 2.82 & 2.29 & 2.79 & 2.43 & 3.20 & 3.05 & 3.25 \\ 0.86 & 0.91 & 0.91 & 1.00 & 0.91 & 1.01 & 0.84 & 1.06 & 1.14 & 1.09 \\ 3.22 & 3.03 & 3.48 & 3.74 & 3.17 & 3.69 & 3.13 & 4.12 & 3.88 & 4.19\end{array}$

This article is protected by copyright. All rights reserved. 


$\begin{array}{cccccccccc}0.58 & 0.53 & 0.61 & 0.67 & 0.57 & 0.65 & 0.58 & 0.75 & 0.71 & 0.77 \\ 3.87 & 3.57 & 4.11 & 4.55 & 3.91 & 4.36 & 3.95 & 5.06 & 4.81 & 5.18 \\ 0.85 & 0.77 & 0.89 & 0.99 & 0.85 & 0.95 & 0.86 & 1.10 & 1.04 & 1.14 \\ 2.43 & 2.20 & 2.52 & 2.83 & 2.42 & 2.72 & 2.47 & 3.17 & 2.99 & 3.26 \\ 0.37 & 0.34 & 0.39 & 0.44 & 0.38 & 0.42 & 0.39 & 0.50 & 0.46 & 0.51 \\ 2.44 & 2.15 & 2.52 & 2.84 & 2.42 & 2.75 & 2.47 & 3.19 & 2.96 & 3.27 \\ 0.38 & 0.33 & 0.39 & 0.44 & 0.38 & 0.43 & 0.38 & 0.49 & 0.46 & 0.52 \\ 2.11 & 1.88 & 2.18 & 2.26 & 1.91 & 2.16 & 1.85 & 2.41 & 2.36 & 2.42 \\ 0.130 & 0.105 & 0.128 & 0.124 & 0.103 & 0.122 & 0.104 & 0.134 & 0.132 & 0.153 \\ 0.237 & 0.172 & 0.237 & 0.200 & 0.168 & 0.243 & 0.190 & 0.252 & 0.227 & 0.276 \\ 0.14 & 0.08 & 0.15 & 0.21 & 0.11 & 0.26 & 0.13 & 0.18 & 0.16 & 0.20\end{array}$




\section{OM01-29 OM01-30 OM01-31 OM01-33 OM01-34 OM01-35 OM01-36 OM01-37 OM01-38 OM01-41 $\begin{array}{llllllllll}5675 & 5700 & 5725 & 5750 & 5775 & 5800 & 5825 & 5850 & 5875 & 5900\end{array}$

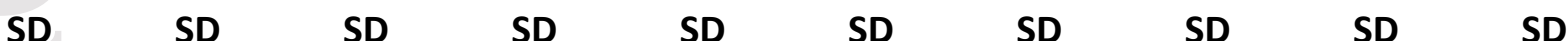

$\begin{array}{cccccccccc}54.85 & 53.91 & 51.46 & 52.15 & 52.82 & 49.80 & 58.04 & 61.08 & 61.55 & 55.60 \\ 1.60 & 1.73 & 1.72 & 1.84 & 1.66 & 2.08 & 1.40 & 1.21 & 1.26 & 1.71 \\ 16.82 & 15.21 & 14.98 & 15.10 & 15.38 & 14.30 & 14.97 & 14.03 & 14.28 & 15.13 \\ 3.66 & 4.18 & 4.57 & 4.93 & 4.48 & 4.39 & 2.70 & 2.08 & 2.41 & 4.16 \\ 0.12 & 0.09 & 0.12 & 0.10 & 0.09 & 0.28 & 0.28 & 0.13 & 0.12 & 0.18 \\ 7.22 & 11.80 & 13.31 & 12.35 & 12.79 & 20.80 & 10.94 & 10.74 & 9.92 & 11.54 \\ 7.69 & 6.27 & 6.69 & 6.81 & 5.33 & 2.10 & 5.16 & 3.92 & 3.08 & 5.31 \\ 5.35 & 5.72 & 5.11 & 5.16 & 5.97 & 3.63 & 3.21 & 3.42 & 5.43 & 3.70 \\ 0.08 & 0.26 & 0.13 & 0.23 & 0.23 & 0.06 & 0.53 & 0.73 & 0.25 & 0.76 \\ 0.17 & 0.15 & 0.13 & 0.15 & 0.13 & 0.14 & 0.19 & 0.21 & 0.20 & 0.20 \\ 97.56 & 99.31 & 98.22 & 98.82 & 98.89 & 97.58 & 97.42 & 97.54 & 98.49 & 98.29 \\ 47.47 & 38.71 & 37.97 & 41.58 & 38.44 & 27.34 & 30.55 & 25.66 & 30.22 & 39.12\end{array}$

$\begin{array}{cccccccccc}22.0 & 31.3 & 34.0 & 34.2 & 32.4 & 34.4 & 24.3 & 20.1 & 20.1 & 27.0 \\ 270 & 393 & 437 & 530 & 449 & 454 & 159 & 73 & & 277 \\ 11 & 26 & 28 & 35 & 31 & 23 & 8 & 0 & & 36 \\ 6 & 9 & 10 & 16 & 11 & 13 & 4 & 6 & & 22 \\ 3 & 5 & 16 & 11 & 9 & 14 & 39 & 5 & & 3 \\ 23 & 12 & 22 & 19 & 15 & 120 & 85 & 31 & & 18 \\ 17.0 & 17.2 & 19.5 & 15.9 & 18.0 & 19.7 & 18.7 & 14.7 & 15.1 & 19.0 \\ 0.3 & 1.0 & 0.0 & 1.2 & 0.6 & 0.6 & 2.1 & 3.4 & 1.0 & 4.0 \\ 115 & 220 & 90 & 167 & 148 & 50 & 303 & 169 & 141 & 262 \\ 36.8 & 33.5 & 31.5 & 38.7 & 36.7 & 34.6 & 42.9 & 45.5 & 42.2 & 42.6 \\ 108.5 & 90.3 & 84.6 & 96.0 & 91.0 & 89.3 & 122.6 & 133.0 & 128.3 & 134.0 \\ 2.72 & 2.44 & 2.21 & 2.36 & 2.28 & 2.27 & 2.45 & 2.74 & 2.89 & 3.62 \\ 7 & 18 & 8 & 10 & 26 & 5 & 35 & 41 & 29 & 49 \\ 3.77 & 5.16 & 3.71 & 4.73 & 4.17 & 4.14 & 5.06 & 5.32 & 5.25 & 5.70 \\ 10.99 & 13.31 & 10.51 & 14.85 & 14.20 & 11.67 & 14.72 & 15.98 & 14.74 & 16.33 \\ 1.81 & 1.97 & 1.67 & 2.41 & 2.47 & 1.95 & 2.50 & 2.57 & 2.45 & 2.71 \\ 9.55 & 9.90 & 8.71 & 12.07 & 12.80 & 10.16 & 12.88 & 13.15 & 12.74 & 13.71 \\ 3.31 & 3.23 & 2.98 & 3.85 & 3.97 & 3.32 & 4.17 & 4.27 & 4.40 & 4.30 \\ 1.21 & 1.30 & 1.08 & 1.61 & 1.56 & 1.29 & 1.41 & 1.37 & 1.47 & 1.45 \\ 4.50 & 4.15 & 3.95 & 4.96 & 5.05 & 4.40 & 5.30 & 5.48 & 5.79 & 5.34\end{array}$




$\begin{array}{cccccccccc}0.81 & 0.75 & 0.71 & 0.88 & 0.86 & 0.78 & 1.01 & 1.01 & 1.05 & 0.96 \\ 5.55 & 5.07 & 4.83 & 5.87 & 5.70 & 5.25 & 6.46 & 6.91 & 6.79 & 6.39 \\ 1.21 & 1.10 & 1.05 & 1.28 & 1.23 & 1.15 & 1.41 & 1.52 & 1.43 & 1.37 \\ 3.50 & 3.16 & 2.99 & 3.63 & 3.48 & 3.23 & 4.04 & 4.35 & 4.16 & 3.85 \\ 0.54 & 0.49 & 0.46 & 0.56 & 0.53 & 0.50 & 0.64 & 0.67 & 0.62 & 0.59 \\ 3.52 & 3.15 & 2.92 & 3.52 & 3.33 & 3.19 & 4.03 & 4.27 & 3.84 & 3.80 \\ 0.55 & 0.49 & 0.44 & 0.53 & 0.49 & 0.48 & 0.62 & 0.64 & 0.55 & 0.58 \\ 2.83 & 2.54 & 2.42 & 2.53 & 2.43 & 2.44 & 3.28 & 3.39 & 3.58 & 3.45 \\ 0.202 & 0.180 & 0.165 & 0.169 & 0.165 & 0.176 & 0.189 & 0.204 & 0.216 & 0.256 \\ 0.317 & 0.219 & 0.170 & 0.221 & 0.181 & 0.218 & 0.338 & 0.313 & 0.295 & 0.291 \\ 0.17 & 0.16 & 0.14 & 0.15 & 0.17 & 0.16 & 0.21 & 0.17 & 0.22 & 0.14\end{array}$




\begin{tabular}{|c|c|c|c|}
\hline \multicolumn{4}{|c|}{ OM01-42 OM01-46 OM01-47 OM01-4ع } \\
\hline 5925 & 5950 & 5975 & 6000 \\
\hline SD & SD & SD & SD \\
\hline 49.98 & 50.54 & 50.17 & 53.31 \\
\hline 1.64 & 0.92 & 0.89 & 0.95 \\
\hline 15.46 & 16.19 & 16.23 & 16.09 \\
\hline 4.83 & 8.40 & 8.80 & 7.10 \\
\hline 0.14 & 0.15 & 0.14 & 0.11 \\
\hline 13.71 & 8.83 & 8.91 & 8.72 \\
\hline 7.77 & 12.03 & 12.53 & 8.84 \\
\hline 2.49 & 2.30 & 1.93 & 4.12 \\
\hline 0.53 & 0.10 & 0.07 & 0.12 \\
\hline 0.11 & 0.07 & 0.06 & 0.09 \\
\hline 96.67 & 99.54 & 99.72 & 99.44 \\
\hline 38.58 & 62.91 & 63.78 & 59.21 \\
\hline
\end{tabular}

standards

BIR-1 BIR-1 BIR-1 JB-1a JB-1a

meas. RSD\% rec. meas. RSD\% 


$\begin{array}{ccccccccc}0.69 & 0.44 & 0.47 & 0.53 & 0.38 & 3.22 & 0.36 & 0.72 & 1.11 \\ 4.78 & 2.88 & 3.17 & 3.57 & 2.49 & 4.13 & 2.51 & 3.99 & 1.02 \\ 1.04 & 0.63 & 0.69 & 0.77 & 0.56 & 3.18 & 0.56 & 0.78 & 1.94 \\ 2.98 & 1.76 & 1.95 & 2.22 & 1.67 & 3.57 & 1.66 & 2.15 & 1.36 \\ 0.46 & 0.28 & 0.30 & 0.34 & 0.25 & 4.78 & 0.25 & 0.33 & 0.81 \\ 2.99 & 1.74 & 1.91 & 2.20 & 1.66 & 2.91 & 1.65 & 2.06 & 1.11 \\ 0.47 & 0.27 & 0.29 & 0.34 & 0.26 & 3.82 & 0.25 & 0.32 & 0.95 \\ 2.27 & 1.42 & 1.36 & 1.62 & 0.57 & 5.41 & 0.58 & 3.46 & 1.60 \\ 0.130 & 0.085 & 0.092 & 0.119 & 0.038 & 5.46 & 0.036 & 1.79 & 1.57 \\ 0.139 & 0.111 & 0.098 & 0.135 & 0.034 & 16.06 & 0.032 & 8.43 & 1.20 \\ 0.12 & 0.08 & 0.05 & 0.04 & 0.008 & 20.38 & 0.01 & 1.65 & 1.31\end{array}$

This article is protected by copyright. All rights reserved. 
JB-1a d.I.

rec.

\begin{tabular}{cc}
\hline 27.9 & 0.3 \\
212 & 0.07 \\
403 & 0.2 \\
140 & 0.3 \\
56 & 0.3 \\
82 & 0.4 \\
17.9 & 0.02 \\
40.1 & 0.03 \\
442 & 0.3 \\
24 & 0.02 \\
145 & 0.05 \\
27 & 0.09 \\
501 & 0.40 \\
37.8 & 0.01 \\
66 & 0.01 \\
7.3 & 0.003 \\
25.7 & 0.006 \\
5.07 & 0.005 \\
1.47 & 0.002 \\
4.61 & 0.03
\end{tabular}

This article is protected by copyright. All rights reserved. 
$0.69 \quad 0.01$

$4.09 \quad 0.003$

$0.68 \quad 0.001$

$2.18 \quad 0.003$

$0.32 \quad 0.001$

2.10 .003

$0.32 \quad 0.004$

$3.45 \quad 0.002$

$1.96 \quad 0.001$

$8.9 \quad 0.002$

$1.58 \quad 0.004$

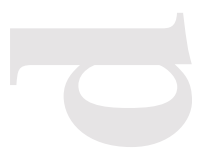

This article is protected by copyright. All rights reserved. 
Table 3. Average Clinopyroxene Compositions

\begin{tabular}{|c|c|c|c|c|c|c|c|c|c|c|c|c|c|c|c|}
\hline Sample No. & $\operatorname{DMTZ}(\mathrm{m})$ & $\mathrm{SiO2}$ & TiO2 & $\mathrm{Al} 2 \mathrm{O} 3$ & $\mathrm{Cr} 2 \mathrm{O} 3$ & FeO total & $\mathrm{MnO}$ & MgO & $\mathrm{CaO}$ & $\mathrm{Na2O}$ & Total & Mg\# & Wo & En & Fs \\
\hline OM97-67a & 46 & 52.64 & 0.49 & 2.84 & 0.44 & 5.63 & 0.11 & 16.17 & 21.35 & 0.26 & 99.93 & 0.84 & 0.44 & 0.47 & 0.09 \\
\hline OM97-63 & 119 & 53.66 & 0.38 & 2.73 & 0.21 & 4.29 & 0.13 & 17.33 & 21.53 & 0.22 & 100.48 & 0.88 & 0.44 & 0.49 & 0.07 \\
\hline OM97-70 & 135 & 52.65 & 0.52 & 2.71 & 0.17 & 5.30 & 0.15 & 16.63 & 21.15 & 0.26 & 99.56 & 0.85 & 0.44 & 0.48 & 0.09 \\
\hline OM97-45 & 162 & 52.56 & 0.49 & 2.69 & 0.26 & 5.53 & 0.12 & 16.58 & 20.96 & 0.25 & 99.44 & 0.84 & 0.43 & 0.48 & 0.09 \\
\hline OM97-52 & 525 & 51.50 & 0.61 & 2.82 & 0.15 & 7.42 & 0.22 & 15.64 & 20.76 & 0.33 & 99.45 & 0.79 & 0.43 & 0.45 & 0.12 \\
\hline OM97-59a & 640 & 51.79 & 0.57 & 3.10 & 0.14 & 6.35 & 0.13 & 15.62 & 21.31 & 0.25 & 99.27 & 0.81 & 0.44 & 0.45 & 0.10 \\
\hline OM97-75 & 719 & 52.11 & 0.60 & 2.78 & 0.05 & 6.77 & 0.12 & 15.59 & 21.16 & 0.30 & 99.49 & 0.80 & 0.44 & 0.45 & 0.11 \\
\hline OM99-40 & 961 & 51.81 & 0.39 & 2.53 & 0.30 & 6.66 & 0.17 & 16.67 & 21.16 & 0.34 & 100.03 & 0.82 & 0.43 & 0.47 & 0.10 \\
\hline OM99-44 & 1253 & 52.03 & 0.46 & 2.50 & 0.17 & 6.46 & 0.15 & 16.72 & 21.41 & 0.25 & 100.15 & 0.82 & 0.43 & 0.47 & 0.10 \\
\hline OM99-47 & 1392 & 52.60 & 0.42 & 2.29 & 0.15 & 5.57 & 0.16 & 17.61 & 21.47 & 0.28 & 100.56 & 0.85 & 0.43 & 0.49 & 0.86 \\
\hline OM99-51 & 1535 & 52.68 & 0.39 & 2.40 & 0.27 & 4.36 & 0.09 & 17.76 & 22.39 & 0.26 & 100.59 & 0.88 & 0.44 & 0.49 & 0.67 \\
\hline OM97-84 & 1663 & 52.88 & 0.57 & 2.53 & 0.13 & 6.68 & 0.13 & 16.28 & 21.32 & 0.29 & 100.80 & 0.81 & 0.43 & 0.46 & 0.11 \\
\hline OM97-89 & 1793 & 53.08 & 0.38 & 2.45 & 0.25 & 4.75 & 0.12 & 16.86 & 21.44 & 0.29 & 99.61 & 0.86 & 0.44 & 0.48 & 0.08 \\
\hline OM97-94a & 2011 & 52.76 & 0.41 & 2.41 & 0.22 & 5.64 & 0.10 & 16.51 & 21.27 & 0.24 & 99.57 & 0.84 & 0.44 & 0.47 & 0.09 \\
\hline OM97-200 & 2181 & 53.43 & 0.47 & 2.27 & 0.09 & 5.41 & 0.15 & 17.22 & 21.20 & 0.24 & 100.47 & 0.85 & 0.43 & 0.49 & 0.09 \\
\hline OM97-99 & 2193 & 52.19 & 0.62 & 2.48 & 0.08 & 6.65 & 0.14 & 15.93 & 21.39 & 0.26 & 99.74 & 0.81 & 0.44 & 0.45 & 0.11 \\
\hline OM97-97a & 2257 & 51.98 & 0.53 & 2.41 & 0.13 & 6.42 & 0.17 & 17.33 & 20.14 & 0.23 & 99.34 & 0.83 & 0.41 & 0.49 & 0.10 \\
\hline OM97-95 & 2303 & 53.07 & 0.51 & 2.46 & 0.10 & 5.53 & 0.12 & 16.65 & 22.02 & 0.23 & 100.69 & 0.84 & 0.44 & 0.47 & 0.09 \\
\hline OM97-102a & 2369 & 52.67 & 0.57 & 2.63 & 0.31 & 6.00 & 0.12 & 15.80 & 21.29 & 0.31 & 99.70 & 0.82 & 0.44 & 0.46 & 0.10 \\
\hline OM97-104 & 2999 & 51.80 & 0.54 & 2.97 & 0.35 & 6.05 & 0.11 & 15.65 & 21.12 & 0.25 & 98.84 & 0.82 & 0.44 & 0.46 & 0.10 \\
\hline OM97-106 & 3260 & 52.42 & 0.81 & 2.70 & 0.24 & 6.91 & 0.18 & 15.61 & 20.64 & 0.41 & 99.91 & 0.80 & 0.43 & 0.45 & 0.11 \\
\hline OM97-204 & 3573 & 52.28 & 0.45 & 2.45 & 0.23 & 4.96 & 0.13 & 16.68 & 21.57 & 0.25 & 99.01 & 0.86 & 0.44 & 0.48 & 0.08 \\
\hline OM97-111 & 3594 & 52.27 & 0.54 & 2.28 & 0.15 & 6.04 & 0.15 & 16.30 & 21.43 & 0.27 & 99.42 & 0.83 & 0.44 & 0.46 & 0.10 \\
\hline OM97-110 & 3627 & 52.03 & 0.51 & 2.60 & 0.38 & 5.40 & 0.18 & 16.70 & 21.00 & 0.30 & 99.09 & 0.85 & 0.43 & 0.48 & 0.09 \\
\hline OM97-108 & 3632 & 53.15 & 0.48 & 2.70 & 0.44 & 4.77 & 0.11 & 16.93 & 21.78 & 0.25 & 100.60 & 0.86 & 0.44 & 0.48 & 0.08 \\
\hline OM97-112 & 3691 & 53.09 & 0.52 & 2.72 & 0.46 & 5.14 & 0.15 & 16.61 & 21.75 & 0.26 & 100.70 & 0.85 & 0.45 & 0.47 & 0.08 \\
\hline OM97-113 & 3989 & 52.97 & 0.53 & 2.30 & 0.15 & 5.69 & 0.18 & 16.41 & 21.57 & 0.25 & 100.05 & 0.84 & 0.44 & 0.47 & 0.09 \\
\hline OM97-114 & 4367 & 52.14 & 0.47 & 2.40 & 0.19 & 6.08 & 0.17 & 16.66 & 21.13 & 0.24 & 99.47 & 0.83 & 0.43 & 0.47 & 0.10 \\
\hline OM97-207 & 4468 & 53.93 & 0.06 & 0.24 & 0.02 & 9.06 & 0.37 & 13.68 & 23.09 & 0.13 & 100.57 & 0.73 & 0.47 & 0.39 & 0.14 \\
\hline OM97-209 & 4680 & 51.48 & 0.66 & 2.65 & 0.04 & 7.89 & 0.22 & 15.66 & 20.83 & 0.28 & 99.70 & 0.78 & 0.43 & 0.45 & 0.13 \\
\hline
\end{tabular}

This article is protected by copyright. All rights reserved. 
Table 4. Average Olivine Composition

\begin{tabular}{|c|c|c|c|c|c|c|c|c|}
\hline Sample ID & $\operatorname{DMTZ}(\mathrm{m})$ & $\mathrm{SiO} 2$ & FeO total & $\mathrm{MnO}$ & MgO & $\mathrm{CaO}$ & Total & Fo \\
\hline OM97-67a & 46 & 39.31 & 18.65 & 0.32 & 41.58 & 0.03 & 100.14 & 79.9 \\
\hline OM97-63 & 119 & n.a. & n.a. & n.a. & n.a. & n.a. & n.a. & n.a. \\
\hline OM97-70 & 135 & 38.74 & 17.81 & 0.26 & 42.13 & 0.03 & 99.05 & 80.8 \\
\hline OM97-45 & 162 & 39.17 & 18.39 & 0.30 & 42.39 & 0.03 & 100.45 & 80.4 \\
\hline OM97-52 & 525 & 37.48 & 23.03 & 0.33 & 38.40 & 0.06 & 99.41 & 74.8 \\
\hline OM97-59a & 640 & 38.74 & 20.67 & 0.35 & 40.20 & 0.08 & 100.18 & 77.6 \\
\hline OM97-75 & 719 & 37.94 & 22.98 & 0.36 & 38.45 & 0.05 & 99.92 & 74.9 \\
\hline OM99-40 & 961 & 37.92 & 22.18 & 0.29 & 39.91 & 0.08 & 100.49 & 76.2 \\
\hline OM99-43 & 961 & n.a. & n.a. & n.a. & n.a. & n.a. & n.a. & n.a. \\
\hline OM99-44 & 1253 & 38.27 & 21.10 & 0.31 & 41.00 & 0.06 & 100.81 & 77.6 \\
\hline OM99-47 & 1392 & 38.82 & 18.29 & 0.24 & 43.01 & 0.05 & 100.54 & 80.7 \\
\hline OM99-49 & 1392 & n.a. & n.a. & n.a. & n.a. & n.a. & n.a. & n.a. \\
\hline OM99-51 & 1535 & 39.45 & 14.73 & 0.23 & 46.00 & 0.03 & 100.61 & 84.8 \\
\hline OM99-53 & 1535 & n.a. & n.a. & n.a. & n.a. & n.a. & n.a. & n.a. \\
\hline OM97-84 & 1663 & n.a. & n.a. & n.a. & n.a. & n.a. & n.a. & n.a. \\
\hline OM97-89 & 1793 & 38.53 & 18.91 & 0.26 & 41.39 & 0.04 & 99.28 & 79.6 \\
\hline OM97-94a & 2011 & 38.33 & 19.55 & 0.35 & 40.91 & 0.04 & 99.35 & 78.9 \\
\hline OM97-200 & 2181 & 39.05 & 17.64 & 0.27 & 43.00 & 0.05 & 100.19 & 81.3 \\
\hline OM97-99 & 2193 & 37.89 & 22.77 & 0.37 & 38.36 & 0.06 & 99.64 & 75.0 \\
\hline OM97-97a & 2257 & 38.19 & 20.58 & 0.30 & 40.23 & 0.07 & 99.47 & 77.7 \\
\hline OM97-95 & 2303 & 38.49 & 18.89 & 0.27 & 41.72 & 0.05 & 99.57 & 79.7 \\
\hline OM97-102a & 2369 & 38.63 & 20.70 & 0.37 & 39.65 & 0.05 & 99.61 & 77.3 \\
\hline OM97-104 & 2999 & 38.26 & 20.62 & 0.37 & 39.69 & 0.04 & 99.19 & 77.4 \\
\hline OM97-106 & 3260 & 37.99 & 22.54 & 0.25 & 37.77 & 0.06 & 98.86 & 74.9 \\
\hline OM97-204 & 3573 & 38.43 & 17.05 & 0.25 & 42.78 & 0.04 & 98.72 & 81.7 \\
\hline OM97-111 & 3594 & 38.10 & 21.31 & 0.30 & 39.61 & 0.05 & 99.55 & 76.8 \\
\hline OM97-110 & 3627 & 38.18 & 19.79 & 0.26 & 41.04 & 0.04 & 99.46 & 78.7 \\
\hline OM97-108 & 3632 & 38.77 & 18.53 & 0.30 & 42.27 & 0.05 & 100.07 & 80.3 \\
\hline OM97-112 & 3691 & 38.00 & 18.49 & 0.23 & 41.78 & 0.05 & 98.77 & 80.1 \\
\hline OM97-113 & 3989 & - & - & - & - & - & - & - \\
\hline OM97-114 & 4367 & - & - & - & - & - & - & - \\
\hline OM97-207 & 4468 & - & - & - & - & - & - & - \\
\hline OM97-209 & 4680 & - & - & - & - & - & - & - \\
\hline
\end{tabular}

n.a. = not analyzed

- = no cumulus olivine present 
Table 5. Average Plagioclase Compositions

\begin{tabular}{|c|c|c|c|c|c|c|c|}
\hline Sample ID & $\mathrm{DMTZ}(\mathrm{m})$ & $\mathrm{SiO} 2$ & Al2O3 & $\mathrm{FeO}$ & $\mathrm{CaO}$ & $\mathrm{Na} 2 \mathrm{O}$ & $\mathrm{K} 2 \mathrm{O}$ \\
\hline OM97-67a & 46 & 47.56 & 33.75 & 0.42 & 16.58 & 1.97 & 0.01 \\
\hline OM97-63 & 119 & 45.90 & 34.26 & 0.35 & 17.17 & 1.50 & 0.01 \\
\hline OM97-70 & 135 & 46.46 & 33.75 & 0.43 & 16.54 & 1.78 & 0.01 \\
\hline OM97-45 & 162 & 47.49 & 33.94 & 0.43 & 16.61 & 2.00 & 0.02 \\
\hline OM97-52 & 525 & 48.97 & 32.17 & 0.55 & 14.83 & 2.81 & 0.02 \\
\hline OM97-59a & 640 & 46.32 & 34.10 & 0.55 & 17.24 & 1.52 & 0.01 \\
\hline OM97-75 & 719 & 47.22 & 33.49 & 0.55 & 16.43 & 1.96 & 0.00 \\
\hline OM99-40 & 961 & 48.07 & 33.08 & 0.48 & 16.37 & 2.27 & 0.02 \\
\hline OM99-43 & 961 & n.a. & n.a. & n.a. & n.a. & n.a. & n.a. \\
\hline OM99-44 & 1253 & 47.25 & 33.59 & 0.49 & 16.99 & 1.89 & 0.01 \\
\hline OM99-47 & 1392 & 47.69 & 33.39 & 0.39 & 16.72 & 2.08 & 0.02 \\
\hline OM99-49 & 1392 & n.a. & n.a. & n.a. & n.a. & n.a. & n.a. \\
\hline OM99-51 & 1535 & 46.40 & 34.68 & 0.38 & 17.95 & 1.38 & 0.01 \\
\hline OM99-53 & 1535 & n.a. & n.a. & n.a. & n.a. & n.a. & n.a. \\
\hline OM97-84 & 1663 & 48.11 & 32.99 & 0.49 & 16.44 & 2.25 & 0.01 \\
\hline OM97-89 & 1793 & 46.87 & 33.74 & 0.42 & 16.33 & 1.95 & 0.01 \\
\hline OM97-94a & 2011 & 47.76 & 33.61 & 0.49 & 16.32 & 2.13 & 0.02 \\
\hline OM97-200 & 2181 & 47.63 & 33.91 & 0.40 & 16.85 & 1.86 & 0.02 \\
\hline OM97-99 & 2193 & 46.82 & 34.05 & 0.58 & 17.12 & 1.66 & 0.01 \\
\hline OM97-97a & 2257 & 46.73 & 33.81 & 0.45 & 16.64 & 1.79 & 0.01 \\
\hline OM97-95 & 2303 & 47.07 & 33.71 & 0.41 & 17.04 & 1.89 & 0.01 \\
\hline OM97-102a & 2369 & 47.47 & 33.88 & 0.50 & 16.62 & 1.88 & 0.01 \\
\hline OM97-104 & 2999 & 47.35 & 33.64 & 0.46 & 16.37 & 1.90 & 0.01 \\
\hline OM97-106 & 3260 & 49.96 & 31.81 & 0.45 & 14.37 & 3.12 & 0.03 \\
\hline OM97-204 & 3573 & 46.11 & 33.55 & 0.42 & 16.82 & 1.74 & 0.02 \\
\hline OM97-111 & 3594 & 47.79 & 33.51 & 0.44 & 16.60 & 2.03 & 0.01 \\
\hline OM97-110 & 3627 & 46.83 & 33.41 & 0.37 & 16.24 & 2.05 & 0.01 \\
\hline OM97-108 & 3632 & 47.65 & 33.64 & 0.45 & 16.57 & 2.08 & 0.02 \\
\hline OM97-112 & 3691 & 46.88 & 33.67 & 0.34 & 16.58 & 1.91 & 0.02 \\
\hline OM97-113 & 3989 & 48.64 & 32.40 & 0.44 & 15.20 & 2.67 & 0.08 \\
\hline OM97-114 & 4367 & 48.97 & 32.40 & 0.53 & 14.81 & 2.73 & 0.08 \\
\hline OM97-207 & 4468 & 56.87 & 27.63 & 0.33 & 9.72 & 6.07 & 0.15 \\
\hline OM97-209 & 4680 & 48.14 & 32.98 & 0.49 & 15.70 & 2.28 & 0.04 \\
\hline
\end{tabular}




\begin{tabular}{|cc|}
\hline Total & An \\
\hline 100.32 & 82.31 \\
\hline 99.24 & 86.31 \\
\hline 99.01 & 83.69 \\
\hline 100.53 & 82.07 \\
\hline 99.42 & 74.46 \\
\hline 99.76 & 86.27 \\
\hline 99.69 & 82.22 \\
\hline 100.33 & 79.82 \\
\hline n.a. & n.a. \\
\hline 100.26 & 83.17 \\
\hline 100.35 & 81.55 \\
\hline n.a. & n.a. \\
\hline 100.83 & 87.71 \\
\hline n.a. & n.a. \\
\hline 100.36 & 80.13 \\
\hline 99.36 & 82.26 \\
\hline 100.36 & 80.88 \\
\hline 100.69 & 83.34 \\
\hline 100.32 & 85.05 \\
\hline 99.47 & 83.71 \\
\hline 100.15 & 83.32 \\
\hline 100.37 & 83.02 \\
\hline 99.76 & 82.60 \\
\hline 99.77 & 71.83 \\
\hline 98.69 & 84.26 \\
\hline 100.42 & 81.91 \\
\hline 98.93 & 81.41 \\
\hline 100.42 & 81.50 \\
\hline 99.42 & 82.79 \\
\hline 99.46 & 75.92 \\
\hline 99.57 & 74.99 \\
\hline 99.66 & 46.98 \\
\hline & 79.18 \\
\hline
\end{tabular}

This article is protected by copyright. All rights reserved. 
Table 6. Plagioclase trace elements from LAICPMS

\begin{tabular}{|c|c|c|c|c|c|c|c|c|c|c|c|c|c|c|c|c|c|c|}
\hline Sample No & OM97-67 & ом97-63 & OM97-45 & ом97-59a & ом99-40 & ом99-44 & ом99-47 & OM99-51 & ом97-85 & ом97-89 & ОM97-94а & ом97-95 & ом97-104 & OM97-106 & OM97-204 & OM97-111 & ом97-113 & ом97-114 \\
\hline DMTZ (m) & 46 & 119 & 162 & 640 & 961 & 1253 & 1392 & 1535 & 1663 & 1793 & 2011 & 2303 & 2999 & 3260 & 3573 & 3594 & 3989 & 4367 \\
\hline$(\mathrm{ppm})$ & Mean, $n=21$ & Mean, $n=20$ & Mean, $n=15$ & Mean, $n=20$ & Mean, $n=20$ & Mean, $n=15$ & Mean, $n=17$ & Mean, $n=11$ & Mean, $n=19$ & Mean, $n=17$ & Mean, $\mathrm{n}=18$ & Mean, $n=15$ & Mean, $n=20$ & Mean, $n=20$ & Mean, $n=14$ & Mean, $n=15$ & Mean, $n=14$ & Mean, $n=12$ \\
\hline v & 1.85 & 1.94 & 2.66 & 1.97 & 1.72 & 2.06 & 1.68 & 1.83 & 1.83 & 1.74 & 2.21 & 2.32 & 1.58 & 2.03 & 1.79 & 1.81 & 1.62 & 1.98 \\
\hline co & 0.25 & 0.41 & 0.44 & 0.22 & 0.27 & 0.47 & 0.24 & 0.38 & 0.36 & 0.19 & 0.34 & 0.33 & 0.45 & 0.27 & 0.16 & 0.21 & 0.18 & 0.35 \\
\hline $\mathrm{Zn}$ & 2.15 & 4.28 & 2.53 & 1.93 & 2.16 & 2.10 & 2.02 & 2.24 & 2.38 & 1.84 & 1.59 & 2.00 & 2.25 & 2.21 & 1.45 & 1.97 & 1.83 & 3.02 \\
\hline $\mathrm{Rb}$ & 0.02 & 0.01 & 0.01 & -0.01 & 0.22 & 0.02 & 0.04 & 0.08 & 0.00 & 0.02 & 0.02 & 0.07 & 0.06 & 0.04 & 0.09 & 0.02 & 0.05 & 0.05 \\
\hline $\mathrm{Sr}$ & 224.49 & 201.72 & 257.71 & 274.69 & 275.56 & 271.61 & 218.31 & 186.80 & 257.45 & 232.77 & 249.02 & 255.43 & 225.03 & 276.33 & 219.27 & 276.97 & 223.86 & 225.91 \\
\hline y & 0.16 & 0.08 & 0.15 & 0.13 & 0.19 & 0.15 & 0.17 & 0.10 & 0.16 & 0.20 & 0.17 & 0.17 & 0.13 & 0.22 & 0.22 & 0.18 & 0.63 & 0.32 \\
\hline $\mathrm{Zr}$ & 0.02 & 0.00 & 0.01 & 0.00 & 0.01 & 0.03 & 0.03 & 0.09 & 0.01 & 0.01 & 0.05 & 0.02 & 0.02 & 0.02 & 0.03 & 0.02 & 0.09 & 0.02 \\
\hline $\mathrm{Ba}$ & 4.23 & 2.35 & 5.76 & 3.66 & 5.48 & 4.75 & 4.10 & 4.03 & 4.60 & 4.28 & 4.43 & 4.85 & 5.71 & 6.76 & 5.36 & 5.37 & 8.06 & 4.04 \\
\hline La & 0.20 & 0.10 & 0.20 & 0.16 & 0.19 & 0.20 & 0.18 & 0.14 & 0.19 & 0.22 & 0.20 & 0.22 & 0.24 & 0.39 & 0.31 & 0.30 & 0.40 & 0.18 \\
\hline $\mathrm{Ce}$ & 0.37 & 0.22 & 0.41 & 0.35 & 0.37 & 0.40 & 0.38 & 0.31 & 0.38 & 0.42 & 0.43 & 0.46 & 0.50 & 0.76 & 0.64 & 0.59 & 0.84 & 0.39 \\
\hline $\operatorname{Pr}$ & 0.06 & 0.03 & 0.05 & 0.05 & 0.06 & 0.06 & 0.05 & 0.04 & 0.06 & 0.07 & 0.06 & 0.06 & 0.06 & 0.11 & 0.08 & 0.08 & 0.14 & 0.06 \\
\hline $\mathrm{Nd}$ & 0.27 & 0.17 & 0.28 & 0.24 & 0.28 & 0.27 & 0.29 & 0.21 & 0.33 & 0.32 & 0.29 & 0.30 & 0.34 & 0.48 & 0.43 & 0.36 & 0.65 & 0.34 \\
\hline $\mathrm{Sm}$ & 0.06 & 0.05 & 0.06 & 0.06 & 0.07 & 0.06 & 0.07 & 0.04 & 0.08 & 0.07 & 0.06 & 0.06 & 0.06 & 0.08 & 0.09 & 0.08 & 0.17 & 0.08 \\
\hline $\mathrm{Eu}$ & 0.24 & 0.14 & 0.23 & 0.18 & 0.24 & 0.24 & 0.23 & 0.16 & 0.23 & 0.27 & 0.22 & 0.24 & 0.24 & 0.36 & 0.24 & 0.30 & 0.41 & 0.27 \\
\hline $\mathrm{Gd}$ & 0.06 & 0.02 & 0.05 & 0.04 & 0.07 & 0.05 & 0.06 & 0.04 & 0.07 & 0.07 & 0.07 & 0.06 & 0.06 & 0.09 & 0.08 & 0.07 & 0.16 & 0.09 \\
\hline $\mathrm{Tb}$ & 0.01 & 0.00 & 0.01 & 0.01 & 0.01 & 0.01 & 0.01 & 0.00 & 0.01 & 0.01 & 0.01 & 0.01 & 0.01 & 0.01 & 0.01 & 0.01 & 0.02 & 0.01 \\
\hline Dy & 0.04 & 0.02 & 0.03 & 0.04 & 0.04 & 0.04 & 0.04 & 0.03 & 0.04 & 0.05 & 0.04 & 0.04 & 0.03 & 0.05 & 0.05 & 0.04 & 0.13 & 0.06 \\
\hline Ho & 0.01 & 0.00 & 0.01 & 0.01 & 0.01 & 0.01 & 0.01 & 0.00 & 0.01 & 0.01 & 0.00 & 0.01 & 0.00 & 0.01 & 0.01 & 0.01 & 0.03 & 0.01 \\
\hline Er & 0.02 & 0.01 & 0.01 & 0.01 & 0.02 & 0.01 & 0.01 & 0.01 & 0.01 & 0.02 & 0.02 & 0.01 & 0.01 & 0.02 & 0.02 & 0.01 & 0.06 & 0.04 \\
\hline $\mathrm{Tm}$ & 0.00 & 0.00 & 0.00 & 0.00 & 0.00 & 0.00 & 0.00 & 0.00 & 0.00 & 0.00 & 0.00 & 0.00 & 0.00 & 0.00 & 0.00 & 0.00 & 0.01 & 0.01 \\
\hline $\mathrm{Yb}$ & 0.01 & 0.01 & 0.01 & 0.01 & 0.01 & 0.01 & 0.01 & 0.01 & 0.01 & 0.01 & 0.01 & 0.01 & 0.01 & 0.01 & 0.01 & 0.01 & 0.03 & 0.02 \\
\hline Lu & 0.00 & 0.00 & 0.00 & 0.00 & 0.00 & 0.00 & 0.00 & 0.00 & 0.00 & 0.00 & 0.00 & 0.00 & 0.00 & 0.00 & 0.00 & 0.00 & 0.00 & 0.00 \\
\hline $\mathrm{Pb}$ & 0.06 & 0.04 & 0.09 & 0.03 & 0.11 & 0.12 & 0.04 & 0.18 & 0.05 & 0.04 & 0.06 & 0.06 & 0.15 & 0.10 & 0.07 & 0.11 & 0.26 & 0.11 \\
\hline Th & 0.00 & 0.00 & 0.00 & 0.00 & 0.00 & 0.00 & 0.00 & 0.00 & 0.00 & 0.00 & 0.00 & 0.00 & 0.00 & 0.00 & 0.00 & 0.00 & 0.00 & 0.00 \\
\hline
\end{tabular}

This article is protected by copyright. All rights reserved. 
Table 7. Average Clinopyroxene trace elements by LAICPMS

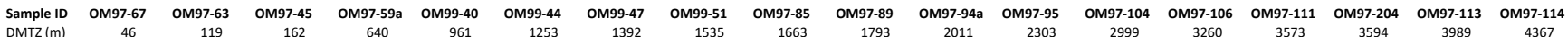
\#Analyses Mean, $\mathrm{n}=20$ Mean, $\mathrm{n}=20$ Mean, $\mathrm{n}=16$ Mean, $\mathrm{n}=19$ Mean, $\mathrm{n}=18$ Mean, $\mathrm{n}=15$ Mean, $\mathrm{n}=18$ Mean, $\mathrm{n}=18$ Mean, $\mathrm{n}=19$ Mean, $\mathrm{n}=21$ Mean, $\mathrm{n}=12$ Mean, $\mathrm{n}=16 \quad$ Mean, $\mathrm{n}=10$ Mean, $\mathrm{n}=18$ Mean, $\mathrm{n}=17 \quad$ Mean, $\mathrm{n}=20$ Mean, $\mathrm{n}=12$ Mean, $\mathrm{n}=7$

\begin{tabular}{|c|c|c|c|c|c|c|c|c|c|c|c|c|c|c|c|c|c|c|}
\hline Sc & 108.64 & n.a. & 101.43 & 99.77 & 106.20 & 102.85 & 107.95 & 97.39 & 108.21 & 99.43 & 100.20 & 101.47 & 108.11 & 117.21 & 105.42 & 101.56 & 108.32 & 103.97 \\
\hline v & 295.84 & 276.45 & 315.64 & 339.30 & 304.86 & 315.70 & 304.27 & 260.05 & 341.26 & 239.79 & 289.11 & 249.93 & 276.20 & 417.66 & 319.89 & 285.94 & 320.34 & 290.24 \\
\hline $\mathrm{Cr}$ & 3038.94 & n.a. & 1362.04 & 1966.85 & 2096.78 & 972.74 & 818.85 & 1612.18 & 693.99 & 2225.76 & 1397.63 & 2046.10 & 2561.85 & 1294.40 & 1090.74 & 1434.39 & 2018.65 & 1222.02 \\
\hline Co & 38.56 & 34.97 & 40.61 & 37.77 & 46.58 & 41.23 & 39.25 & 33.87 & 40.56 & 34.48 & 39.73 & 34.56 & 35.18 & 40.82 & 37.88 & 36.26 & 37.78 & 38.53 \\
\hline $\mathrm{Ni}$ & n.a. & 202.58 & 137.41 & 112.64 & n.a. & 82.96 & 97.34 & 174.70 & 114.45 & n.a. & 147.50 & 107.24 & 119.47 & 131.84 & 104.61 & 133.81 & n.a. & 108.97 \\
\hline $\mathrm{Cu}$ & 2.66 & n.a. & 0.20 & 0.90 & 0.89 & 0.38 & 0.37 & 1.76 & 0.49 & 0.96 & 0.41 & 0.31 & 0.82 & 0.40 & 0.26 & 0.25 & 0.85 & 0.24 \\
\hline $\mathrm{Zn}$ & 25.02 & 16.52 & 23.47 & 23.61 & 26.86 & 29.31 & 25.47 & 18.80 & 28.21 & 19.65 & 23.70 & 21.54 & 25.59 & 36.02 & 30.20 & 21.42 & 30.07 & 23.50 \\
\hline $\mathrm{Sr}$ & 10.69 & 10.39 & 11.05 & 11.85 & 10.00 & 10.41 & 9.92 & 8.50 & 11.33 & 9.83 & 8.71 & 9.27 & 8.58 & 10.48 & 10.64 & 10.06 & 8.76 & 9.99 \\
\hline Y & 9.55 & 7.65 & 10.76 & 9.70 & 10.86 & 11.18 & 11.12 & 7.36 & 12.38 & 7.15 & 9.13 & 8.05 & 11.08 & 18.49 & 12.36 & 10.40 & 13.75 & 9.15 \\
\hline $\mathrm{Zr}$ & 6.50 & 4.10 & 5.97 & 6.38 & 6.27 & 6.54 & 6.09 & 5.17 & 7.19 & 4.13 & 6.46 & 5.97 & 9.06 & 15.53 & 9.17 & 7.19 & 10.23 & 5.00 \\
\hline $\mathrm{Nb}$ & 0.01 & 0.00 & 0.01 & 0.01 & 0.04 & 0.01 & 0.01 & 0.01 & 0.01 & 0.01 & 0.02 & 0.01 & 0.02 & 0.03 & 0.02 & 0.02 & 0.01 & 0.01 \\
\hline $\mathrm{Ba}$ & 0.00 & 0.01 & 0.01 & 0.01 & 0.21 & 0.05 & 0.02 & 0.01 & 0.01 & 0.01 & 0.04 & 0.01 & 0.09 & 0.02 & 0.03 & 0.01 & 0.01 & 0.01 \\
\hline La & 0.15 & 0.11 & 0.18 & 0.16 & 0.16 & 0.16 & 0.14 & 0.12 & 0.18 & 0.11 & 0.16 & 0.15 & 0.20 & 0.32 & 0.22 & 0.20 & 0.28 & 0.13 \\
\hline $\mathrm{Ce}$ & 0.88 & 0.58 & 0.94 & 0.93 & 0.87 & 0.91 & 0.81 & 0.67 & 0.99 & 0.59 & 0.89 & 0.79 & 1.02 & 1.92 & 1.23 & 1.04 & 1.42 & 0.73 \\
\hline $\mathrm{Pr}$ & 0.22 & 0.14 & 0.23 & 0.23 & 0.22 & 0.23 & 0.21 & 0.16 & 0.25 & 0.15 & 0.21 & 0.20 & 0.25 & 0.46 & 0.30 & 0.25 & 0.35 & 0.19 \\
\hline $\mathrm{Nd}$ & 1.61 & 1.23 & 1.78 & 1.76 & 1.66 & 1.88 & 1.73 & 1.17 & 2.04 & 1.10 & 1.67 & 1.50 & 1.96 & 3.52 & 2.29 & 1.87 & 2.39 & 1.48 \\
\hline Sm & 0.88 & 0.65 & 0.98 & 0.93 & 0.95 & 0.97 & 0.92 & 0.64 & 1.12 & 0.63 & 0.86 & 0.80 & 1.00 & 1.73 & 1.18 & 0.96 & 1.29 & 0.78 \\
\hline $\mathrm{Eu}$ & 0.35 & 0.28 & 0.41 & 0.42 & 0.39 & 0.42 & 0.39 & 0.29 & 0.47 & 0.26 & 0.36 & 0.32 & 0.42 & 0.68 & 0.47 & 0.39 & 0.42 & 0.35 \\
\hline $\mathrm{Gd}$ & 1.46 & 1.06 & 1.54 & 1.42 & 1.68 & 1.57 & 1.51 & 1.03 & 1.81 & 1.11 & 1.28 & 1.21 & 1.60 & 2.70 & 1.80 & 1.51 & 2.06 & 1.32 \\
\hline Tb & 0.27 & 0.21 & 0.30 & 0.28 & 0.29 & 0.31 & 0.30 & 0.20 & 0.35 & 0.19 & 0.26 & 0.24 & 0.31 & 0.54 & 0.36 & 0.29 & 0.39 & 0.27 \\
\hline Dy & 1.88 & 1.48 & 2.06 & 1.87 & 2.07 & 2.13 & 2.15 & 1.43 & 2.42 & 1.37 & 1.77 & 1.58 & 2.17 & 3.58 & 2.39 & 2.02 & 2.64 & 1.84 \\
\hline Ho & 0.39 & 0.30 & 0.45 & 0.40 & 0.44 & 0.45 & 0.44 & 0.31 & 0.52 & 0.30 & 0.38 & 0.33 & 0.45 & 0.78 & 0.51 & 0.43 & 0.57 & 0.38 \\
\hline Er & 1.11 & 0.85 & 1.19 & 1.04 & 1.24 & 1.23 & 1.22 & 0.78 & 1.37 & 0.83 & 0.99 & 0.89 & 1.25 & 2.01 & 1.35 & 1.15 & 1.60 & 1.00 \\
\hline $\mathrm{Tm}$ & 0.15 & 0.11 & 0.16 & 0.14 & 0.17 & 0.17 & 0.17 & 0.11 & 0.19 & 0.11 & 0.14 & 0.12 & 0.17 & 0.27 & 0.19 & 0.16 & 0.22 & 0.14 \\
\hline $\mathrm{Yb}$ & 0.94 & 0.78 & 1.08 & 0.98 & 1.04 & 1.15 & 1.11 & 0.74 & 1.27 & 0.70 & 0.92 & 0.80 & 1.15 & 1.91 & 1.27 & 1.08 & 1.39 & 0.90 \\
\hline Lu & 0.13 & 0.11 & 0.15 & 0.13 & 0.15 & 0.16 & 0.15 & 0.10 & 0.17 & 0.10 & 0.12 & 0.11 & 0.16 & 0.26 & 0.18 & 0.15 & 0.20 & 0.13 \\
\hline $\mathrm{Hf}$ & 0.33 & 0.23 & 0.31 & 0.34 & 0.32 & 0.34 & 0.31 & 0.24 & 0.38 & 0.23 & 0.34 & 0.32 & 0.44 & 0.76 & 0.45 & 0.34 & 0.47 & 0.26 \\
\hline $\mathrm{Pb}$ & 0.01 & 0.01 & 0.02 & 0.01 & 0.00 & 0.01 & 0.01 & 0.01 & 0.00 & 0.01 & 0.00 & 0.01 & 0.14 & 0.02 & 0.02 & 0.01 & 0.02 & 0.02 \\
\hline Th & 0.00 & 0.00 & 0.00 & 0.00 & 0.01 & 0.00 & 0.00 & 0.00 & 0.00 & 0.00 & 0.00 & 0.00 & 0.00 & 0.00 & 0.00 & 0.00 & 0.02 & 0.00 \\
\hline u & 0.00 & 0.00 & 0.00 & 0.00 & 0.00 & 0.00 & 0.00 & 0.00 & 0.00 & 0.00 & 0.00 & 0.00 & 0.00 & 0.00 & 0.00 & 0.00 & 0.01 & 0.00 \\
\hline
\end{tabular}
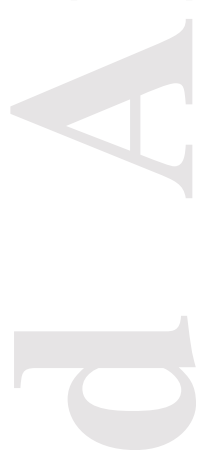

This article is protected by copyright. All rights reserved. 
Table 8. Equilibrium liquid calculated from clinopyroxene $\mathrm{D}$ and olivine $\mathrm{Fe} / \mathrm{Mg} \mathrm{Kd}$

$\begin{array}{ccccccccccccccc}\text { Sample Number } & \text { OM97-67 } & \text { OM97-63 } & \text { OM97-70 } & \text { OM97-45 } & \text { OM97-52 } & \text { OM97-59a } & \text { OM97-75 } & \text { OM99-40 } & \text { OM99-44 } & \text { OM99-47 } & \text { OM99-51 } & \text { OM97-85 } & \text { OM97-89 } \\ \text { DMTZ (m) } & 46 & 119 & 135 & 162 & 525 & 640 & 719 & 961 & 1253 & 1392 & 1535 & 1663 & 1793\end{array}$

Calculated Equilibrium liquid from olivine

$0.79 \quad 0.81$

1.12

0.96

1.12

1.04

0.96

0.80

0.60

n.a.

0.85

n.a. $=$ not analyzed
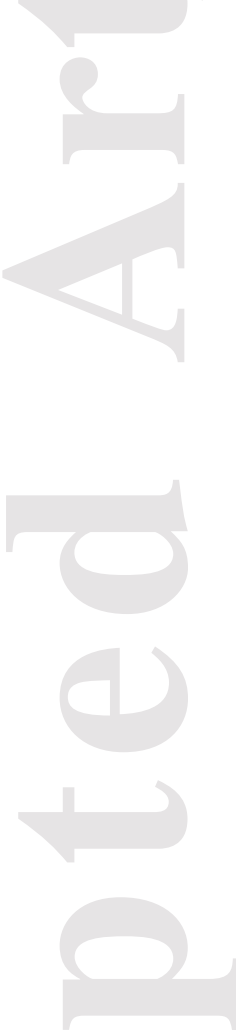

This article is protected by copyright. All rights reserved. 


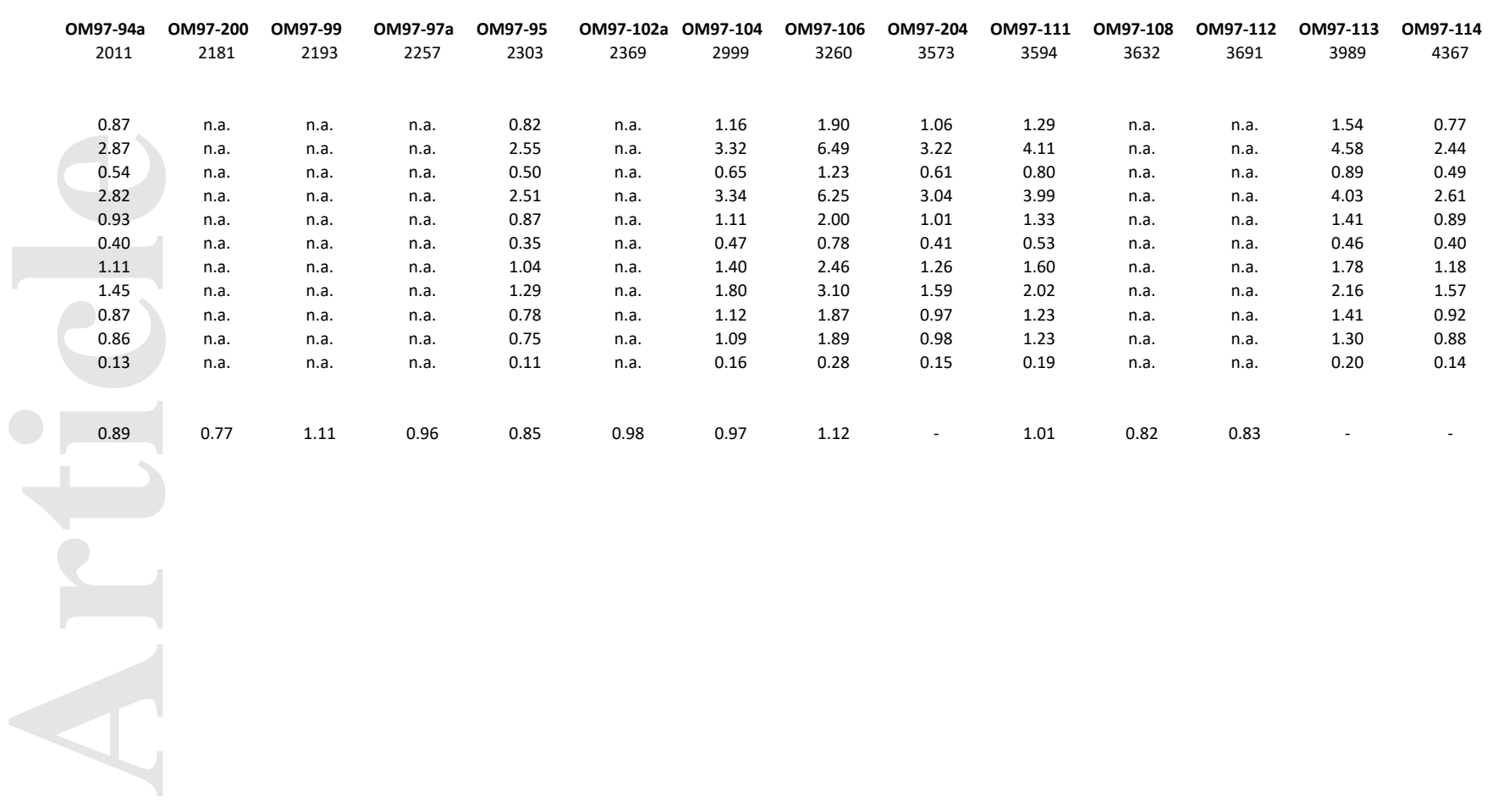

This article is protected by copyright. All rights reserved. 
Table 9. Bulk composition of Khafifah lower crust

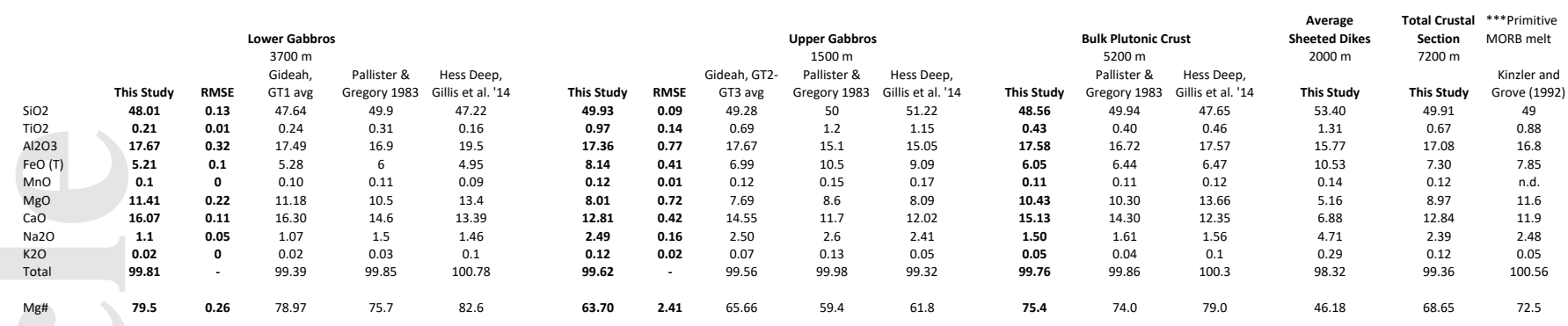

* Gillis et al. (2014) lower gabbro composition for the layered series only

**Pallister and Gregory (1983) estimate of upper gabbros includes $0.1 \%$ plagiogranite

$* * * 14 \%$ aggregated fractional melting of the mantle, from Kinzler and Grove (1992)
RMSE calculations for the lower and upper gabbros can be found in Supplementary Table

Upper gabbros composition in this study includes $500 \mathrm{~m}$ of high-level gabbros and $0.1 \%(5.2 \mathrm{~m}$ ) plagiogranite from estimates of Pallister and Gregory (1983)

Gideah, GT1 avg is the average of all gabbros measured in the ICDP drillcore GT1 through the lower gabbros in Wadi Gideah. Data from Kelemen et al. 2020a
Gideah, GT2-GT3 avg is the average of 5 foliated gabbro samples from the uppermost $50 \mathrm{~m}$ of the GT2 drillcore and 38 high-level gabbros and diorites from the lowermost section of the GT3 drillcore. Data from Kelemen et al. 2020b,
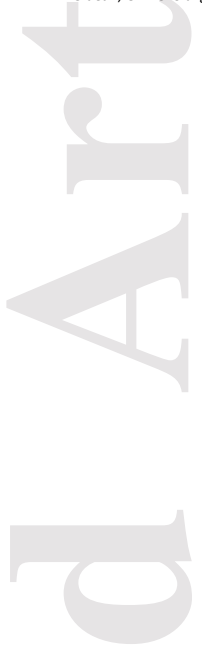

This article is protected by copyright. All rights reserved. 